\title{
VEDó Attila \\ A Magyar Királyi Csendőrség teendői a külföldiek ellenőrzésének szabály- és szervezetrendszerében 1881-1938
}

M inden történelmi korban megjelent az igény arra, hogy az állam kinyilvánítsa szuverenitását, fizikailag körülhatárolja területét és az e területre belépő személyek felett valamilyen ellenőrzést gyakoroljon. Az államok - saját polgáraiktól megkülönböztetendő - idegennek tekintették azokat, akikre szuverenitásuk hatálya a területükön való tartózkodás tényéből adódóan terjedt ki. Az állam polgárai ezzel szemben az állami szuverenitás személyi hatálya alatt álltak és közjogi kötelezettségekből, valamint státuszjogokból álló, a történelmi korszakhoz igazodó tartalmú közjogi státusszal bírtak, amely megkülönböztette őket az idege-nektöl. ${ }^{1}$

Idegenek csak az állam tudtával és beleegyezésével léphettek be a területre és ott csak a nekik engedélyezett tevékenységeket végezhették. Az ókortól kezdve számos példa akad arra vonatkozóan, hogy bizonyos néphez tartozó személyek nem léphettek be vagy például nem kereskedhettek egyes államok területén. A fentiekből is következik, hogy az idegenek (mai értelemben vett külföldiek) ${ }^{2}$ határátlépésére vonatkozó szabályok nem választhatóak el élesen a tartózkodásukra vonatkozó szabályoktól, vagyis a határrendészet az idegenrendészettől. ${ }^{3}$ E két fogalom összefüggéseinek vizsgálatával szükséges bevezetni a feldolgozott témát.

Az idegenrendészet azoknak a szabályoknak az összessége, amely az adott állam jogszabályban rögzített állásfoglalását fejezi ki a vele állampolgársági kapcsolatban nem álló, de különböző társadalmi viszonyokban vele érintkezésbe került személyek helyzete kapcsán. Erről akkor beszélhetünk, amikor az állam belső rendjének, biztonságának, gazdasági rendjének védelme a külföldiek beutazásával és tartózkodásával összefüggésben merül fel, és magában foglalja a határátlépéssel, illetve a belföldön tartózkodással kapcsolatos jogokat és kötelezettségeket, az eljáró hatóságok feladat- és hatáskörét, szervezeti rendszerét, valamint az idegenrendészeti eljárások rendjét. ${ }^{4}$

Összességében tehát az idegenrendészet a külföldiek határátlépésére és beutazására, belföldi tartózkodására, jogaik gyakorlására és ellenőrzésére, szankciók esetleges alkalmazására, és kiutazásukra vonatkozó hatósági jogalkalmazás. ${ }^{5}$

A határrendészetet ezzel szemben úgy tekinthetjük, mint a fentiek érvényre juttatása érdekében rendészeti eszközökkel megvalósított hatósági tevékenység, amely a rendelkezésére álló erőforrások felhasználásával a határbiztonság fenntartására törekszik. Mai értelmezésünk szerint a határrendészet a rendészet része, jogszabályokban és nemzetközi szerződésekben meghatározott jogi norma-, feladat- és eljárásrendszer, amely az arra feljogosított állami és önkormányzati szervek tevékenysége révén a határrend megteremtésére és fenntartására, szükség esetén védelmére irányul. ${ }^{6} \mathrm{~A}$ jelenkor terminológiája szerint határőrzésből és határforgalom-ellenőrzésből álló tevékenység ${ }^{7}$ tehát már a határátlépéskor igyekszik megakadályozni a beutazási feltételeket nem teljesítő személyek belépését, egyúttal ellenőrzött keretek között biztosítja a jogszerüen érkezők beutazását.

Magyarországon a külföldiek ellenőrzésének fenti elvek szerinti rendszere a dualizmus időszakában alakult ki és saját korában európai színvonalon, hatékonyan, a jelentkező kockázatokhoz igazodó intenzitással müködött. A kiegyezéstől a második világháború kitöréséig beszélhetünk arról a történelmi időszakról, amikor a magyar idegenrendészet önálló fejlődési pályát leírva lefektette azokat az elveket, melyek - jelenleg az uniós jog szabályrendszerével történt harmonizációt követően - máig hatnak a külföldiek rendészeti ellenőrzésében. A téma vizsgálata 1867-től kezdődik, mivel a polgári magyar állam életében ettől az időponttól következett be az a viszonylagos belpolitikai önállóság, amely a következő évtizedek jelentős gazdasági fejlődését lehetővé tette. Az osztrák-magyar kiegyezés egyértelmü következménye volt az idegenrendészet átalakulása is. A téma szempontjából a korszak végének a második világháború kitörését tekintem, mivel a háborús események torzították a magyar állam 
külföldiek rendészetével kapcsolatos igényeit és céljait. Az idegenrendészeti szabályrendszeren kívül esőnek tekintem az egyes népcsoportok hátrányos megkülönböztetése érdekében hozott intézkedéseket annál is inkább, mivel azok többségükben a saját állampolgárok meghatározott körére vonatkoztak.

A magyarországi tanácsköztársaság időszakának jogalkotása és idegenrendészeti rendszere szintén kívül esik a tanulmány keretein, mivel az sem terjedelmében, sem szellemiségében nem képez egységes ellenőrző rendszert és bár alapelvei között szerepel az egyenlőség és menedék-nyújtás, az csak politikai feltételekkel volt elérhető mindenki számára. Éppen ezért a tanulmány szempontjából a fenti szabály- és szervezetrendszert a magyar hagyományoktól idegenként kezelem és ismertetésüktől eltekintek.

Tanulmányom célja tehát azoknak a jogszabályoknak a bemutatása, melyek a tárgyalt korszakban meghatározták a külföldiek Magyarországra történő beutazásának és itt tartózkodásának feltételeit, a külföldiek jogait és kötelességeit, valamint az e szabályok betartásának ellenőrzésére hivatott közigazgatási szervezetek, hatóságok és fegyveres testületek feladatait és együttmüködését. Írásomnak nem célja valamennyi részletszabály tételes bemutatása, azonban áttekintést kíván adni az ezeket tartalmazó jogszabályok és belső rendelkezések minél pontosabb feltüntetésével és a további kutatásokat is segítő bibliográfia összeállitásával. A továbbiakban az idegenekre vonatkozó szabályok kialakulását, az idegenrendészet határterületeit, a magyar idegenjog dualizmuskori értelmezését illetve ennek két világháború közötti változásait, valamint a külföldiek ellenőrzését a gyakorlatban megvalósító hatóságok és fegyveres testületek feladatait mutatom be. Ennek során a jogszabályi környezeten túl elsősorban az állami rendőrségek, ${ }^{\mathbf{8}}$ valamint a Magyar Királyi Csendőrség tevékenységét emelem ki, mivel e témában nem született még átfogó, a külföldiekkel kapcsolatos eljárásrendet részleteiben is tárgyaló tudományos igényü írás.

\section{Az idegenekre vonatkozó szabályozás kezdetei}

$\mathrm{Az}$ állam vagyonának, érdekeinek és népének védelme az ismeretlen idegenek okozta veszélyektől szinte egyidős az első ókori államalakulatok megjelenésével. Az alattvalók egy jól körülhatárolható szabályrendszer szerint éltek, szándékaikra és cselekedeteikre a mindenkori uralkodó hatást gyakorolhatott. Az idegen népek fiai, az állam területére érkező utazók és kereskedők azonban a fogadó ország kultúrkörétől ismeretlen szokások és értékrend szerint cselekedhettek, majd távozhattak és az uralkodói hatalom territóriumán kívülre kerülhettek. Az utazás ellenőrzésnek szüksége éppen ezért már az első írott jogot alkotó civilizációknál megjelent. Az ókori Egyiptomból ismerünk jelentéseket a birodalom határait átlépni szándékozó idegenek ellenőrzéséről, a beléptetés megtagadásáról, illetve „tiltott határátlépés” felfedéséröl. A határ őrzésével megbízott fegyveres alakulatok feladata az volt, hogy megállapítsák a birodalomba belépni szándékozó utazó tisztességes szándékait. ${ }^{9}$ Az egyiptomi uralkodók által az idegenek beutazására vonatkozó első szabályok tehát már az i.e. második évezredben megjelentek. Ez annak fényében válik igazán jelentős ténnyé, hogy a babiloni Nagy Király, Hammurapi törvényei - melyeket az írott jog kezdetének is tekintenek - az i.e. XVIII-XVII. században keletkezhettek, vagyis az idegenjogi szabályozási igény, ha kezdetleges formában is, de egyidős a jogalkotással.

A messze földről érkezett idegenek jogait és kötelességeit a Bibliában is fellelhetjük. Az Ószövetségben Ábrahám a hite miatt hagyta el ősei földjét, emiatt ,idegennek számitott az idegen földön" és elvesztette jogait. Az izraeliták számára az idegen (zar) eleve ellenség volt és a pogányok közé tartozott. Az átmenetileg Izrael földjén tartózkodónak nem voltak jogai, teljesen a nép vendégszeretetére volt utalva. A jövevény (ger vagy tosab) azonban bekerülhetett a közösségbe, ugyanis a legösibb héber törvénykönyv, a Szövetség Könyve kimondta, hogy Izrael fiai ne nyomják el a jövevényeket és felebaráti szeretettel fogadják őket, ha a közösség számára értékesek. Az idegen, vagyis az állam számára kártékony személy, és a jövevény, vagyis a közösség hasznos tagja között tettek különbséget, ami egyúttal azt jelentette, hogy nem minden külhonit láttak szívesen. A későbbi törvények már több jogot biztosítottak az idegeneknek, ugyanakkor különféle vallási és kultikus kötelezettségeket is elöírtak számukra. ${ }^{10}$ 
Európában a közel-keleti és görög forrásból is táplálkozó római jog a szabad emberek közösségén belül megkülönböztetett római polgárokat (cives Romani) és az összes többi néphez, állami közösséghez tartozókat (status civitatis). A római állam elsősorban saját polgárainak életviszonyait kívánta a köz- és magánjog által szabályozni. A nekik biztosított saját jog, a ius Quiritium (későbbi elnevezéssel: ius civile) által olyan lehetőségeket és kötelezettségeket írt elő, melyek a római közösség tagjait az összes környező idegen néptől megkülönböztették. A római polgárjogot elsődlegesen születési jogon lehetett megszerezni és alapfeltétel volt, hogy az apa a fogantatás idején római polgár legyen. Mesterséges módjai is voltak a polgárrá válásnak: a polgárjog egyéni vagy csoportos adományozása, valamint rabszolgáknak a ius civile szabályainak megfelelő, római polgár által történő felszabadítása révén. Római polgárnak lenni annyit jelentett, mint jogképességgel rendelkezni, vagyis a köz- és magánjog legfontosabb alanyaként olyan jogokkal rendelkezni, melyekböl más közösségek tagjai, vagyis az idegenek részben vagy teljesen ki voltak zárva. ${ }^{11}$

A római katolikus keresztény magyar államalapítást követően hazánkban is megjelentek az idegenekre vonatkozó szabályok. Már Szent István intelmei, Szent László és Könyves Kálmán dekrétumai is rendelkeztek a nem kívánatos idegenek eltávolításáról, valamint ,igaz úton" érkezésük megvizsgálásáról. ${ }^{12}$

Szent Istvánnak Imre herceghez intézett intelmei szerint a vendégek és jövevények befogadása hasznos, tehát „lakjanak itt szívesebben, mint másutt." Ez egyaránt vonatkozott a bevándorló népekkel szembeni türelemre és a Nyugat-Európából betelepülők idecsábítására. Könyves Kálmán dekrétumainak első könyve azonban már arról ír, hogy kezesség nélkül ne fogadják be a jövevényeket és idegen papokat. Minden idegen csak egy magyar honos kezességvállalása mellett volt befogadható. Az idegen papoknak püspökük ajánlólevelével kellett igazolniuk megfelelőségüket, különben az „országból kitakarodtak”, vagyis kiutasították őket. A rendelkezés a jövevény papokra vonatkozóan jelent csak meg, de feltehetően valamennyi idegennel kapcsolatban alkalmazhatták a kiutasítás korai formáját. ${ }^{13}$ Szent László dekrétumai második könyvében már a kereskedőkre és a vendég lakosokra is születtek rendelkezések és a jövevények letelepedése csak a helyi elöljáró engedélyével történhetett meg egy községben. Ez mind a külföldi, mind a belföldi idegenekre vonatkozott.

Általános érvényü idegenjogi normát ezt követően csak II. András alkotott az 1222. évi törvényével miszerint az ország tanácsának engedélye nélkül méltósághoz nem juthattak idegenek. $^{14}$ 1222-ben a király újabb törvénnyel tiltotta el az idegeneket ${ }^{15}$ a birtokadományozás általi vagyonszerzéstől is, azonban a nemzet fiaihoz hasonló szabadságot adott nekik az egyéb tulajdonszerzésben.

Külön szabályok vonatkoztak a Kárpát-medencébe a magyarokkal együtt érkező vagy később csatlakozó népek jogállására, akiknek letelepedését, szokásait, életét kiváltságlevelekben rögzítették. Ilyenek voltak a besenyők, böszörmények és izmaeliták később a kunok és jászok, majd a német hospesek és szászok. ${ }^{16}$ Ők ugyan nem voltak ,idegenek”, de speciális jogi szabályozás mellett éltek a magyar területeken. Az erdélyi szászok befogadásáról és kiváltságaik megerősítéséröl II. András 1224-ben adott ki oklevelet (Diploma Andreanum), 1230-ban pedig a német hospesek kaptak hasonló kiváltságlevelet. Ezekben a saját bíráskodásra, szabad papválasztásra és egyfajta területi autonómiára kaptak felhatalmazást a királytól. A kunok 1239-ben telepedtek le az országban és 1279-ben IV. Kun László uralkodása alatt az országgyülés megalkotta az úgynevezett kun törvényeket (Articuli Cummanorum). Károly Róbert uralkodása alatt hasonló kereteket adtak a jászok letelepedésének is. ${ }^{17}$

Fontos azonban, hogy a magyar közösség, a politikai nemzet egyes csoportjaira vonatkozó korlátozásokat nem tekintették idegenjogi kérdésnek. Így a zsidókra és izmaelitákra vonatkozó korlátozó szabályok (pl. nem tarthattak keresztény cselédet) nem tekinthetők idegenrendészeti jellegünek, mivel a nem keresztény vallásúakat is a populas Hungarorum részeként kezelték. A populas Hungarorum fogalma alatt a beszélt nyelvtől függetlenül azt a politikai nemzetet értették, amely révén megkülönböztethetök voltak az országban polgárai az ott született külföldiektől, vagyis a korlátozó rendelkezések ellenére a magyarországi nem keresztény hitközösségeket nem vonták az idegen fogalomköre alá. ${ }^{18}$

Ahogy az európai államok területe mind jobban körülhatárolhatóvá vált és a királyi 
hatalom földrajzi terjedelmét a birtokhatárok helyett az államhatárok határozták meg, az „állam-terület” és az ,állampolgárság” egyre pontosabb megfogalmazása is szükségessé vált. Ezzel azonban szükségszerüen együtt járt a fentieken kívül eső területek és egyének meghatározása is, vagyis a „saját” terület és polgár mellett az „idegen” fogalma is egyre inkább körvonalazódott.

A XV. század végétől úgy tekintettek az idegenekre, mint korlátozott jogképességgel bírókra, mivel nemesi jószágot és tulajdont nem szerezhettek. Mint látható a XVIII-XIX. századig a magyar idegenjogi jogszabályok többsége föleg a külföldiek jogainak korlátozását, a tisztségek magyar nemesekkel való betöltését, a birtokszerzés korlátozását, valamint az idegen kézben levő birtokok magyarok általi megváltását tartalmazták. ${ }^{19}$ A számos, külföldiekkel kapcsolatos rendelkezéseket is tartalmazó törvény ${ }^{20}$ közül WERBÖCZY István Hármaskönyve és az 1653. évi Approbáták rendelkezései emelkedtek ki.

Az 1504. és 1514. között összeállított Hármaskönyv ${ }^{21}$ összefoglalta az idegenekkel kapcsolatos normákat és egy-három hónap türelmi időt biztosított a jövevényeknek, hogy az ország törvényeit megismerhessék. Az Approbáták ${ }^{22}$ Harmadik Könyve volt az első magyar jogi szabályozás, amely rendszerbe foglalta az idegenekkel és jövevényekkel kapcsolatos rendelkezéseket. Ez egyrészt a nemes emberek honosításáról, másrészt a vándorló idegenek és jövevények kezeléséről rendelkezik. Utóbbiakról kimondja, hogy azokat a földesúr tegye jobbágyává és senki ne türje meg kóborlásukat. Ez elsősorban az akkori rendi társadalom közbiztonságának volt egyetemes követelménye. ${ }^{23}$

Újszerü szabályozást vezetett be a külföldi kereskedőkről szóló 1715. évi törvényi szabályozás, ${ }^{24}$ melyben a későbbi idegenrendészeti előállítás és kiutasítás elődje is megjelent. A rendészeti szabályok megfogalmazása még itt is a külföldiek foglalkozásától függött, azonban a szabályok megsértőivel szemben nem büntetőjogi, hanem közigazgatási eszközökkel jártak el és a helyi elöljáró joghatósága alá tartoztak. Az idegenekkel kapcsolatos rendelkezések érvényre juttatása ettől kezdve egyre inkább a közigazgatás kompetenciája lett.

A magyar idegenjogi szabályozás fejlődésére nagy hatást gyakorolt a Habsburg Birodalommal fennálló kapcsolat. Az Osztrák-Magyar Monarchia létrejöttével meghatározásra került a közös ügyek köre, melyeken kívül a társországok saját hatáskörben intézkedtek. A külföldiek beutazásának és magyarországi tartózkodásának szabályozását és ellenőrzését, valamint a határörizeti feladatokat tekintve a magyar kormány önállóságot élvezett. ${ }^{25}$

A határok pontos kijelölésére, 1888-ban romániai, 1889-ben horvátországi, 1902-ben galíciai, majd 1910-ben ausztriai határszakaszokon került sor. A földrajzi pontosítást rendszerint a szomszéd országok polgáraira vonatkozó szabályok pontosítása és annak megfogalmazása követte, hogy e szabályok betartásának ellenőrzése miként történjen. A XIX-XX. század fordulójára mind szabályozásában, mind szervezeti kereteit tekintve létrejöhetett az a rendszer, amely biztosította a Magyarországra érkező külföldiek ellenőrzését és a velük kapcsolatos adminisztratív teendők elvégzését.

Az I. világháború közeledtével egyre részletesebb és szigorúbb idegenrendészeti szabályok láttak napvilágot. A háborút követő zürzavar és a trianoni békediktátum teljesen új helyzetet teremtettek az országban és új kihívások elé állították az állampolgársági, menekültügyi és idegenrendészeti feladatokkal megbízott állami szervezeteket. A két világháború között a magyar idegenrendészeti szabályrendszer a korszak sajátosságainak megfelelően, de még stabilan a dualista alapokon nyugodva fejlödött. A világháború előtti időszak liberális szellemủ gondolkodását és szabados határátlépési szabályait szigorúan szabályozott és ellenörzött rendszer váltotta fel, amely egészen a II. világháború kitöréséig finomodott és fejlödött.

\section{A külföldiek ellenőrzésének elmélete és gyakorlata}

Mielőtt az idegenrendészet témakörének részletes tárgyalására sor kerülne, szükséges azoknak a szabályoknak az áttekintése, melyek csak érintőlegesen kapcsolódtak a külföldiek rendészetéhez. Az idegenrendészeti szabályrendszer határterületeinek a vizsgált korszakban a belföldi idegenellenörzés, a kivándorlás, és az emberkereskedelem elleni fellépés tekinthetö, valamint nem kerülhető meg a magyar állampolgárság témaköre sem.

Az idegen kifejezés a kiegyezés korának jogalkotásában és rendészeti szakmai termi- 
nológiájában egyaránt jelentette a nem magyar állampolgárokat, valamint azokat a magyar honosokat, akik illetőségi helyükön kívül tartózkodtak. A magyar közigazgatást alapjaiban meghatározó községi illetőség és az idegenrendészet kapcsolatrendszere a későbbiekben kerül kifejtésre, összességében elmondható azonban, hogy a XIX. század végéig a belföldi és külföldi idegenek ellenőrzése ugyanazon jogi alapokon nyugodott. Ez az alap az illetőségi községen kívüli tartózkodás volt. A belföldi idegenek ellenőrzése föként a házaló árusokra és vándoriparosokra vonatkozó rendelkezések betartatásából, valamint a csavargók és adománygyüjtők felügyeletéből állt. E jogszabályoknak is volt azonban külföldiekre vonatkozó tartalma. magyar büntető-törvénykönyvek végrehajtása tárgyában kiadott 1880 . évi belügyminisztériumi körrendelet szerint ${ }^{26}$ az igazolvány nélküli átutazó, vándoripart üző külföldiek esetében előzetes letartóztatásnak volt helye, házaló árusítást pedig csak magyar állampolgároknak engedélyeztek. ${ }^{27}$

A korszak másik sajátossága volt, hogy az országba bejutni szándékozó külföldiek ellenőrzése mellett a fegyveres testületek határszéli szolgálatai kiemelten kezelték az országból kijutni törekvő magyar állampolgárok ellenőrzését is. Mivel a kivándorlók a határ átlépéséig belföldi idegenként utaztak, felügyeletüket a szakirodalom sokszor az idegenrendészettel együtt kezelte. A kivándorlás ügyét a magyar országgyülés 1903-ban, majd 1909-ben szabályozta ${ }^{28}$ Eszerint kivándorlónak volt tekinthető, aki „,tartós kereset céljából külföldre távo$z i k$ ". A valamely európai államba egy évnél rövidebb időre, meghatározott munka elvégzésére kiutazó személy kivételt képezett e generális szabály alól. A kivándorláshoz kivándorlási engedélyre volt szükség. Az engedélyért folyamodók esetében vizsgálták, hogy betöltötték-e nagykorúságukat - ami a 24. életév volt $-{ }^{29}$ biztosítva van-e megélhetésük, munkahelyük a fogadó államban, valamint nem hagynak-e hátra gondozásra szoruló családtagot. A nőknél külön vizsgálták, hogy nem merültek-e fel leánykereskedelemre utaló jelek. A hadköteles korú férfiak kivándorlási engedélyt csak a belügy- és a honvédelmi miniszter által óvadék mellett adott írásos engedély birtokban szerezhettek. A kivándorlás komoly korlátja volt még a „,büntetendö cselekmény” miatt elrendelt szabadságvesztés kiszabása, vagy folyamatban levő büntetőeljárás. A kivándorlás lehetősége ekkor csak az elévülési idő letelte után nyílt meg. Büntetendő cselekmény alatt az elzárással büntethető kihágásokat is érteni kellett, vagyis a korlátozás nemcsak a büntettek és vétségek elkövetőire vonatkozott.

Bár csupán becsülhető a kivándorlók száma minden bizonnyal állítható, hogy a vizsgált időszakban legalább 3-4 millió föt tett ki, amely az akkor mintegy 20 milliós ország lakosságának tetemes részét jelentette. A hivatalos kimutatásokat csak a XIX. sz. végétől kezdték vezetni. A magyar kormány nem kívánta megakadályozni a kivándorlást, de korlátozó rendelkezéseket vezetett be és ellenőrizhető keretek közé kívánta szorítani oly módon, hogy az ebből származó jelentős haszon magyar vállalatokat gyarapítsa. ${ }^{30} \mathrm{~A}$ rendőrség és a csendőrség határszéli alakulatai és más ellenőrző szervek elsősorban a kivándorlási engedélyt nyert személyek útleveleinek, valamint a kivándorlók szállítását végző személyek belügyminiszter által kiadott tevékenységi engedélyének ellenőrzésében vettek részt. A kivándorlásra toborzás, felhívás, valamint az engedély nélküli szállítás büncselekmény volt. ${ }^{31} \mathrm{~A}$ vétség bünsegédi magatartásai, úgymint az elkövetőkkel fenntartott üzleti összeköttetés vagy tevékenységük támogatása hivatalból üldözendő kihágást valósított meg. A Kúria értelmezése szerint a jogsértés már akkor megvalósult, ha valaki egy kivándorlásra nem jogosult személynek megmutatta a legközelebbi kivándorlási irodát. ${ }^{32}$ Ugyanezt a kihágást követte el az a magyar állam-polgár is, aki útlevél nélkül vagy a törvény tilalma ellenére kivándorlás céljából útra kelt.

A szabályozás tehát meglehetősen szigorúnak mondható, különösen a dualizmuskori jogrendszerben. Figyelembe kell azonban venni, hogy a kiegyezést követően évtizedek teltek el, mire a törvényhozás megalkotta a szigorú szabályozást. A szabályok betartatása pedig lényegében lehetetlen volt, mert az Osztrák-Magyar Monarchián belül a Magyar Királyság határait bárki szabadon átléphette és Ausztria, valamint a német tartományok határain sem tartóztatták fel az észak-német kikötővárosokba tartó kivándorló tömegeket. Mivel a határokon nem volt regisztráció, ezért a kivándorlásra utaló legfontosabb iratok a német hajóstársaságok utaslistái. Ezeket azonban — többek között a nemzetiséghez tartozás tekintetében - nem lehet pontosnak tekinteni, mivel bemondás alapján készültek. 
A korabeli magyar szabályozás azonban a XIX. század végén igyekezett szervezett keretek közé szorítani a kivándorlást, másrészt védelmet nyújtani a jogszerúen utazó polgároknak. Aki nem felelt meg a kivándorlási törvényben megfogalmazott követelményeknek, azt a csendőr vagy a rendőr igazoltatta, feltartóztatta és visszatoloncolta. A felfedett kihágások miatt a csendőr a föszolgabírónál tette meg feljelentését, az állami rendőrség müködési területén a rendőrség járt el. Ehhez azonban bizonyítani kellett azt is, hogy az illető szándékában állt a kivándorlás.

A más országokból kivándorlási szándékkal Magyarországon keresztül utazó külföldiek ellenőrzésekor hasonló rendelkezésekre kellett figyelemmel lenni, melyek közül az emberkereskedelem (vagy akkori szóhasználat szerint a leánykereskedelem) elleni fellépés kiemelkedő feladat volt. Az erről való gondolkodás meghaladta korát, bár a cselekmény üldözése nagy múltra tekint vissza.

Az emberkereskedelem elleni első rendelkezést már Szent László dekrétumai második könyvében megjelentek, miszerint „magyar nemzetbeli szolgát vagy akárkit, aki Magyarországon született, ha idegen nemzet is, avagy szolgálóleányt, kivéve a más tartományokból hozott más nyelvet beszélöket, senki el ne adjon." 33

Az emberkereskedelem újkori szabályozását törvénnyel Magyarországon 1908-ban rendezték, amely a kerítés büncselekménnyel egy tekintet alatt kezelte a tisztességes nőknek erkölcstelen szándékból való külföldre szállítását. ${ }^{34} \mathrm{~A}$ rendelkezés vonatkozásában tisztességes nő az volt, akinek erkölcsi értéke csökkenést szenvedett a kerítés által. ${ }^{35}$ A szabályozás továbbfejlesztését a nőkkel és a gyermekekkel űzött kereskedés elnyomása végett Genfben létrejött nemzetközi egyezmény becikkelyezése tárgyában kiadott 1925. évi törvény képviselte, amely a büntetőjogi védelmet bizonyos feltételekkel a férfiakra is kiterjesztette. ${ }^{36} \mathrm{Az}$ ellenőrző hatóságok és közegek minden esetben vizsgálták, hogy az országból kiutazni szándékozó magyar állampolgárok és átutazó külföldiek nem estek-e emberkereskedő áldozatává illetve nem állnak-e kényszer hatása alatt. A kérdéskör ma is részét képezi a határellenőrzés folyamatának és ezáltal az idegenrendészeti ellenőrzések rendszerének is.

Az idegenekre vonatkozó szabályok megállapításának előfeltétele az állam saját polgárai körének meghatározása és az állampolgársággal kapcsolatos szabályok lefektetése. Az állampolgárság jogi szabályozása meghatározó volt az idegenrendészeti szabályrendszer szempontjából, hiszen az volt külföldinek tekintendő, aki nem volt magyar állampolgár. Magyarországon az első ünnepélyes honfiúsításra bizonyíthatóan 1542-ben került sor, vagyis már évszázadokkal ezelőtt felmerült az igény arra, hogy valaki a jog kereti között idegenből hivatalosan magyar állampolgárrá váljon. ${ }^{37}$

A magyar állampolgárság témáját a Magyar Királyságban teljes körúen önálló jogszabályban először 1879-ben szabályozta az országgyülés. ${ }^{38} \mathrm{Az}$ ezt megelőző időkben is voltak a polgárok jogairól és az idegenek jogállásáról szóló rendelkezések, de kifejezetten állampolgársági jogszabály nem létezett. Az 1848-1849-es forradalmat és szabadságharcot megelőző időkben erre nem is volt szükség, hiszen a közéletben csak a nemesek vettek részt, így csak ők számítottak honpolgárnak, míg a nem nemesek és idegenek az ehhez kapcsolódó jogok többségéből ki voltak zárva. A szabadságharc előtt ünnepélyes honfiúsítással, vagyis királyi oklevél megszerzésével, hüségeskü letételével és a szükséges díj megfizetésével válhatott valaki magyar honpolgárrá, vagy úgynevezett hallgatólagos honosságszerzés útján. Az utóbbi esetben a külföldi valamely város polgárainak sorába felvételt nyert, erről honlevelet kapott, ott háborítatlanul tartózkodott és adózott, majd a meghatározott idő elteltével hallgatólagosan magyar honpolgárságot nyert. ${ }^{39}$ Az 1814. évi 10661 számú udvari rendelet értelmében egészen az 1850-es évekig hallgatólagosan magyar honosságot szerzett az, aki 10 éven keresztül a fenti feltételekkel Magyarországon tartózkodott. Az így szerzett állampolgárság azonban a nagykorú gyermekekre nem terjedt ki. A honosság elvesztése csak házasság útján volt lehetséges. A családok elbírálásánál a férjnek engedélyezett honosítás általában vonatkozott a feleségre és az atyai hatalom alatt álló gyermekekre, míg a házasságkötés automatikus állampolgárságot keletkeztető ok volt. A családegyesítésre történő hivatkozás ekkor még ismeretlen volt a honosítási vagy letelepedési eljárásban. ${ }^{40}$

Az 1879. évi honossági törvény és végrehajtási rendelete ${ }^{41}$ megtartotta és elismerte a régi szerzési módokat (királyi oklevél, hallgatólagos szerzés, házasságkötés), de hatálybalépését követően csak az abban foglalt feltételekkel volt megszerezhető a magyar állampolgárság. A 
jogszabály időtállónak bizonyult, azonban a közjogi viszonyokkal történő harmonizálása érdekében a későbbiek során több jogszabály is módosította. ${ }^{\mathbf{4 2}}$

Az állampolgársági és az idegenrendészeti szabályrendszer közti fontos kapcsolódási pont volt a községi illetőség kérdése. A korabeli közigazgatás egyik sarokköve szerint minden magyar honpolgár valamely község kötelékébe tartozott, amely róla igazgatási, szociális és szükség szerint „szegényügyi” szempontból gondoskodott. A leginkább a mai állandó lakóhelyhez hasonlítható illetőségi község lényegében egy településnek felelt meg, mivel valamennyi helység - emberek meghatározott csoportjára nézve - egyúttal illetőségi község is volt. A jogintézmény elsősorban a közellátásban részesülő szegények ügyeinek rendezését célozta, mivel az egyes községek feladatává tette a gondozást és segélyezést, de rendészeti szempontból is kiemelkedő jelentőséggel bírt. A községi illetőség megléte olyannyira meghatározó volt, hogy minden magyar állampolgárságért folyamodó külföldinek először valamely község kötelékébe való felvételét kellett kérnie.

A községi illetőség témáját az országgyülés először 1871 -ben szabályozta. ${ }^{43}$ Mivel ez szinte kizárólag a szegények szociális ellátásának szemszögéből vizsgálta az illetőség kérdését, csakhamar kiegészítésére volt szükség, melyet a téma 1876. évi szabályozása valósított meg. ${ }^{44} \mathrm{Az} 1879$. évi állampolgársági törvény hatályba lépésével azonban új megközelítésre volt szükség. ${ }^{45}$ A jogszabályi összhang megteremtésére tett erőfeszítések eredményeként született meg a községekröl szóló 1886 . évi törvény. ${ }^{46}$ A jogszabály már kifejezetten tiltotta a külföldieknek a községi kötelékbe való végleges felvételét, mivel az csak a honosítást követően lehetséges. Ennek ellenére a külföldiek letelepedési engedélyt nyerhettek és a községi kötelékbe való felvételt kilátásba helyezhették részükre. ${ }^{47}$

Az állampolgárság és a külföldiek rendészete közötti sajátos kapcsolatról árulkodik a tömegesen visszatelepülők honosításáról szóló 1886 . évi törvény ${ }^{48}$ is, amely a magyar nemzetiségüek országon belüli arányának növelésére tett intézkedések keretében született, és hatására bukovinai székelyek és csángók betelepítésére került sor. A jogszabály olyan magyar nemzetiségúek kedvezményes honosítását írta elő, akiknek a továbbiakban nem volt kötelező életvitelszerüen Magyarországon tartózkodni. ${ }^{49}$ A törvény olyan jogi helyzetet teremtett, melyben a kedvezményesen honosítottak bár már nem voltak külföldiek, bárhol az országban — illetőségi község hiányában — idegennek számítottak.

$\mathrm{Az}$ egységes értelmezést nyert magyar állampolgársági szabályozás időtállónak bizonyult és mind a dualizmus időszakában, mind a két világháború között ez képezte alapját a saját állampolgárok és az idegenek közötti különbségtételnek. A témában a tárgyalt időszak utolsó jelentős jogszabályának a magyar állampolgárság megszerzéséről és elvesztéséről szóló 1939. évi törvény tekinthető, ${ }^{50}$ amely módosította és kiegészítette az 1879 . évi állampolgársági törvényt. ${ }^{51}$

\section{Az idegenrendészet értelmezése a dualizmus korában}

A dualizmus korának értelmezése szerint az idegenrendészet egyrészt a különböző hatóságok és fegyveres testületek határszéli szolgálati teendőinek részét képezte a határon már átlépett külföldiek ellenőrzése vonatkozásában, másrészt a közbiztonsági szolgálat fontos része volt, hiszen az „idegen” fogalma alatt nemcsak a külföldieket értették, de azokat a magyar állampolgárokat is, akik nem illetőségi helyükön tartózkodtak. A külföldi és belföldi idegenek ellenőrzésének éppen ezért azonos módszertana volt.

Az idegenrendészet határszéli szolgálattal érintkező területei olyan komplex rendszerbe illeszkedtek, ami több állami szervezet együttműködésével biztosította Magyarország érdekeinek érvényesülését. A határok és azokon átlépő forgalom ellenőrzése nem tartozott az Osztrák-Magyar Monarchia közös ügyei közé, annak megvalósítása az adott társállam polgári közigazgatásának kompetenciája volt. ${ }^{52}$ A kiegyezéskor a Magyar Királyság külállamokkal szomszédos határait a Magyar Királyi Pénzügyőrség határmenti szakaszai őrizték. A határátkelőhelyeken az utasforgalom ellenőrzését a legközelebbi város rendőrségének kikülönített csoportjai végezték, az áruforgalom felügyeletét pedig a területileg illetékes vámhivatalok „bemondó örsei” valósították meg. A határrenddel kapcsolatos teendők a határmenti járásokban e célra létrehozott szolgabírói kirendeltségekre hárultak. Határőrizet tehát csak a katonai határőrvidékek müködési területén kívül eső vámhatárokon valósult meg, ami kezdetben 
megoszlott a központi államhatalom (pénzügyörség és vámhivatalok), valamint az önkormányzatok között. Elmondható tehát, hogy a Magyar Királyi Csendőrség, majd a Magyar Királyi Határrendőrség határőrizetbe való bekapcsolódásáig a vezető szerep a pénzügyi tárcára hárult. ${ }^{53} \mathrm{Az}$ állategészségügyi feladatokat ezen kívül vesztegintézetek látták el, határőrizeti feladatai pedig közvetve a földmüvelési, ipari és kereskedelmi miniszter alárendeltségébe tartozó belépőállomásoknak és erdészeti közegeknek, valamint a közmunka- és közlekedésügyi miniszter irányításával működő révhivataloknak is voltak. ${ }^{54}$

A fenti szerteágazó és egységes központi irányítást nélkülöző határörizeti rendszert a Magyar Királyi Csendőrség megalakulása, majd a testületen belül a határszéli csendőrség, vagyis a határőrizeti szolgálati ág ${ }^{55}$ létrehozása helyezte új alapokra. A csendőri szervezet bekapcsolása a határőrizeti feladatokba az egyre növekvő közbiztonsági kockázatok eredménye volt. A hegyi erdőterületek közelében a századfordulót követően már jelentős időszakos települések és táborok jöttek létre. 1905-ben a határszéli telepeken hozzávetőlegesen 18000 , 1908-ban már 20-22 000 fakitermelő munkás dolgozott, akik között számos körözött bünöző talált menedéket. A táborokban kialakuló nemzetiségi összetüzések és rendzavarások komoly kihívást jelentettek. ${ }^{56}$ Az első lépést az 1891-ben kibocsátott határőrizeti utasítás jelentette, amely a Beszterce-Naszód vármegyében található hármas határponttól Orsováig terjedő határvonal védelmét a határcsendőrségre bízta feladataik részletes megállapítása mellett. Az utasítás a továbbiakban eltiltotta a pénzügyőrséget a határoorizeti feladatoktól és hatáskörük csak a jövedéki szabályok ellenőrzésére terjedt ki. ${ }^{57}$

A határörizet szervezeti rendszere azonban még mindig túl bonyolult volt a hatékony fellépéshez, így egy specializált hatóságra volt szükség a feladatok koordinálására. A határrendőrség felállításáról szóló törvénycikk 1903-ban látott napvilágot, de gyakorlati megvalósítására csak 1906. I. 15-től került sor. 12 új határszéli rendőrkapitányság felállításával egyidejüleg az érintett területeken megszüntették a „rendes rendőri hatóságok” határszéli teendőit. Az új szervezet feladata nem a szükebb értelemben vett határőrizet megvalósítása melyhez nem is rendelkezett elegendő személyi állománnyal — hanem az azzal kapcsolatos figyelő és nyomozó szolgálat ellátása, valamint az egységes irányítás megszervezése volt. A határrendőrség kapitányságai és az elsőfokú rendőrhatóságok (főszolgabíró, városi rendőrkapitány) egymással mellérendeltségi viszonyban álltak és kötelező együttmüködéssel támogatták egymás tevékenységét. A csendőrség a továbbiakban határmenti járőrszolgálatok ellátásával, esetleges karhatalmi erő kiállításával, megfigyelésekkel, valamint a nyomozások segítésével kapcsolódott a rendszerhez. A határrendőrség felállításával a járási szolgabírói kirendeltségek megszüntek, feladataikat a határrendőr kapitányságok és kirendeltségek vették át. ${ }^{58}$

A határrendőrség felállításáról szóló törvényt az országgyülés a kivándorlásról, a külföldieknek Magyar Szent Korona országainak területén való lakhatásáról, valamint az útlevélügyről szóló törvény ${ }^{59}$ társaságában tárgyalta, ami az utazással és idegenrendészettel kapcsolatos szabályozási igény felértékelődését jelentette. ${ }^{60}$

1912-ben külföldi tapasztalatok nyomán a határőrizeti rendszert átszervezték, a határrendőri őrségek állományát a kirendeltségek és kapitányságok szervezetébe olvasztották, így a járőrszolgálati (vagy akkori szóhasználttal külszolgálati) feladatok teljes mértékben a csendörséghez kerültek. Emellett a helyi csendőri erök átvették az útlevél-ellenőrzést több határkapunál és a határszéli úti igazolványok kiállítására is hatáskört kaptak. Azokon a határállomásokon, ahol az átszervezés után is a határrendőrség végezte az útlevélvizsgálatot, a csendőrség ügyeleti szolgálatot volt köteles adni minden érkező és induló vonatnál és hajónál. ${ }^{61}$

Összességében elmondható, hogy a csendőrségnek a határőrizetbe való bevonásával az egylépcsős modell kétlépcsőssé vált, melyet egyrészt a pénzügyőri szakaszok, másrészt a határszéli csendőrőrsök alkottak. Mindkét lépcső saját feladatkörén belül többvonalas rendszert képezett, vagyis az államhatártól különböző mélységekben, több egymást követő vonalban müködtették járőrszolgálati rendszerüket. Ezzel nyílt meg először annak a lehetősége, hogy müködőképes ellenőrzési rendszert - mai terminológia szerint migrációs szürőhálót - hozzanak létre, melyet kis létszámú erővel is sikeresen lehetett müködtetni. A pénzügyőrség, határszéli csendőrség és határrendőrség személyi állományának kétharmada a magyar-román, egyharmada magyar-szerb határon teljesített szolgálatot, ami egyben a határszakaszok koc- 
kázati besorolását is jelezte. ${ }^{62}$

A magyar határőrizeti modell lényegét tekintve a nyugat-európai típushoz sorolható, mivel békeidőben rendvédelmi testületek valósították meg a határok őrizetét, szemben a keleteurópaival, ahol békében is katonai erők végezték ezt a tevékenységet. ${ }^{63}$ A magyar modell sajátossága volt, hogy a nemzeti rendvédelmi testületek határmenti alakulatai láttak el olyan határőrizeti részfeladatokat, melyek összhangban álltak alaptevékenységükkel. Szükséges volt azonban a Magyar Királyi Határrendőrség vezető szerepe, amely összehangolta és egységesítette e feladatokat. ${ }^{64} \mathrm{~A}$ csendőrség kiegészítette valamennyi szervezet feladatrendszerét és gyakorlati végrehajtó erőként a hatóságok munkáját támogatta. Az útlevél nélkül elfogott, csempészéssel nem gyanúsítható személyeket például a határrendőr kapitányságra állította elő, a büncselekmény miatt körözött külföldieket pedig a járásbíróságra. A határszéli csendőr őrsök kötelessége volt az is, hogy 24 óránként a vám és pénzügyőri hivataloktól az útlevél nélkül elfogott csempészeket átvegye és a határrendőr kapitányságra kísérje. ${ }^{65}$ A csendőr tehát csak elfogta a jogsértést elkövetőket, a szükséges eljárásokat az adott szakterület felelős hatósága folytatta le.

A számos átszervezésen átesett rendszer képes volt kiszürni a legális utasforgalomból azokat a személyeket, akik tevékenységükkel vagy a birtokukban tartott tárgyak által veszélyt jelentettek a magyar államra. A szükebb értelemben vett, határszéli szolgálathoz kapcsolódó idegenrendészet azonban csak erre korlátozódott, a jogsértést elkövető külföldiek állampolgárságának és személyazonosságának megállapítását elsősorban közbiztonsági érdeknek tartották.

Az ország mélységében tartózkodó külföldiek ellenőrzése hasonló alapokon nyugodott, mint a korabeli határörizeti rendszer. A kiegyezést követő első törvény, amely a külföldiek itt tartózkodását is érintette az 1871-ben jött létre ${ }^{66}$ Eszerint a két éve folyamatosan itt tartózkodó és adót fizető külföldiek a községi kötelékbe felvehetők, amennyiben e szándékukat bejelentik. ${ }^{67}$ Ezt a községekről szóló 1876 . évi törvény bővítette ki. ${ }^{68}$ A külföldiek letelepedését első ízben, de még nem teljes körüen a községekröl szóló 1886 . évi törvény szabályozta. ${ }^{69}$ Eszerint a külföldi állandó lakhatási (letelepedési) szándékát három hónapot meghaladó tartózkodás esetén volt köteles bejelenteni az illetékes elöljáróságnál. Ennek elmulasztása kihágást valósított meg.

A korabeli közigazgatási felfogás lényege az volt, hogy minden kártékony idegen személyt az illetőségi helyére kellett visszatoloncolni. Aki tehát koldulásból vagy büncselekmények elkövetéséből élt, azt visszatoloncolták származási helyére, ahol rehabilitálhatták. A külföldieket származási országukba juttatták vissza, vagyis közbiztonsági intézkedésként kiutasították. A koldulás vagy csavargás kihágások miatt elítélt külföldieket a büntetés kiállása után az országból kiutasíthatták, mellyel rend szerint élt is a rendőri büntetőbíróság. ${ }^{70} \mathrm{~A}$ közigazgatási hatóságok kitiltási és kiutasítási jogának forrása tehát az úgynevezett Toloncszabályzat volt, amely 1885-ben rendelet formájában jött létre ${ }^{71}$ amely még az 1930-as években is hatályban maradt.

A tolonchatározat elleni fellebbezésnek halasztó hatálya nem volt és a Kúria 10086/1892. sz. határozata szerint a kitiltott vagy kiutasított személy engedély nélküli viszszatérése akkor is kihágást valósít meg, ha kitiltás helytelen jogi alapon vagy hibás eljárás keretében történt. A bíróság által jogerősen kimondott kitiltást vagy kiutasítást sem felfüggeszteni, sem visszavonni nem lehetett, míg a közigazgatási hatóság hasonló döntése felfüggeszthető volt. ${ }^{72}$

1898-ban elügyi elvi határozat mondta ki, hogy magyar állampolgár csak abban az esetben volt eltávolítható a nem illetőségi községéből, ha ott tartózkodása közbiztonsági vagy közerkölcsi okokból nem volt megengedhető. ${ }^{73} \mathrm{Ez}$ a rendelkezés természetesen a külföldiek kiutasítására is igaz volt, esetükben azonban számos más ok is vezethetett a hatósági intézkedéshez. A következő évtizedekben az idegenrendészeti szabályozás fejlődésével egyre szélesebb körben volt lehetőség a „kártékony” idegenek eltávolítására. A közveszélyes munkakerülésről szóló 1913. évi törvény szerint például azt, aki csavargással, a rendes polgári életmód és foglalkozás szándékos kerülésével, valamint kimutathatóan büncselekmények elkövetésével tartja fenn magát, kihágás miatt kellett felelősségre vonni. Ha a kihágás elkövetője külföldi volt, öt az országból ki lehetett utasítani és a visszatéréstöl meghatá- 
rozott időre vagy akár élethosszig eltiltani. ${ }^{74}$ A kiutasítást a külföldieknek a Magyar Szent Korona területén való lakhatásáról szóló 1903. évi törvény alapján is ki lehetett mondani a hasonló életmódú személyekkel szemben. ${ }^{75}$

Természetesen a veszélyt jelentő külföldiek eltávolításának legkézenfekvőbb módját a magyar bíróságok is alkalmazták. A magyar büntetőtörvénykönyv szerint a büntettet elkövető külföldiek kiutasításuk mellett határozott időre vagy örökre eltilthatók voltak a visszatéréstől. ${ }^{76}$

Érdekes, hogy míg a kitiltás és kiutasítás végrehajtását meglehetős szigorral kezelte a magyar közigazgatás, addig az ezt elrendelő hatósági rendelkezések megszegését kevésbé. Aki a magyar állam területéröl vagy annak egy részéről kitiltásra került, és oda engedély nélkül visszatért, csupán elzárással büntethető kihágást követett el. Az ilyen ügyekben a főszolgabíró és az állami rendőrség, vagyis csak rendőri büntetőbíróság bíráskodott. ${ }^{77}$

Ahogy a „rosszhirư"' idegenek kitoloncolása idővel idegenrendészeti kiutasítássá és hatósági toloncolássá fejlődött, úgy vált egyre kidolgozottabbá a külföldiek ellenőrzésének egyik sarokköve, a tartózkodás bejelentése is. A bejelentési kötelezettségről szóló 1879. évi törvény értelmében az idegenek érkezésének és távozásának bejelentési kötelezettsége a föváros területén általános volt, melyet a bejelentőhivatalok útján kellett teljesíteni. A lakás- vagy szálláshely tulajdonosok tehát bejelenteni tartoztak minden náluk megszálló személyt, akinek Budapesten más bejelentett lakóhelye nem volt. Ennek elmulasztása a rendőrség hatáskörébe tartozó hivatalból üldözendő kihágást valósított meg. A magánháztartás feje a törvény szerint bejelenteni volt köteles a háztartásához tartozó személyeket is. ${ }^{78}$

A magyar és külföldi gyermekek születésének bejelentését szintén a bejelentési kötelezettségről szóló 1879. évi törvény szabályozta, mely szerint egy héten belül az illetékes anyakönyvvezetőnél bejelentést kellett tenni. Az anyakönyvvezető hetente tájékoztatta a bejelentőhivatalt a nála tett bejelentésekröl. A születés és halálozás bejelentésével kapcsolatos kihágások elbírálására a járásbíróságok voltak illetékesek. ${ }^{79}$

Ott, ahol nem müködött bejelentőhivatal, a bejelentési kötelezettség részleges volt, vagyis csak a végleges elköltözést és a lakhely 3 hónapon túli megváltoztatását kellett a hatóság tudomására hozni. A fenti rendelkezések egyaránt vonatkoztak a belföldi és külföldi idegenekre. A bejelentés és nyilvántartás kérdéskörét számos alacsonyabb szintü jogforrás is tárgyalta, melyek közül külön említésre érdemes a külföldieknek a községekben való lakhatása tárgyában kiadott 1888 . évi BM rendelet, ${ }^{80}$ a külföldiek nyilvántartása tárgyában hozott szabályrendeletek életbeléptetése iránt kibocsátott 1895 évi BM rendelet, ${ }^{81}$ valamint a külföldieknek a községekben lakhatása ügyében kibocsátott rendelet pontos végrehajtására született 1898. évi BM rendelet. ${ }^{82}$

A külföldiek bejelentési kötelezettségét és a velük kapcsolatos más szabályokat a külföldieknek a Magyar Szent Korona országai területén való lakhatásáról szóló 1903. évi törvény helyezte új alapokra. Első igazi idegenjogi törvényünk elöször foglalta egységes szerkezetbe sajátos joganyagként a külföldiekre vonatkozó hazai szabályozás legfontosabb tételeit és lefektette az idegenrendészet máig ható legfontosabb elveit. A törvény valódi jelentősége abban áll, hogy a kiadását követő 90 évben nem volt példa hasonlóan magas jogalkotói szinten megjelenő idegenrendészeti normára. ${ }^{83}$ Mivel a II. világháborút követően az idegenjogot rendeleti szinten szabályozták és csak a rendszerváltás után, 1993-ban emelkedett újra törvényi szintre a szakterület jogi szabályozása ${ }^{84}$ elmondható, hogy az 1903-ban kiadott migrációs törvény mérföldkő volt az idegenjog fejlődéstörténetében. ${ }^{85}$

A törvény tehát speciális szabályozást vezetett be a külföldiekre nézve. Ennek egyik alapvető rendelkezése volt, hogy a külföldi érkezését és távozását a szállásadó 24 órán belül köteles volt bejelenteni. Ennek elmulasztása kihágást valósított meg, melyet mind a szállásadó, mind a külföldi elkövethetett. Utóbbi a bejelentéshez szükséges adatok valótlan közlésével vagy elhallgatásával, előbbi a külföldi be nem jelentésével vagy azzal, ha az adatszolgáltatást megtagadó külföldit nem jelentette fel.

A községre érkező külföldi bejelentő lapot töltött ki, melyet aláírt. Ennek igazolószelvényét köteles volt magánál tartani és a hatóság felszólítására bemutatni. A fizető szálláshely tulajdonosa „Nyilvántartási könyv” vezetésére volt kötelezett, melyet összefüzött, lapszámozott és a rendőrhatóság által láttamozott formában szigorú alakiságok mellett naprakészen tartott. 
Az a külföldi, aki a bejelentési kötelezettségét nevének elváltoztatásával teljesítette vagy jogosulatlanul magyar utónevet vett fel, nem az állami anyakönyvekről szóló 1894 . évi törvény szerinti kihágást követte el, mint a magyar állampolgárok, ${ }^{86}$ hanem a külföldieknek a Magyar Szent Korona országai területén való lakhatásáról szóló az 1903. évi törvény szerint, vagyis idegenrendészeti jogszabály alapján volt büntethető. ${ }^{87} \mathrm{~A}$ vendégkönyvbe hiányosan vagy hamisan bejegyzett név, foglalkozás vagy lakóhely korábban is jogsértést valósított meg, de azt a közbiztonság elleni kihágás ${ }^{88}$ fogalomkörében kezelték és elkövetői nem csak külföldiek lehettek.

Az itt tartózkodó külföldieknek időről időre jelentkezniük kellett az idegenrendészeti hatóságoknál, melynek elmulasztása szintén kihágást valósított meg. A fenti ügyekben vidéken a föszolgabíró, az állami rendőrség müködési területén a rendőrség, Budapesten az egész fővárosra kiterjedő illetékességgel az V. kerületi rendőrkapitányság járt el. ${ }^{\mathbf{8 9}}$

A bejelentési kötelezettség később az ország egész területére kiterjedt a háború esetére szóló kivételes intézkedésekről szóló 1912. évi törvény szerint. ${ }^{90}$ A községbe érkező bejelentett idegenekről az elöljáróság nyilvántartást vezetett. Az idegenek ellenőrzésébe és nyilván-tartásába a vidék közbiztonságáért felelős csendőrség csak támogató jelleggel kapcsolódott be. Problémákat okozott, hogy a bejelentés és nyilvántartás folyamata teljes egészében a helyi igazgatási szervezet keretei között zajlott, így abba a csendör őrs nem tudott bekapcsolódni. A biztonsági kockázatot jelentő személyek ellenőrzésének felelőssége azonban a testületre hárult, ezért egy sajátos együttmüködési rendszer alakult ki az őrs-parancsnokok és a nyilvántartó szervezetek között. A nyilvántartási könyvet heti rendszerességgel a csendőrség rendelkezésére bocsátották, akik így információt szerezhettek a müködési területükön tartózkodó külföldiekröl és ellenőrizhették a tartózkodási szabályok betartását. ${ }^{91}$

A külföldiek bejelentésének és nyilvántartásának rendezésén túl az 1903. évi idegenjogi törvény további két jelentős rendelkezést is tartalmazott. Elsőként rendelkezett az idegenrendészeti hatóságokról, melyek kis- és nagyközségekben a főszolgabíró, Újpest és Rákospalota községekben a székesfővárosi rendőrség újpesti kerületi kapitánya, városokban a rendőrkapitányok, Budapest székesfövárosban a tanács, illetve meghatározott esetekben a székesfövárosi rendőrség fökapitánya, illetve helyettese, a határrendőrség hatósági területén pedig a határszéli rendőrkapitány.

A fővárosban a székesfővárosi rendőrség hatósági hatásköre azokra az ügyekre terjedt ki, melyekben a magát kellően nem igazoló, a maga és családja fenntartására szolgáló eszközökkel nem rendelkező, valamint az állami és közbiztonsági érdekeket sértő külföldiekkel szemben kellett fellépni.

Mivel a külföldiek rendészetével kapcsolatos adminisztratív teendők ellátása és idegenrendészeti normasértésekre történő intézkedés hagyományosan a közigazgatás, és nem a büntetőbíráskodás feladata volt, a törvény a jogsértések esetén eljáró rendőri büntetőbíróságokat is nevesítette. ${ }^{92}$

A magyarországi rendőri büntetőbíráskodás rendszere három szintű volt, alaki szabályait pedig a 1909-ben BM rendelet állapította meg. ${ }^{93}$ Általánosságban az elsőfokú rendőri büntetőbíróságok kis- és nagyközségekben a községi elöljáróság, a főszolgabíró, városokban a rendőrkapitány vagy a megbízott városi tisztviselö, Budapesten a kerületi rendőrkapitány vagy a kerületi elöljáró voltak. Másodfokú rendőri büntetőbíróságként kis- és nagyközségekben az alispán, városokban a rendőrkapitány. Harmadfokon a belügyminiszter és a Magyar Királyi Belügyminisztérium Kihágási Tanácsa volt illetékes. ${ }^{94}$ A rendőri büntetőbíráskodással csak személyt, és nem szervezetet lehetett megbízni. A rendőri büntetőbíró föszabály szerint személyesen bíráskodott és tevékenységi körében éppen olyan független volt, mint a bíróságok.

A városokban a személy- és vagyonbiztonságot veszélyeztető kihágásokban a rendőrkapitány, a közigazgatási vonatkozású kihágásokban a polgármester ítélkezett. Mivel a külföldiek rendészetével kapcsolatos kihágásokat a közrendészeti kihágások közé sorolták, rendőri büntetőbíráskodás szempontjából általában a rendőrkapitány volt illetékes.

A külföldieknek a Magyar Szent Korona országai területén való lakhatásról szóló 1903. évi törvény szerint ${ }^{95}$ speciálisan az idegenrendészeti kihágási ügyekben első fokon kis- és nagyközségekben a föszolgabíró, illetőleg a szolgabíró, Újpest és Rákospalota községekben 
a székesfővárosi rendőrség újpesti kapitánya; rendezett tanácsú és törvényhatósági joggal felruházott városokban a rendőrkapitány, illetőleg helyettese, ezek akadályoztatása esetén a tanács által megbízott tisztviselő járt el. A másodfokú eljárás kis- és nagyközségekben, valamint rendezett tanácsú városokban az alispán; Újpest és Rákospalota községekben a székesfővárosi rendőrség főkapitány vagy helyettese; törvényhatósági joggal felruházott városokban a tanács hatáskörébe tartozott.

Budapest, a külföldiek bejelentésére és jelentkezésére vonatkozó kihágások ügyében első fokon a kerületi kapitányság vezetője, másodfokon a székesfővárosi rendőrség főkapitánya, illetve helyettese járt el, míg a letelepedéssel kapcsolatos kihágási ügyekben első fokon az elöljáróság, másodfokon a tanács. A harmadfokú eljárás a belügyminiszter kizárólagos hatásköre volt. ${ }^{96} \mathrm{~A}$ határrendörség hatósági területén az elsőfokú rendőri büntetőbíráskodást a határszéli rendörkapitány gyakorolta.

A fenti jogszabályi alapokon nyugvó idegenrendészeti ellenőrzéseket mind a városi rendőrségek, mind a vidék útjait járó csendőr járőrök napi szolgálati feladatként végrehajtottak. A csendőrségi szakirodalom szerint a járőr a portyázás közben talált utasokra nézve „mindazon rendöri szabályok figyelemmel tartására volt köteles, melyek az idegenekre nézve fennálltak", vagyis az idegenrendészeti ellenőrzés a járör alapfeladatai közé tartozott. Fontos volt azonban, hogy alapos gyanú nélkül, csupán útlevele ellenőrzése miatt senkit nem lehetett megállítani. Akik azonban bármely okból gyanúsak voltak, azokat a járör igazoltatni volt köteles, például aki körözött személyre hasonlított, a csendőr közeledtére más irányba fordult, vagy ruházatán tiltott uszító jelvényt viselt, stb. ${ }^{97}$

A személyazonosság megállapítására különböző igazolványok és könyvecskék szolgáltak. Ilyen volt az Igazoló jegy, amely az Osztrák-Magyar Monarchia területén belül volt érvényes és kiváltása nem volt kötelező, de utazóknak ajánlott volt. Az iparosoknak kiadott Munkakönyv és a háztartásban dolgozók szolgálati könyve (Cselédkönyv) szintén nem voltak utazási okmányok, de az igazoltatáskor a személyazonosság megállapítására alkalmasak voltak. Az országban utazva alkalmi munkát vállalóknak Községi bizonyítványra volt szükségük, amely nélkül nem fogadhatták fel öket. A külföldiektől fő szabály szerint útlevelet kértek. Aki nem tudta azt előadni, de más okmányból személyazonossága megállapítható, további eljárásnak nem volt helye. Ha a külföldi semmilyen okmányt nem tartott magánál, akkor a tartózkodási helye szerinti községbe kellett kísérni, ahol tanúskodhattak kilétéről vagy táviratilag kellett illetékességi helyéről felvilágosítást kérni. ${ }^{98} \mathrm{Az} 1886$. IM rendelet ${ }^{99}$ szerint azonban az eljárás alá vont személyek állampolgárságát minden esetben megfelelően tisztázni és lehetőleg „okmányszerüen” megállapítani volt szükséges.

Az útlevél vagy úti igazolvány ekkor nem volt feltétlenül személyhez köthető. Ezen okmányokat a családfő részére állították ki és hatályuk a családtagokra is kiterjedt. Csak 1899-től írták elő, hogy a családtag nevét, korát és rokonsági fokát is be kell jegyezni. Az okmánynak a fénykép nem volt kötelező része, így az útlevelek ellenőrzése komoly feladat volt. ${ }^{100}$ A személyazonosság és az állampolgárság igazolására szolgáló okmány fogalmát az útlevélügyről szóló 1903. évi törvény rendezte, ${ }^{101}$ ezt követően az ellenőrző hatóságok és fegyveres testületek is pontosították saját belső szabályzóikat az erre alkalmas okmányok vonatkozásában.

Külön kihívás volt azon külföldiek felderítése, akik nem jogszerütlen tartózkodásukkal, hanem büntetendő cselekmények elkövetésével veszélyeztették a közcsendet és biztonságot. A nemzetközi gonosztevők közé sorolták a menekülő és a letelepedett idegen bünözőket, a külföldi csavargókat és hivatásos koldusokat, az utazó bűnözőket, valamint a nemzetközileg üldözött bủncselekmények elkövetőit. A menekülő és letelepedett bünelkövetők vagy utazó bünözők figyelemmel kísérésére és felderítésére elsősorban közbiztonsági szempontból volt fontos, azonban a nemzetközi büncselekmények elkövetői körében a szélhámosok és csalók mellett a leánykereskedők tevékenységét kiemelten kezelték. ${ }^{\mathbf{1 0 2}}$

Az idegenrendészeti ellenőrzés és nyilvántartás rendszere a közigazgatási és rendvédelmi szakmai igények, majd a háborús készülődés miatt egyre komplexebbé vált. A külföldiek rendészetével kapcsolatos fejlődő felügyeleti igény azonban olyan ellenőrzési eljárások kidolgozásához vezetett, melyek számos, ma is alkalmazott, a schengeni határellenőrzési gyakorlatba illeszkedỏ alapelvben élnek tovább. 


\section{Idegenrendészet a két világháború között}

A két világháború közti idegenrendészeti szabályozás dualista alapokon nyugodott és azokat továbbfejlesztve folyamatos és egységes egészet alkotott az első világháború előtti szabályrendszerrel. A háborús veszély és a kivételes hatalom gyakorlása során bevezetett intézkedések sem voltak képesek megingatni a külföldiek rendészetének elvi alapjait, a háborút követő káosz azonban merőben más helyzetet teremtett. A magyarországi tanácsköztársaság idegenrendészeti szabályozása sem terjedelmében, sem minőségében nem érte el azt a szintet, ami külön tárgyalás tárgyává tehetné. A rövid fennállása alatt megalkotott normák a rendszer bukását követően hatályukat vesztették és újra az I. világháborút megelőző rendelkezések léptek életbe trianoni békediktátum állampolgársági rendelkezéseivel kiegészítve.

Az alapvető szabályrendszert továbbra is a külföldieknek a Magyar Szent Korona országai területén való lakhatásáról szóló 1903. évi törvény tartalmazta, ${ }^{103}$ melyet később rendeleti szintü szabályozás egészített ki. Korábban nem tapasztalt problémát okozott a területelcsatolásokat követően az új határokon kívül rekedt népesség helyzete. A trianoni békediktátum 1921. évben való törvénybe iktatása alapján az állampolgársági helyzetet tisztázó 1921. évi miniszterelnöki rendelet és kiegészítései rendezték ${ }^{104}$ az elcsatolt területeken élők állampolgárságával kapcsolatos kérdéseket, így az állampolgárság elvesztését, optálását és visszahonosítás általi visszanyerését. Az 1879. évi honossági törvény értelmében ${ }^{105}$ aktív és passzív magatartásokkal volt lehetséges a magyar állampolgárság elvesztése. Passzív magatartásnak számított például a hivatalos okokon kívüli 10 éves külföldi tartózkodás, amely automatikusan a honosság elvesztéséhez vezetett. A trianoni békediktátum következtében azonban nagy számban és hirtelen jelentkeztek a hontalansággal kapcsolatos problémák és vitás állampolgársági kérdések, melyek rendezésében nem lehetett a korábbi jogszabályokra támaszkodni. Ezek elbírálásakor a belügyminiszter azt vette figyelembe, hogy a döntéssel érintett személynek hol volt illetőségi községe 1921. VI. 26-án. ${ }^{106}$ A községekröl szóló 1886. évi törvény ${ }^{107}$ értelmében a magyar állampolgárnak községi illetőséggel kellett bírnia. Az optáltak és visszahonosítottak éppen amiatt veszítették el magyar állampolgárságukat, mert illetőségi községük az új határokon kívülre került. Az illetőségi község kijelölésére az állampolgársági eljárás lezárását követően a belügyminiszter volt illetékes. Az illetőségi hely kijelölése iránti indokolt kérvényt annak a városnak vagy községnek az elöljáróságánál kellett benyújtani, amelynek kijelölését kérték. ${ }^{108}$

$\mathrm{Az}$ opció és visszahonosítás útján korábbi állampolgárságukért folyamodó magyarokon kívül más nemzetiségek tagjai is megpróbáltak állampolgárságot szerezni. Különösen jellemző volt ez Bosznia-Hercegovina polgáraira, akik az orosz-török háborút lezáró 1878. évi berlini szerződés alapján török állampolgárnak számítottak. Bár a szerződés az OsztrákMagyar Monarchiát bízta meg a terület megszállásával és igazgatásával, a lakosság hivatalosan törtök honosságú maradt. Bosznia-Hercegovina annektálását követően, az 1909. II. 26án az Osztrák-Magyar Monarchia és Törökország között kötött egyezmény alapján a bosnyákok tartományi illetőséget szerezhettek, ez azonban nem jelentette, hogy a magyar korona alatt lett volna illetőségi helyük, így magyar állampolgárságot a trianoni békediktátum előtt és után is csak a magyar állampolgárság megszerzéséről és elvesztéséről szóló 1879. évi törvény általános szabályai szerint nyerhettek, opció által nem. ${ }^{109}$

A megcsonkított Magyarországra visszatérni szándékozó korábbi magyar állampolgárok tömegeinek kezelésére 1920-ban ME rendelettel ${ }^{110}$ létrehozták az Országos Menekültügyi Hivatalt a Békeelőkészítő iroda „B” csoportjának keretében. ${ }^{111}$ A megszállott területekről való beutazók ellenőrzéséről szóló 1920 . évi miniszterelnöki rendelet ${ }^{112}$ és a végrehajtására kiadott 1921. évi ME rendelet ${ }^{113}$ kimondta, hogy minden beköltöző köteles volt jelentkezni a Beköltözőket Ellenőrző Kirendeltségek egyikén. A kirendeltségek Lőkösházán, Biharkeresztesen, Szegeden és Hidasnémetiben, később Szobon és Budapesten álltak fel. A kéttagú vizsgálóbizottság pozitív döntése esetén léphetett be az országba a beköltözni szándékozó (egy tagot a BM, egyet az OMH rendelt ki). A helyzet normalizálódását követően az OMH 1924. VI. 30-án beszüntette tevékenységét. Ezt követően a hivatal korábbi hatáskörben a népjóléti és munkaügyi miniszter járt el. ${ }^{114}$

A közbiztonsági helyzet és a társadalmi rend stabilizálódását követően — bár a külföldi 
fogalma alatt sokszor korábbi magyart értettek — az idegenrendészet visszatért korábbi szabályrendszeréhez és alapelveihez. A szükségszerü szigorítások és a békeidőszak nyújtotta lehetőségek a szakterület fejlődését eredményezték, amely leginkább a külföldiek ellenőrzésének napi feladataiban volt tetten érhető.

Az idegenrendészeti ellenőrzések gyakorlati végrehajtása kapcsán a külföldieknek az ország területén való lakhatásáról szóló törvény végrehajtási rendeletében foglaltakban ${ }^{115} \mathrm{a}$ két világháború közötti jogi környezet egyik sarokköveként vezetett be új elemeket. Eszerint minden külföldi 2 hónapot tartózkodhatott hazánkban, melyet a tartózkodási idő lejárta előtt kérelmezett tartózkodási engedéllyel hosszabbíthatott meg. A kereső tevékenység folytatásához a beutazás előtt beszerzett úgynevezett kincstári engedély vagy utólag kérelmezett munkavállalási engedély volt szükséges. ${ }^{116}$

Az 1903. évi törvény ${ }^{117}$ adós maradt a külföldi meghatározásával, melyet csak a külföldieknek az ország területén való lakhatásáról szóló törvény végrehajtásáról szóló végrehajtási rendelet fogalmazott meg. ${ }^{118} \mathrm{Az} 1925$-ös BM rendelet hatályba lépését követően tehát egyértelmüen külföldinek tekintettek mindenkit, aki „a fennálló jogszabályok értelmében nem magyar állampolgár." A kérdés azonban bonyolultabb volt ennél. Az elcsatolt területekről származó személyeket a külföldiekre vonatkozó kötelezettségek terhelték és ezek következetes ellenőrzésével igyekeztek ösztönözni őket állampolgárságuk rendezésére. E személyek esetében nem a születési helyet, hanem az illetőségi helyet kellett figyelembe venni, vagyis akinek illetőségi helye továbbra is magyar területen volt, annak a magyar állampolgárságot nem kellett külön „optálnia”.

Főszabály szerint tartózkodási engedélyt az kaphatott, aki nem akart lakóhelyet létesíteni hazánkban. Érvényességi ideje egy év lehetett, melyet csak a belügyminiszter által kiállított tartózkodási engedély léphetett túl kivételes esetekben. A munkavállalási célú tartózkodási engedély kiadása kizárólag a belügyminiszter hatásköre volt. Aki le akart telepedni lakhatási bizonylatot kaphatott, amely szintén egy évig jogosított magyarországi lakhatásra, de érvényessége meghosszabbítható volt. ${ }^{119}$

A tartózkodási hely bejelentése továbbra is az idegenrendészet egyik alappillére maradt. Az önkormányzati rendőrségek államosításáról szóló 1919. évi ME. rendelet ${ }^{120}$ rendelkezéseinek kiegészítéseként a bejelentkezési kötelezettségről szóló1930. évi ME. rendelet ${ }^{121}$ a bejelentési kötelezettséget békeidőben, rendes viszonyok között is kiterjesztette az ország egész területére. Ennek érvényre jutása érdekében az1930-ban kibocsátott BM. rendelet minden magyar állampolgár számára elöírta a lakóhely és elköltözés bejelentését, melyet a városokban továbbra is a bejelentő hivatalokhoz vagy a rendőrkapitányságokhoz, vidéken a jegyzöhöz kellett megtenni. ${ }^{122}$

A budapesti rendőr-fökapitány az a fővárosi rendőrségről szóló 1881 . évi törvény ${ }^{\mathbf{1 2 3}}$ felhatalmazása alapján 1931-ben elrendelte a lakók betüsoros névjegyzékének vezetését a több lakásos házak esetében, melyet a házfelügyelő vezetett a név, születési hely, foglalkozás és a lakás számának naprakész feltűntetésével. Ebbe valamennyi be- és kijelentést be kellett vezetni a rendőrségi bejelentést igazoló „Bejelentési igazolószelvény” adatai alapján. A betelt könyveket meg kellett őrizni és a hatóság rendelkezésére bocsátani. A jegyzékkel egyezö, folyamatosan aktualizált adatokat a ház kapujában olvasható magasságban és kellően megvilágítva ki is kellett helyezni. A fenti szabályoknak a lakók vagy a háztulajdonosok részéről történő megszegése kihágást valósított meg.

A névjegyzék pontos vezetése természetesen nemcsak a külföldiek tartózkodási helyének nyomon követését szolgálta, hanem a fővárosi állandó lakosságának és a vidékről érkezőknek a hatóságok általi előtalálását is segítette. A Budapest állandó és ideiglenes lakosai közötti különbségtétel és pontos nyilvántartás nemcsak a bevándorlás, hanem a kivándorlás ellenőrzését is szolgálta. A budapesti illetőségü személyek egyszerübben és gyorsabban juthattak útlevélhez, és ezt a helyzetet mások is igyekeztek kihasználni. A hatóságok üldözték a bejelentésekkel kapcsolatos visszaéléseket, különösen ha azok valamilyen jogtalan előny megszerzésére irányultak. Így ha a háztulajdonos a nála meg nem szállt vidéki személyeket budapesti lakosként bejelentette, és így azok útlevélhez jutottak a hatóság megtévesztésével, a közokirat hamisítás valósított meg. ${ }^{24}$ Hasonló volt a helyzet, ha a tulajdonos egy külföldi személyt jelentett be kizárólag a tartózkodási vagy letelepedési engedé- 
lyezési eljárás gyorsítása érdekében.

A külföldiek lakhatását a külföldieknek a Magyar Szent Korona országai területén való lakhatásáról szóló 1903. évi törvény ${ }^{125}$ általános szabályi mellett a törvényt módosító 1930 . évi törvény ${ }^{126}$, továbbá azok végrehajtásáról szóló 1930 . évi BM. rendelet ${ }^{127}$ szabályozták és egészítették ki.

A bevezetett új rendelkezések a korábbinál világosabb és célhoz kötöttebb engedélyezési rendszert teremtettek, melyben az ellenőrző hatóságok, a rendőrség és a csendőrség feladatai is jobban meghatározhatóak voltak. A tartózkodási idő, bejelentési kötelezettségek, valamint a különböző tartózkodásra jogosító engedélyek céljuknak megfelelő felhasználása mellett nagy hangsúlyt kapott a külföldiek munkavállalásának ellenőrzése is. Ez a közbiztonsági érdekek érvényre juttatása mellett a hazai munkaerőpiac védelmét is szolgálta.

Az 1925. VIII. 1. után beutazott külföldiek csak munkavállalási engedély birtokában folytathattak kereső tevékenységet. Ezek a személyek kizárólag az engedélyben megjelölt munkakörben, községben, munkaadónál, időtartamban és feltételekkel vállalhattak munkát. Bármelyik körülmény megváltozásával új engedélyért kellett folyamodni. A más háztartáshoz szegődött házicselédek vagy nevelőnők és munkaadóik például a rendelkezést azzal próbálták kijátszani, hogy az alkalmazottat rokonként vagy próbaidősként jelentették be. Aki nem munkavállalási engedélyt, hanem más igazoló okmányt mutatott be, és ebben munkavállalást megengedő bejegyzés nem volt, akkor azt kellett vélelmezni, hogy az a számára tiltva van. Az ellenőrzések támogatására a korabeli szakirodalom - különösen a Csendörségi Lapok - rendszeresen foglalkozott az idegenrendészeti kérdésekkel, sőt mai terminológia szerinti „kockázatelemzéseket” is készített az ellenőrzéseket végzők számára. Az engedély nélküli munkavállalást valószínüsítette például, ha az ellenőrzött külföldi származási országában is napszámból vagy alkalmi munkákból élt, illetve magyar vendéglátói is ezzel keresték kenyerüket.

A külföldi engedély nélküli munkavállalása kihágást valósított meg, amelyért a munkaadót és a munkavállalót is felelősség terhelte. E kihágások többsége a vidéki területeken realizálódott, hiszen itt számos külföldi mezőgazdasági munkás találhatott magának megélhetést. A jogsértést legtöbbször észlelő és intézkedő csendőrök ekkor a kihágási feljelentés mellé úgynevezett közigazgatási jelentést is készítettek, amelyben a külföldi ügyében eljáró rendőrbírón kívül a közigazgatási szervezetek ügyintézőinek figyelmét is felhívták a körülményekre (például arra, hogy az adott területen a hazai munkaeröpiac veszélybe került-e).

A szakirodalom külön figyelemre érdemes csoportba sorolta még a külföldi artistákat és cirkuszi mutatványosokat, a „bolgár kertészeket”, a házaló bosnyák és székely árusokat, valamint a vándorló drótosokat és köszörüsöket is. A különböző kockázati kategóriák ellenőrzéséhez különböző módszereket alkalmaztak. A mezőgazdasági idénymunkásokat („,bolgár kertészeket") például a munkatelepeken az összes munkás szigorú igazoltatásával évente kétszer kellett ellenőrizni, melyeket április második felében és szeptemberben kellett végrehajtani az idénymunkákhoz igazodóan. ${ }^{\mathbf{1 2 8}}$

Az ellenőrzési, engedélyezési és nyilvántartási feladatok egységes és központosított végrehajtására 1930-ban létrehozták a Külföldieket Ellenőrző Országos Központi Hatóságot, a KEOKH-t. ${ }^{129}$ A külföldiek ellenőrzését a föszolgabírók és a KEOKH a korábbi gyakorlatnak megfelelően elsősorban a bejelentő és nyilvántartó lapok alapján végezték, így a vidéki területeken a csendörség, a városokban a rendőrség volt továbbra is a gyakorlati végrehajtásra elsődlegesen hivatott testület.

A folyamatosan fejlődő szabály- és szervezetrendszer egyre hatékonyabban volt képes ellenőrizni az országban tartózkodó külföldieket és a beutazási vagy tartózkodási szabályok ellen vétőkkel szemben szigorúan lépett fel.

A bejelentési, jelentkezési vagy vendégkönyv-vezetési kötelezettség megsértése, az engedély nélküli letelepedés vagy munkavállalás alap esetben továbbra is kihágást valósított meg, melyek körét a külföldieknek az ország területén lakhatásáról szóló 1903. évi ${ }^{130}$ és az 1930. évi ${ }^{131}$ törvények végrehajtásáról szóló 1930 . évi belügyminiszteri rendelet ${ }^{132}$ bővítette. A rendelet alapján akár 15 napi elzárással is büntethető kihágást valósított meg az a külföldi, aki az országban jogosulatlanul tartózkodott, illetőleg lakott, engedély nélkül munkát, alkalmazást vállalt, kereső tevékenységet folytatott, vagy jelentkezési kötelezettségének nem tett eleget. A kihágás csupán pénzbüntetéssel volt büntethető, ha a szabályszegés kisebb súlyú 
vagy pusztán adminisztratív jellegü volt. Ez megvalósulhatott, ha az érkezés bejelentésére vonatkozó bejelentőlapot a külföldi nem írta alá, vagy ennek igazolószelvényét a hatóság vagy a hatósági közeg felhívására nem mutatta be. Hasonló volt a helyzet az az ideiglenes itt tartózkodásra vonatkozó hatósági intézkedés, lakhatási engedély, elismervény, vagy munkavállalási engedély hatósági felhívásra történő be nem mutatása vagy a munkavállalási engedély feltételeinek megszegése esetén is.

A rendelet szankciót határozott meg a külföldit jogellenesen foglalkoztató személyekkel szemben. Az ő tevékenységük elzárással büntethető kihágást valósított meg, ha a munkára, vagy szolgálatra alkalmazott külföldi munkavállalási tilalom hatálya alatt állt, és pénzbüntetéssel büntethető szabályszegést, ha külföldi alkalmazottját olyan munkakörben foglalkoztatta, amelyre a munkavállalási engedély nem vonatkozott. Külön felelösség terhelte a munkaadót, ha a külföldi alkalmazottak névjegyzékét nem vezette megfelelően vagy azt a hatósági közeg felhívására nem mutatta vagy szolgáltatta be.

Az ország területéről jogerősen kiutasított vagy az ország területéről való eltávozásra jogerösen kötelezett külföldi, aki az eltávozásra kitüzött határidő alatt az ország területét nem hagyta el, szintén elzárással volt sújtható, a tiltott határátlépés elkövetője azonban csak pénzbüntetésre számíthatott. Az a külföldi, aki a határátlépés ellenőrzésével megbízott hatósági közeg felhívására a tartózkodási hely illetékes hatóságánál a megérkezését követő 24 órán belül nem jelentkezett, vagy az utólagos vízum beszerzésére vonatkozó utasításnak nem tett eleget, szintén szankcionálható volt. ${ }^{133}$

A háborút követő zürzavaros időkre és az azt követő bizalmatlanságra jellemző módon új intézkedések és korlátozások is bevezetésre kerültek a külföldiekkel szemben. Azt a külföldit, aki az állami vagy társadalmi rend, illetve a közbiztonság szempontjából káros lehetett a - az 1920-ban kibocsátott belügyminiszteri — ${ }^{134}$ szerint rendöri felügyelet alá lehetett helyezni, mely során mozgásában a rendőrhatóság engedélyéhez kötve korlátozták és legalább heti egyszer, de akár napi két alkalommal is személyes jelentkezési kötelezettséget írtak elő számára. ${ }^{135}$ E szabályok megszegése a főszolgabíró vagy rendőri hatóság hatáskörébe tartozó, kihágást valósított meg. ${ }^{136}$

Akinek a megfigyelése vagy rendőri felügyelet alá helyezése nem volt elégséges a magyar állam érdekeinek védelme szempontjából, azt természetesen továbbra is kiutasították. Az 1903-as migrációs törvény ${ }^{137}$ adta lehetőségeken túl bizonyos esetekben a kiutasítás elrendelése kötelező volt, így a munkanélküli, lakóhellyel nem rendelkező, bünös életvitelü külföldit, aki a magyar társadalom békéjét és rendjét veszélyeztette ki kellett utasítani. Az árdrágító visszaélés vétségben bünösnek talált külföldit ki kellett utasítani és a visszatéréstől örökre eltiltani. ${ }^{138} \mathrm{Az}$ állami és társadalmi rend hatályosabb védelméröl szóló 1921. évi törvény szerint ${ }^{139}$ a magyar nemzet megbecsülése ellen irányuló egyes büncselekmények esetén szintén kiutasításnak és a visszatéréstől való örökös eltiltásnak volt helye. A törvénycikkben felsorolt társadalmi rendet veszélyeztető magatartások mellett „aki a katonaság intézménye, a magyar fegyveres erö, a m. kir. csendörség vagy a m. kir. államrendörség ellen gyülöletre vagy ezek szolgálati fegyelme ellen izgat s törvényes rendelkezések ellen engedetlenségre hív fel", jogerős elítélését követően soha nem térhetett vissza Magyarországra. A szigorú rendelkezést súlyára tekintettel csak a bíróságok alkalmazhatták. ${ }^{140}$

Hasonló volt a helyzet a hadviselés ellen elkövetett büncselekmények, különösen a hadiszállítások körül elkövetett visszaélések megtorlásáról szóló 1915 . évi törvényben ${ }^{141}$ nevesített büntettek, valamint a fizetési eszközökkel elkövetett visszaélésekről szóló 1922. évi törvényben szabályozott büntetendő magatartásainak eseteiben is. ${ }^{\mathbf{1 4 2}}$

A kiutasítás körüli eljárást a két világháború között is alapjaiban az 1908. évi igazságügyminiszteri rendelet szabályozta. ${ }^{143}$ A kiutasított külföldieket a belföldi toloncolás szabályainak megfelelően kísérték a határra, vagyis a mai értelemben is használt hatósági kényszerrel történő kitoloncolás valósult meg.

Az egyre komplexebb szabályrendszer betartatásában és a külföldiek ellenörzésében a helyhatóság saját közegein túl az állami rendőrségnek és a világháborút követően újjáalakult csendőrségnek is egyre nagyobb szerep jutott. Az idegenrendészeti ellenőrzés rendszere szinte azonos volt a háború elötti gyakorlattal, de hatékonysága és gyakorisága növekedett. $\mathrm{Az}$ ellenőrzést végző szervezetek (helyi szinten a csendőr őrs parancsnoka vagy a rendőrka- 
pitány) a tudomásukra jutott külföldieket a legközelebbi járőrszolgálatban felkerestették és személyazonosságukat valamint tartózkodásuk célját megállapíttatták. Ebből a célból az elözö belföldi tartózkodási hely szerinti rendőrhatóságot vagy csendör örsöt is megkereshették. Mivel a külföldinek csak abban az esetben kellett személyesen megjelennie a községi elöljáróságnál, ha letelepedési engedélyért kívánt folyamodni, egyéb esetben pedig minden bejelentési kötelezettségét adatlapon teljesítette közvetett módon, az igazoltatott külföldiek esetében a járör nem minden esetben tudta megállapítani a kötelezettségek teljesülését. Külön figyelmet kaptak azok a külföldiek, akik lakhatási bizonylatot vagy letelepülési engedélyt kaptak. Öket nemcsak a főszolgabíró, hanem az illetékes rendőrkapitányság vagy csendőr őrs is nyilvántartotta és rendszeresen ellenőrizte. A pályaudvarok, vendéglátóhelyek, szállodák ellenőrzésére időről időre „razziát” szerveztek, mely során valamennyi ott talált külföldit igazoltattak. ${ }^{144}$

A tartózkodási engedélyt nyert vagy egyéb bejelentett külföldiek ellenőrzésére a hatósági közeg előre fel tudott készülni, tájékozódni a beszélt nyelvről és tolmácsról gondoskodni, a személyt megfigyelni vagy érdeklődni felőle. Más volt a helyzet azonban az út közben, lakott területen kívül igazoltatott külföldiekkel. A harmincas évek elején egyre több külföldi szerencsevadász és világutazó tünt fel az utakon, akik új kihívás elé állították a velük legtöbbször kapcsolatba kerülő csendőrséget, ezzel ösztönözve új módszertan kidolgozását.

Az igazoltatás közben a csendöröknek például nem szabadott egymás között magyarul az utasról beszélni, mivel az ellenőrzött személy sok esetben eltitkolta magyar nyelvtudását. Éppen ezért ha a csendőr beszélte is az utas feltételezett nyelvét, elöször magyarul kellett megszólítania, majd idegen nyelven, így felmérhette ennek lehetőségét. ${ }^{145}$ A külföldiekkel való érintkezés során problémát okozott a világnyelvek ismeretének hiánya. A leggyakoribb ismert idegen nyelv a német volt a csendőr-legénység körében, azonban francia, angol vagy olasz nyelvismerettel szinte senki nem rendelkezett. A minimálisan szükséges kommunikáció biztosítására még két részből álló nyelvi füzetecskék gondolata is felmerült, mellyel a csendör „a külföldi rendelkezésére állhatott." ${ }^{146}$ A nyelvismeret hiánya azonban nem vezethetett az intézkedés meghiúsulásához. A hatályos csendőrségi Szolgálati Utasítás szerint a csendör a felszólítását és a „törvény nevében” szavakat elöször magyarul mondta ki, majd ha az intézkedéssel érintett személy nyelvét ismerte - más nyelven is. Azonban ha más nyelven nem beszélt, elég volt a magyar nyelvü felszólítás is, melynek eredménytelensége esetén jogosult volt további intézkedéseket tenni és „,kényszereszközöket” használni. ${ }^{147}$

A növekvő idegenforgalom kapcsán nemcsak a nyelvismeret okozott problémát a mélységi ellenőrzések során. A korábbinál nagyobb felkészültséget igényelt az útiokmányok vizsgálata is. A korszak „kockázatelemzései” szerint az igazi világjáró okmányai rendben voltak, megfelelő mennyiségü pénzeszközzel rendelkezett, fizető szálláshelyen szállt meg nagyobb városokban, nappal mozgott és csak akkor ment gyalog, ha valamit meg akart tekinteni. Ezzel szemben a külföldi „csavargó” általában nem belépő állomáson, hanem átkelő állomáson lépett be az országba, ahol az egyszerübb ellenőrzés miatt nem derült fény a létfenntartásához szükséges anyagi fedezet hiányára. Úti célja általában valamely balkáni állam volt, kerülte a nagyobb településeket, gyalog közlekedett és az ingyenes szállásokat kereste. A szakirodalom külön megemlíti, hogy ezek az ,álvilágutazók” az utazás céljának igazolására saját készítésủ albumot mutattak be, melyben feljegyzett élményeik és fényképeik mellé igyekeztek hivatalos hatósági bejegyzéseket és pecséteket szerezni „emlékül”. Igazoltatásuk alkalmával aztán e bélyegzőlenyomatokra hivatkozva állították, hogy korábban már ellenőrzésre kerültek. A csendőrnek e bejegyzésekre és föleg a fényképekre külön figyelmet kellett fordítania, mivel a hidakról, repülőterekről és vasútvonalakról készített képek a kémkedés gyanúját is felvetették. ${ }^{148}$ A nem kívánatos, közbiztonsági veszélyt és szociális terhet jelentő külföldiek kiszürése tehát alapvető fontossággal bírt, ezért a csendőr minden általa foganatosított intézkedés alkalmával köteles volt körültekintően megállapítani az érintett személyazonosságát és egyéb körülményeit. ${ }^{149}$

A személyazonosság és állampolgárság megállapítása elsődlegesen útlevél alapján történt, melynek folyamata a dualizmuskori ellenőrzési metódus továbbfejlesztését jelentette, de alapvető lépései meglehetős hasonlóságot mutatnak a mai határellenőrzés folyamatába épített útlevél-ellenőrzéssel is. $\mathrm{Az}$ általános gyakorlat szerint az útlevelek ellenőrzése a 
borítólap szemrevételezésével kezdődött, melynek színéből a kiállító országra lehetett következtetni. Ezt követte a fénykép és a fényképet biztosító bélyegzők vizsgálata, majd a személyazonosítás. Az útlevélbe bejegyzett nevet és adatokat a külfölditől meg kellett kérdezni, ki kellett mondatni. A név ellenőrzésében a keresztnevek külföldön szokásos írásmódját tartalmazó, és a két világháború között még mindig hatályos a keresztneveknek a születési anyakönyvekbe idegen neveken is bejegyezhetőségére vonatkozó 1895 . évi belügyminisztériumi rendelet ${ }^{150}$ melléklete nyújtott segítséget. Ha az útlevélen „,vakarás vagy javitás" volt észlelhető, úgy a tulajdonosát elő kellett vezetni és személyazonosságát más módon meg kellett állapítani. ${ }^{151}$

A személyazonosság és a név helyes megállapítását követte a nyomozókulcsban történő priorálás és annak megállapítása, hogy a külföldi mikor és hol lépett az ország területére, valamint nem lépte-e túl az engedélyezett tartózkodási időt. Az útlevél utolsó lapoldalának bejegyzéseit is érdemes volt szemügyre venni, mivel a konzulátusok és követségek itt jegyezték be, ha a pénzzavarba került külföldit segélyben részesítették. Ez a körülmény jelezhette a csendőrnek, hogy a külföldi a továbbiakban már nem rendelkezik megfelelö anyagi fedezettel, amely miatt végső soron kiutasítható volt. A külföldi útlevelek bejegyzéseinek vizsgálatához - kellö számban rendelkezésre álló mintaokmány hiányában - javasolt volt, hogy az örskörletben tartózkodó megbízható külföldiek útlevelét a csendör kérje kölcsön, és egy szintén megbízható, a nyelvet jól beszélő segítővel fordíttassa le, készítsen segédletet a jövőre nézve.

A bejelentési kötelezettség teljesítését az ellenőrzés során be- vagy kijelentő lappal igazolhatta a külföldi, melyet a csendör szintén megvizsgált. Javasolt volt a csomagok ellenörzése is, mivel az álvilágutazók a tapasztalatok szerint könyöradomány gyüjtésböl (például képeslap árusításból) tartották fenn magukat. Erre utaló jelek esetén kihágási eljárásnak volt helye. ${ }^{152} \mathrm{Ha}$ a csendör a mélységben ilyen személyt talált, vagy tiltott határátlépésen tetten ért valakit, de vámjövedéki kihágás gyanúja nem merült fel, a külföldit „csavargásban leletnek" tekintette és a közveszélyes munkakerülésről szóló 1913. évi törvény alapján ${ }^{153}$ mint közveszélyes munkakerüléssel gyanúsítottat tényvázlat szerkesztése mellett közvetlenül a közigazgatási hatóságnak, mint rendőri büntetőbíróságnak adta át. ${ }^{154}$ A rendőri büntetőbíró a hasonló esetekben általában élt a kiutasítás lehetőségével is, vagyis a kártékonynak tekintett idegeneket egyszerü és gyors eljárással távolíthatták el az országból.

Az ellenőrzések során a csendőrnek arra is figyelemmel kellett lennie, hogy az igazoltatott személy korábban nem került-e kiutasításra vagy a visszatéréstől eltiltásra. Ezt az útlevélben található bejegyzésekből vagy gyanú esetén előállítását követően tudta megállapítani.

A fentiekből is látható, hogy a külföldiek rendészetére vonatkozó szabályok betartásának ellenörzése komoly felkészültséget és szakmai tapasztalatot igényelt különösen annak fényében, hogy az ellenőrző személyeknek nem álltak rendelkezésére a ma már megszokott számítógépes adatbázisok és nyilvántartások. A fejlődő ellenőrzési módszertan ellenére azonban az idegenrendészet még az 1930-as évek közepén sem volt külön tantárgy a csendör őrs-parancsnoki vagy járőr-vezetői tanfolyamon és a rendôri képzésekben sem jelent meg. ${ }^{155}$

\section{A közigazgatás szerepe az idegenrendészetben}

A közigazgatás idegenrendészeti feladatainak tárgyalása és a kapcsolódási pontok feltérképezése előtt szükséges áttekinteni a magyar igazgatási struktúra három kulcsfontosságú szintjét: a föispán, az alispán és a (fö)szolgabíró helyét és szerepét.

A föispán a kormány képviselője volt a törvényhatósági közigazgatásban, akit a belügyminiszter előterjesztésére és ellenjegyzése mellett a király nevezett ki. Állása így politikai természetü volt és bármikor elbocsáthatták hivatalából. Hatásköre kettős: a törvénykezési és katonai hatóságok és hivatalok kivételével egyrészt a törvényhatóság területén levő kormányközegek, királyi hatóságok müködésére, másrészt a törvényhatóság által teljesített autonóm és állami közigazgatásra terjedt ki. Joga volt az állami szervezetek eljárását ellenőrizni, azoktól konkrét esetekre vonatkozólag felvilágosítást követelni. A föispán volt a törvényhatósági közgyülés elnöke is. Teendői a következő szempontok szerint csoportosíthatók a föispáni „rendes hatalom” körében:

- általános ellenőrzési felügyeleti teendők; 
- rendelkezés, rendelet, utasítás kibocsátás a felügyeleti, ellenőrzési jogkörön belül;

- fegyelmi hatalom gyakorlása;

- szervezeti és kinevezési, kijelölési, áthelyezési, helyettesítési, beosztási teendők.

Ha a törvényhatóság vagy annak első tisztviselője nem teljesítette a kormányrendeletek végrehajtására vonatkozó kötelességét, a minisztérium felhatalmazhatta a föispánt, hogy a törvényhatóság szükséges tisztviselőivel és közegeivel közvetlenül rendelkezhessék. Ez volt a föispán rendkívüli hatalma. A fentiekböl is látható, hogy a politikai funkciók gyakorlása mellett komoly végrehajtó hatalom is összpontosult a föispán kezében, ami a tárgyalt időszak közjogi szabályozásában azt eredményezte, hogy bizonyos jogoktól (pl. a karhatalom kirendelésének jogától) idővel megfosztották.

A föispán szerepe az idegenrendészeti rendszer müködtetésében tehát közvetett volt, az állami akaratot - és sok esetben a politikai akaratot - testesítette meg a külföldiek ellenőrzésében. Feladatának jelentősége abban állt, hogy a vármegye területén az idegenjogi szabályozásból adódó keretek között mindig az állami érdekekhez igazította a külföldiekkel szembeni hatósági magatartást és szankció-alkalmazást. Vagyis ha az állam érdeke úgy kívánta bizonyos jogsértéseket elkövető külföldiekkel elnézőbb volt a közigazgatás (pl. hiányszakmák képviselöivel), míg máskor ugyanazon jogsértések elkövetőit szigorúbban szankcionálták (pl. magas belföldi munkanélküliség esetén nagyobb számban éltek a kiutasítás lehetőségével az alkalmi munkából élő külföldiekkel szemben). A föispánnak e befolyásolási képessége természetesen nem egyedi ügyekre, hanem sokkal inkább a hatóságok által általánosan követendő és elvárt gyakorlatra terjedt ki.

Az alispán a főispán helyettese volt már a nemesi vármegyében is. Az alispán a politikai színtéren mozgó fơispán helyett a vármegye professzionális közigazgatási funkcionáriusaként tevékenykedett. A kinevezett föispánnak nem volt alárendelve, hanem önállóan intézte a megyei közigazgatás ügyeit. A föispán vele szemben - ahogy az egész vármegyei közigazgatással szemben is - csak ellenőrzési jogot gyakorolt.

Az alispán az általános rendőri büntetőbíráskodásban másodfokú rendőri büntetőbíróságként müködött a kis- és nagyközségekben, az idegenrendészeti kihágások kapcsán ezt a funkciót a kis- és nagyközségekben, valamint rendezett tanácsú városokban látta el. Mint a közigazgatás fejének már közvetlen ráhatása volt a közigazgatás idegenrendészeti tevékenységére.

A főszolgabíró a járás első tisztviselője volt, a vármegyei törvényhatósági bizottság a járás élére élethosszig választotta. A magyar közigazgatás egyetemes jellegü szervezete volt, eljárt köz- és állategészségügyi, anyakönyvi, erdészeti, gyám, gondnoksági, házassági, cseléd, ipari, népoktatási, vadászati, vásári, vízjogi stb. ügyekben és kihágási bíráskodást is gyakorolt. A föszolgabíró a községi közigazgatás közvetlen felügyelőjeként elnökölt egyes községi képviselőtestületi közgyüléseken is. A községi közegekhez rendeleteket intézhetett és a nem engedelmeskedő vagy hanyag községi tisztviselökkel szemben rendbírságolási és fegyelmi joga volt. Az alispán közvetlen felügyelete alatt müködött, tőle kapta utasításait. Bírói hatóságot is gyakorolt a kisebb polgári peres ügyekben való eljárásról szóló törvény szerint az egyszerübb peres ügyekben, valamint büntetőbíróként a közigazgatási hatóságok hatásköréhez utalt kihágások eseteiben.

A föszolgabíró az 1903. évi idegenjogi törvény szerint elsőfokú idegenrendészeti hatóságként müködött a kis- és nagyközségekben, vagyis valamennyi bejelentési és engedélyezési ügyben közvetlen intézkedési és döntési jogköre volt. Az általános kihágási és az idegenrendészeti kihágási ügyekben első fokú rendőri büntetőbíróságként funkcionált a kis- és nagyközségekben, vagyis a külföldiek rendészetére vonatkozó normasértések esetén az ő kezében volt valamennyi szankció lehetősége a kihágási pénzbírságtól a kiutasításig és a viszszatéréstől eltiltásig. Idegenrendészeti intézkedései érvényre juttatása érdekében felhívással élhetett a helyi, és megkereséssel a magasabb szintű csendőrségi szervekhez, melyek akár fizikai kényszerrel (az akkori szóhasználat szerint karhatalom kiállításával) is teljesítették azt. ${ }^{156}$

E közigazgatási struktúra nagyban meghatározta a tárgyalt időszak idegenrendészeti eljárásrendjét és gondolkodását, valamint az engedélyezés, a nyilvántartás, és a szankcióalkalmazás elveit. Helyzetéből adódóan a közigazgatás találkozott legtöbbször idegenrendészeti ügyekkel és a legális bevándorlás teljes adminisztrációját is ez a szervezetrendszer végezte el. A rendvédelmi 
testületekhez telepített elsőfokú idegenrendészeti hatósági jog-körök szükségszerüen inkább az illegális bevándorlásra, a tartózkodási szabályok megsértésére, vagy a külföldiekkel szembeni kényszerintézkedések alkalmazására koncentráltak. A fegyveres testületek közül a Magyar Királyi Csendőrség, mint a vidék közbiztonságáért általánosan felelős szervezet, valamint a Magyar Királyi Határrendőrség, mint speciális és szakosított hatóság feladatrendszere igényel külön tárgyalást.

\section{A Magyar Királyi Csendőrség szerepe az idegenrendészetben}

A csendőrtestület idegenrendészeti feladatait két csoportba sorolhatjuk: egyrészt a dualizmus időszakának határszéli csendőrsége által megvalósított speciális feladatokra, másrészt a két világháború közötti időszakban a mélységi ellenőrzések végrehajtására.

A csendőri szervezet a határszéli szolgálat 1891 -es megszervezésével ${ }^{157}$ került valójában kapcsolatba a külföldiek rendészetével, bár az akkori értelemben vett idegenrendészeti feladatok fennállása folyamán folyamatosan jelentkeztek a napi szolgálatokban. A határmenti szolgálat speciális volt a szervezeten belül nemcsak feladatait, de azok szervezését tekintve is. A határszéli őrsök közbiztonsági szolgálatuk mellett látták el a zöldhatár őrzését egy speciális szaktiszt (kikülönített törzstiszt) közvetlen irányítása alatt, aki érvényesítette a kerületparancsnokság utasításait és koordinálta azok végrehajtását. A szakterület számos újítást vezetett be a hatékonyabb müködés érdekében. Az 1912-es átszervezés nyomán például elöször alkalmaztak kutyákat a határörizetben szolgálati állatként a tiltott határátlépést elkövetők nyomainak felkutatására, elfogására és örzés-védelmi feladatokra. ${ }^{158}$

A határszéli szolgálati ág feladatait részletesen először az 1912. évi szolgálati utasítás tartalmazta, melyben hangsúlyos részt kapott a külföldiek bejelentésére és lakhatására vonatkozó szabályok ellenőrzése továbbá határőrizeti témában alkotott BM. rendeletek ${ }^{\mathbf{1 5 9}}$ szerint, az embercsempészés és leánykereskedelem megakadályozása, valamint a kivándorlás szabályozásáról szóló 1909 . évi törvény és végrehajtási rendelete ${ }^{\mathbf{1 6 0}}$ alapján. A csendőrség végezte az úgynevezett kishatárforgalmi rendszerben utazók ellenőrzését is. Kishatárforgalmi útiokmányok kiváltására a határvonaltól számított 40 km-es sávban lakók voltak jogosultak, melyekkel a szomszéd ország szintén $40 \mathrm{~km}$-es mélységéig utazhattak. Ennek az engedélynek a beszerzése volt a legegyszerübb, mivel a kiállításra jogosult önkormányzati hivatal csak a legritkább esetben nézett utána, hogy az igénylö valóban a határ 40 km-es körzetében lakik-e. ${ }^{161} \mathrm{Az}$ okmánnyal kapcsolatos visszaélések megakadályozása volt a csendőrjárör feladata. Külön elbánás alá esetek a kettős birtokosok, illetve azok, akiknek a birtokán a határvonal áthaladt. E birtokok tulajdonosai és müvelői birtokukon, illetve az általuk müvelt területeken bárhol átléphették a határt és terményeiket, állataikat is átvihették, de a birtok határán kívülre csak útlevéllel léphettek. ${ }^{162}$ Az adott korszakban tehát a határ közelében megfelelő okmányok nélkül talált külföldi nem volt ritka jelenség és ellenőrzésük komoly felkészültséget igényelt.

Az „idegenek” ellenőrzésének egyre részletesebb szabályait és eljárásrendjét a testület Szolgálati Utasításaiban, a mai szolgálati szabályzatok korabeli megfelelőiben is tetten érhetjük.

Az 1881. évi Szolgálati Utasítás - a Magyar Királyi Csendőrség első „szolgálati szabályzata" - még csak arra vonatkozóan tartalmazott rövid rendelkezéseket, hogy a csendőr szolgálata során a magányosan és rossz hírben álló csárdákat és az ott talált gyanús idegeneket ellenőrizze. A portyázás közben talált utasokra nézve az idegenrendészeti szabályok ellenőrzése kötelező volt, azonban ok nélkül feltartóztatni - az Osztrák-Magyar Monarchián belüli szabad mozgás biztosításának elve szerint — senkit nem lehetett. A csendőrnek a vámhatár átlépése tilos volt, azonban az Osztrák-Magyar Monarchia másik államának szomszédos kerületeibe bizonyos feltételek mellett üldözhette a jogsértést elkövetőket. ${ }^{163}$

Az 1900. évi Szolgálati Utasítás a határszéli szolgálat kapcsán már kiemeli az útlevélrendészeti szabályok elsődleges ellenőrzését, valamint a csavargók, kémek vagy „,a biztonságra egyébképen veszélyes egyének" kiszürését. A magyar-román határt útlevél vagy igazolvány nélkül átlépő személyeket az illetékes elsőfokú rendőrhatóság elé kellett állítani. ${ }^{164}$

Az 1912. évi Szolgálati Utasítás az előbbi rendelkezések megtartása mellett külön „Határszéli szolgálati utasitás” résszel bővült, ami a dualizmus korának legteljesebb szabályrendszerét foglalta össze a témában. A külön utasítás igénye a Magyar Királyi Határ- 
rendőrség határrendőri őrségeinek 1912. V. 01-ei megszüntetésével merült fel, amikor — a csendőrségre egyébként is érvényes jogszabályok fenntartása - mellett a „határrendöri külső végrehajtó szolgálatot" a Magyar Királyi Csendőrség átvette. Az utasítás előremutató módon megkülönböztet közvetlenül a határvonal mentén szolgálatot teljesítő őrsöket és bizonyos határforgalmi tranzit- és csempészútvonalak mentén elhelyezkedő mélységi örsöket. A határszéli örsök teendői között markánsan helyet kaptak az idegenrendészeti feladatok. Ezek különösen a külföldiek bejelentésére és lakhatására vonatkozó szabályok, valamint a kitiltott, magukat igazolni nem tudó gyanús egyéneknek ellenőrzéséből, a kerítés és leány-kereskedés megakadályozásából, a határszéli vasúti és gőzhajó állomásokon az államrendészeti, közbiztonsági és közegészségügyi szabályok betartásának ellenőrzéséből, útlevélvizsgálatból és a határszéli szállodák, vendéglők, kocsmák, kávéházak és egyéb nyilvános helyek figyelemmel kíséréséből állt. Külön feladatkört képezett a tiltott kivándorlás megakadályozása. ${ }^{165}$

A csendőrség a fentieket nemcsak önállóan, hanem a határszéli rendőrkapitányságok és kirendeltségek megkeresésére is teljesítette. A határrendi vagy idegenrendészeti jogsértések elkövetőit is a fenti hatóságoknak adták át, vagyis a csendőrség csupán végrehajtó erő volt.

A külföldiek bejelentésére és lakhatására vonatkozó 1903. évi törvény és a végrehajtására kiadott utasítás ${ }^{166}$ alapján ellenőrizték, melynek végrehajtását az utasítás részletesen tárgyalta. A csendőrségnek kötelessége volt a határszéli rendőrkapitányságok müködési területén kívül meggyőződni arról, hogy a szállodákban és magánházakban megszállt külföldiek érkezésének és távozásának bejelentésére vonatkozó szabályokat betartják-e. Magánházakba azonban csak indokolt esetekben léphettek be, elsősorban a bejelentési szabályokkal kapcsolatos mulasztás gyanúja esetén. A gyártelepeken alkalmazott ${ }^{167}$ és a népszerü fürdőhelyeken turistaként tartózkodó ${ }^{168}$ külföldiekre külön rendészeti szabályok vonatkoztak, melyeket szintén ellenőriztek.

A kitiltott, rendes foglalkozással vagy keresettel nem bíró csavargókat és a „közbiztonságra veszélyes egyén benyomását keltö" utazókat a mélységi területeken is fel kellett tartóztatni, és ha magukat igazolni nem tudták a határról visszautasítani. A visszautasításra okot nem adó, de gyanús utasokról megfigyeltetésük végett jelentést kellett tenni annak a közigazgatási hatóságnak és csendőr őrsnek, melynek területén a külföldi tartózkodni vagy megszállani szándékozott.

Az Oroszországból kiutasított nem magyar alattvalók, továbbá a „szerb majomtáncoltatók" Magyarország területén nem tartózkodhattak, ezért feltalálásuk esetén a csendőr járőr a kitoloncolás foganatosítása céljából elővezette őket. A szomszéd vagy más idegen államból kivándorolt külföldiek vasúti vagy vízi átutazása csak szabályszerủ útlevéllel, és megfelelő anyagi fedezettel (vagyis minden 10 éven felüli személynél a vasúti vagy hajójegyek leszámításával legalább 400 korona) volt megengedhető.

Különösen fontos „erkölcsrendészeti” feladatnak tekintették a határszéli vasúti vagy hajóállomások utasainak feltünés nélküli megfigyelését a leánykereskedelem megakadályozása céljából. A megfigyelést a személyes szabadság megóvása és különösen a nők erkölcsi érzületének és jó hírnevének tiszteletben tartása mellett kellett végrehajtani úgy, hogy kivándorlás ürügye alatt utaztatott megtévesztett fiatal lányokat a csempészektől megmenthessék.

Útlevelek vizsgálata tekintetében általában a határforgalom ellenőrzésének, az útlevelek vizsgálatának, az úti igazolványok kiállításának, a forgalmi adatok gyüjtésének tárgyában, illetve a kivándorlásra és a visszavándorlásra vonatkozó statisztikai adatok szolgáltatása tárgyában kiadott 1904. évi BM. rendelet határozványai voltak irányadók. ${ }^{\mathbf{1 6 9}}$ A határátlépéskor végrehajtott útiokmány-ellenőrzésen kívül az utasítás a határközeli mellékutakon közlekedő külföldiek ellenőrzésére is részletes szabályokat állapított meg. A külföldi igazoltatásakor a csendőr az útlevél és más igazolványok érvényességének megállapítása után személyazonosítást hajtott végre a bejegyzett személyleírási adatok alapján a fentebb már ismertetett módon. Szükség esetén az utastól vett aláírásmintát is össze kellett hasonlítani az útlevélben szereplővel. Ezután következett a belépés helye szerinti határállomás bélyegzőlenyomatának ellenőrzése.

Az ország mélységében talált útlevéllel nem rendelkező külföldieket a csendör járőr az 
illetékes rendőrhatóság elé állította, azonban akiket az országból való kilépésük során igazoltatott és személyazonosságukat más arcképes igazolványból, munkakönyvből, cselédkönyvből, stb. képes volt megállapítani, a továbbutazásban nem szabadott megakadályoznia. Ha a személyazonosság nem volt megállapítható vagy más személy nevére kiállított okmány felhasználásának gyanúja merült fel, az eljárásrend ugyanaz volt, mint a mélységi elfogás esetében. A más névre szóló vagy hamisított útleveleket el kellett kobozni.

A kivándorlás céljából Magyarországon át tömegesen utazó külföldieknek megszakítás nélkül kellett tranzitálniuk. Az ilyen csoportok útleveleit a határállomásokon elvették, jegyzékbe foglalták és a vasúti kalauznak vagy hajó személyzetének átadták. Az átutazás során a csoport tagjainak mozgására a csendőr járörnek kiemelt figyelmet kellett fordítania. A kivándorlás ellenőrzésében elsősorban a titkos kivándorlási ügynökök és a jogosulatlan kivándorlást elősegítők kinyomozása jelentett feladatot, valamint az, hogy kivándorlás céljából útlevél és hajójegy nélkül az országot senki ne hagyja el. A leánykereskedelem megelőzéséhez hasonlóan figyelemmel kellett kísérni azt is, hogy a kivándorlók nem „csábítás” áldozatai-e.

A fentiekből is látható, hogy az 1912-es utasítás felölelte az idegenrendészet és határterületeinek csaknem teljes vertikumát. A szabályozás mérföldkőnek tekinthető a külföldiek rendészeti ellenőrzése terén és meghatározta a következő évtizedek csendőrségi gondolkodásmódját és eljárásrendjét a témában. A később kiadott szolgálati utasítások egyértelmüen az itt lefektetett alapokra építve tárgyalták az idegenrendészeti ellenőrzések rendszerét.

A két világháború között az idegenrendészeti feladatok átértékelődtek, a külföldi és belföldi idegenek felügyeletének azonos alapelveit felváltotta a kizárólag nem magyar állampolgárokra vonatkozó rendészeti szabályok ellenőrzése. Az 1924. évi Szolgálati Utasítás továbbra is kötelezővé tette a nyilvános helyiségek rendszeres idegenrendészeti célú ellenőrzését és az ott talált külföldiek személyazonosságának, foglalkozásának és itt tartózkodásuk céljának megállapítását. A csendőrnek ezen felül ismernie kellett a müködési területen letelepedett nem magyar állampolgárságú személyeket, figyelnie kellett életmódjukat, valamint azt, hogy jelentkezési és bejelentési kötelezettségeiknek eleget tettek-e. Ha arra vonatkozó információ merült fel, hogy valahol be nem jelentett külföldi tartózkodott, arról mindig személyes ellenőrzéssel kellett meggyőződni. Az idegenrendészet felértékelődését jelezte az is, hogy a szállodai vendégkönyveket lehetőleg naponta ellenőrizni kellett a portyázások során, sőt a nagyobb idegenforgalmú helyiségekben az őrs-parancsnok személyesen is köteles volt megjelenni az elöljáróságnál ilyen célból. Az illetékes hatóságtól ideiglenes tartózkodási engedélyt nyert külföldiek iratainak érvényességi idejét az ellenőrzések során fel kellett jegyezni, a lejáratot követően pedig személyes ellenőrzéssel tisztázni, hogy a személy távozott, vagy tartózkodási engedélyét meghosszabbította-e? ${ }^{\mathbf{1 7 0}}$

A tudatosabb, következetesebb ellenőrzések térnyerése az 1927. évi Szolgálati Utasításban folytatódott, miszerint az örsparancsnok kötelessége volt, hogy az örskörletben tartózkodó külföldiek ellenőrzését megszervezze, valamint figyelemmel kísérje, hogy a külföldiek illetőleg szállás- vagy munkaadóik a bejelentési és nyilvántartási kötelezettségeiknek pontosan eleget tesznek-e? Ezt rendes szolgálattal kellett biztosítania, de indokolt esetben külön erre a célra vezényelt járört is kiküldhetett. Ez volt az első szabályzatban is rögzített említése a kifejezetten idegenrendészeti célú járőr vezénylésének. A külföldi ellenőrzése továbbra is történhetett a közigazgatási hatóságok megkeresésére, de saját észlelés alapján hivatalból is. A szokásos ellenőrzési eljárások a tartózkodás céljának és körülményeinek vizsgálatával egészültek ki, valamint a létfenntartáshoz szükséges anyagi fedezet meglétére is kitértek. Szükség esetén a járör „bizalmas módon” is puhatolhatott a külföldi után. Ezt különösen akkor kellett megtenni, ha a külföldi bejelentette távozását, de gyanú volt arra, hogy az országot nem hagyja el. ${ }^{171} \mathrm{~A}$ fenti szabályozás állandó maradt és az 1941. évi Szolgálati Utasítás is változatlan formában átvette. ${ }^{172}$

Összességében elmondható, hogy a Magyar Királyi Csendőrség a felállításakor végrehajtott általános idegenellenőrzési feladatoktól nagy utat tett meg az idegenrendészeti ellenőrzések speciális szabályrendszerének kidolgozásáig. A téma kezdetben mint érdekesség jelent meg a szakirodalomban, és csak kis számú érdeklődő tiszt és altiszt ismerte behatóan a külföldiekre vonatkozó szabályokat. A szervezet feladatai egyébként a közigazgatási hatóságok tevékenységének támogatására szorítkoztak. Az állami szabályozási igény fejlődése a 
közigazgatás és a rendvédelmi szervezetek specializálódását eredményezte, melyek az idegenrendészet tartalmának fogalmi változásaival létrehozták belső szabályzóikat és kiképezték szakszemélyzetüket. Nem volt ez másként a Magyar Királyi Csendőrség szervezetében sem, ahol a napi szolgálati feladatok részévé tették a külföldiek ellenőrzését és a rájuk vonatkozó szabályok betartatását. A feladatot nemcsak a határszéli vagy közbiztonsági szolgálat járörei látták el, de a később megszervezett szolgálati ágak (ezt a kifejezést a vizsgált időszakban még nem használták) is kaptak szakterületükhöz igazodó idegenrendészeti feladatokat. Az 1929-ben létrehozott közlekedési csendőrség például a külföldi gépjármüvezetők menetokmányainak ellenőrzése mellett minden közúti ellenőrzés alkalmával vizsgálta a jogszerü tartózkodás feltételeinek meglétét is.

A Magyar Királyi Csendőrség tehát képes volt megfelelni a külföldiek ellenőrzésére vonatkozó állami elvárásoknak és egyre hatékonyabb szürőrendszer müködtetésével garantálni az idegenrendészeti szabályok érvényesítését. Tevékenységük egyaránt segítette a legális utazás és jogszerü belföldi tartózkodás gyakorlását és védte a hazai munkaerőpiacot, társadalmi rendet és szociális ellátó rendszert a külföldről érkező fenyegetésektől.

\section{A rendőrség szerepe az idegenrendészetben}

A polgári magyar állam határőrizeti modelljének lényegét tekintve a nyugat-európaihoz sorolható, hiszen békeidőben nem katonai alakulatok, hanem rendvédelmi testületek valósították meg a határok őrizetét. ${ }^{173}$ Egységes, külön erre a célra létrehozott szervezet azonban nem létezett a kiegyezést követő évtizedekben. A nemzeti rendvédelmi testületek határmenti alakulatai láttak el az alaptevékenységükhöz kapcsolódó határőrizeti részfeladatokat, így szükségszerüen valamennyi részfeladat egyik szervezetnél sem jelentkezett. Szükséges volt azonban egy olyan hatósági jogkörökkel felruházott állami szervezet létrehozása, amely összehangolta a határőrizeti teendőket és bizonyos szakfeladatokat maga is ellátott. Ez a testület volt a Magyar Királyi Határrendőrség. ${ }^{174}$ A Magyar Királyi Határrendőrségről szóló törvényt már 1903-ban elfogadták, ${ }^{175}$ müködését azonban csak 1906. I. 15-én kezdte meg. Ekkorra a törvényi felhatalmazás mellett a tevékenységet részleteiben is szabályozó végrehajtási rendelet is megjelent. ${ }^{176}$

A határrendőrség polgári fegyveres őrtestület volt, amely a városi rendőrségek mintájára szerveződött. Az első világháború közeledtével később szükségessé vált a katonai határőrizet rendszerébe való integrálása és helyének tisztázása a katonai viszonyok között, ezért ennek részeként 1911-ben meghatározták az egyes határrendőri rangoknak megfelelő katonai rendfokozatokat. Ez azonban a szervezet közigazgatási kötődését nem befolyásolta, vagyis továbbra sem volt katonai szervezetnek tekinthető. ${ }^{177} \mathrm{~A}$ határrendőrségi hatáskör a határátlépő állomások kijelölése és hatáskörük szabályozása tárgyában alkotott 1923. évi BM rendeletben meghatározott községek területére korlátozódott. ${ }^{178}$ A Magyar Királyi Határrendőrségnek békeidőszakban nem voltak katonai feladatai. A háború időszakára azonban - a katonai határőrizetre történő áttérés részeként — a Magyar Királyi Határrendőrség is kapott feladatokat a kivételes hatalom időszakára vonatkozóan, a testület jellegének megfelelően. ${ }^{179}$

A magyar határőrizet történetét a témával foglalkozó legjelentősebb kutató dr. PARÁDI József három szakaszra osztja. Az első, bevezető időszak 1867-1903. között főként a tapasztalatszerzés jegyében telt, amely az önálló magyar határőrizet létrehozásához vezetett. Az 1903-1912. közötti időszakban létrejött és stabilizálódott a Magyar Királyi Határrendőrség szervezete helye és szerepe a közigazgatási struktúrában. Az utolsó periódus 1912-1919. között már a katonai határőrizet megvalósulásáról és a kivételes hatalom intézkedéseiről szólt, melyekben a szervezet részt vett illetve támogatott. ${ }^{180}$

A határrendőrség létrehozása összességében szükséges volt a századelő magyar idegenrendészeti rendszerének továbbfejlesztéséhez és müködése nagyban hozzájárult a külföldiekre vonatkozó szabályok és kötelezettségek érvényre juttatásához.

A Magyar Királyi Határrendőrség demonstrálta a történelmi Magyarország egységét, valamint a határőrizeti és idegenrendészeti gondolkodásban a magyar vezetést szimbolizálta az uralkodó osztrák körök irányába. A szervezet szerény létszámmal kezdte meg müködését, az uralkodó 1905. októberében 11 határrendör-kapitány, 18 határrendőr-fogalmazó, 9 határrendőr-segédfogalmazó, 10 határrendőr-fogalmazó gyakornok, 19 határrendör-felügyelö, 21 
határrendör hivatali segédtiszt, 50 határrendőr biztos és 22 hivatalszolga, vagyis összesen 160 fő kinevezését hagyta jóvá. ${ }^{181}$ A személyi állomány az első világháború kitörésekor 451 fö volt. ${ }^{182}$

A szervezet a belügyminiszter által 1905-ben megállapított keretek között 11 kapitánysággal és 24 kirendeltséggel szerveződött. 1908. és 1912. között a struktúra határrendőr örségek felállításával egészült ki, de az 1912-es átszervezést követően az őrségek feladatait a határszéli csendőrség erői vették át egyes határforgalom-ellenőrzési feladatokkal együtt. A kapitányságok száma ezzel párhuzamosan 17-re, a kirendeltségeké 41-re nőtt. A szervezet legsürübben a szerb és a román határokon, valamint Bukovina és Galícia irányában települt. A legkevesebb szervezeti egység Horvátország, Ausztria és Morvaország irányába épült ki. ${ }^{183}$ A határrendőrség müködési területét és diszlokációját 41 rendelettel módosították fennállása során. Megalakulásakor 25 vármegyére, az Osztrák-Magyar Monarchia felbomlásakor pedig 30 vármegyére terjedt ki rendőrhatósági illetékessége. ${ }^{184}$

A határrendőrség feladatai sokrétűek voltak és a határőrizet, valamint az idegenrendészet teljes vertikumát felölelték. Elsődleges feladata volt természetesen a határon átkelők figyelemmel kisérése, a határ mentén felmerülő, államrendészeti szempontból fontos eseményekről való tájékozódás és az észleltek közlése az illetékes hatósággal. Ennek fontos része volt a kémkedés megakadályozása, az esetleges kémeknek letartóztatása is. Ennek érdekében eredményesen együttmüködött a haderő felderítő szervezeteivel és határszéli csendőrség alakulataival. A hírszerző munka támogatásában szerzett érdemek elismeréseként a hadtesttörzsek mellett müködő felderítő fóállomások több ízben tettek javaslatot határrendőr vezetők elismerésben részesítésére. ${ }^{185}$

Ezek mellett fellépett az árucsempészet megakadályozása érdekében és közremüködött az erre hivatott közegek munkájában. A vámhatósági és pénzügyőri feladatok támogatása mellett saját hatáskörben ellenőrizte a fegyverek, lőszerek és hadiszerek kivitelét vagy behozatalát, valamint más tiltott eszközök és tárgyak forgalmát. Az állam katonai képességeit nemcsak a hadianyagok vonatozásában, de hadköteles egyének kiszökésének megakadályozása által is védte. Ezen felül feladata volt a szomszéd állam lakói részéről minden erőszakos támadás meggátlása, különösen pedig a katonai védmüvek, az ország határának megjelölésére szolgáló határjelek, jelzők, katonai vagy polgári hatóság által felállított földmérési jelek megrongálásának, megsemmisítésének, vagy megváltoztatásának megakadályozása és feljelentése.

A határrendi és határőrizeti teendők mellet a szervezet leghangsúlyosabb feladatai az idegenrendészet terén jelentkeztek. Nemcsak a külföldiek bejelentésére és lakhatására vonatkozó szabályok betartása, a kitiltott, „rendörileg kifogás alá esö” és magukat igazolni nem tudó gyanús egyéneknek az állam területétől távoltartása, hanem a határszélen letartóztatott és a toloncszabályok rendelkezései alá eső külföldiek kitoloncolása és a külföldről kitoloncolt magyar állampolgárok átvétele is feladatát képezte. Mint az idegenrendészeti ellenőrzésekben érintett más szervezetek, a határrendőrség is kiemelten kezelte a „nőcsempészet” és leánykereskedelem megakadályozását is. A határrendőrség közegei a határszéli vasúti és gőzhajóállomásokon éppúgy rendszeresen megjelentek, mint a szállodákban, vendéglőkben, kávéházakban és egyéb nyilvános helyeken.

A fentiek mellett az útlevél-kötelezettség alá eső államokkal közös határszakaszokon a szervezet határforgalom-ellenőrzési feladatokat is ellátott és saját hatáskörben végezte a határátkelési igazolványok kiállítását. A fenti komplex feladatrendszer első fokú rendőri büntető bíráskodási jogkörrel egészült ki, amely az ellenőrzésen túl az azonnali szankcióra is képessé tette a testületet.

A határrendörség e feladatokat bel- és külszolgálati teendőkkel látta el. A belszolgálat a hivatali tevékenységeket jelentette, melyeket a hét minden napján teljesítettek. A kapitánysági hivatal hétköznapokon hat, vasárnap és ünnepnapokon négy órán át fogadott ügyfeleket. Ezt egészítette ki az állandó ügyeleti szolgálat. A külszolgálat portyázó szolgálatból, álló szolgálatból és mozgó (pl. vonat vagy hajó) ellenőrzésből állt.

A testület viszonya a közigazgatás más szerveihez és a társ rendvédelmi testületekhez sajátos volt. Szolgálati tekintetben a belügyminiszter alárendeltségébe tartozott, illetékességét maga döntötte el. A gyakorlatban a határrendőri szolgálatban észlelt, nem a határrenddel 
összefüggő jogsértések elkövetöit az arra illetékes hatóságnak átadta, míg a más hatóságok és szervek által észlelt határrenddel összefüggő eseményeket átvette.

A határrendör kapitányságok müködési területe az államhatártól számított 40 km-es sávra terjedt ki. Az ezen belül található városok rendőrkapitányságai külön megkeresés nélkül jelentést tettek a határrendőri hatáskörbe tartozó jogsértésekről, részt vettek a külföldi toloncjáratok szállításában, és igény esetén nyomozást folytattak a határrendőr-kapitányság megbízásából. A müködési területen levő csendőri erők szintén kötelesek voltak támogatni a határrendőrség munkáját karhatalom nyújtásával, megfigyelések végrehajtásával és nyomozások segéderejének biztosításával. ${ }^{186} \mathrm{~A}$ határrendőrség nagyban támaszkodott a csendőrség fegyveres erejére az idegenrendészeti ellenőrzések végrehajtásában, a két testület egymáshoz való viszonya azonban nem mindig volt kellően átlátható. 1893-tól a csendőrség határmenti erői a szolgabírói kirendeltségek irányításával müködtek, de szolgálatukat önállóan, a felettes csendőri szerv utasításai szerint szervezték. 1906. után, amikor a szolgabírói kirendeltségek feladatait a határrendőrség vette át, az együttmüködés nehézkesebb lett, mivel az új szervezet konkrét jogszabályi felhatalmazás nélkül alárendelt szervezeti elemekként utasította a csendőrőrsöket. A helyzet 1912-re tisztázódott, amikor a határrendőr őrségek és a csendőrség tevékenységének párhuzamosságait megszüntették és egyértelmüvé tették a feladatokat. A csendőrség külföldieket ellenőrző tevékenysége is ekkor nyert új szabályozást és megerősítették a testület szerepét az idegenrendészet területén.

A határrendör kapitányságok saját végrehajtói feladataik mellett ellenörzési jogköröket is gyakoroltak. Saját kirendeltségeiket negyedévente, a határőrizetben és idegenrendészetben résztvevő más hatóságok és szervek munkáját félévente ellenőrizték. A szervezet nemcsak a szakmai munka ellenőrzésében, de a gyakorlat egységesítésében is vezető szerepre törekedett. Ennek keretében útmutatásokat és ajánlásokat adott a társszerveknek. 1907-ben a határrendőrség, kivándorlás, útlevélügy és külföldiek rendészetének kérdését már külön Határrendészeti Kézikönyv tárgyalta. ${ }^{187} \mathrm{~A}$ mủ előfutára volt a későbbi évtizedek széles körủ szakirodalmának, amely az 1930-as évekre teljesedett ki. ${ }^{188}$ A határrendőrség, majd a rendőrség szakemberei részt vettek a szakirodalom bővítésében és támogatták a téma tudományos igényü feldolgozását is.

A két világháború között az önkormányzati rendőrségek országos államosításával vált indokolttá a határrendőrség beintegrálása az állami rendőrség szervezetébe. Az integráció nem szakmai okokból vagy elégtelen müködés következtében történt, hanem a megváltozott állami struktúra és közigazgatási szemlélet eredményeként. A városokban a külföldiek ellenőrzésének feladatait a városi rendőrségek ezt követően Magyar Királyi Állami Rendőrség, ${ }^{189}$ majd 1931-től a Magyar Királyi Rendőrség ${ }^{190}$ végezte. A határrendőrség feladatai szakterületi szinten kerültek integrálásra, így azok megegyeztek a korábbi feladatrendszerrel. Az idegenrendészeti ellenőrzések a csendőrség végrehajtási gyakorlatának megfelelöen történtek azzal a különbséggel, hogy a közigazgatási szervekkel folytatott együttmüködés a városokban szorosabb volt, mint vidéken.

Összességében az állami rendőrségek tevékenysége meghatározó volt az idegenrendészeti szervezetrendszer kialakítása és működtetése szempontjából. A Magyar Királyi Határrendörség és jogutódai sokkal inkább közigazgatási szemlélettel kezelték a külföldiek rendészetét, mint a csendőrség. Következetes ellenőrzéseik, a hatósági jogkörök átgondolt gyakorlása és a rendőri büntetőbíráskodás azonnali szankcióalkalmazási lehetősége által a szervezetek képesek voltak hatékonyan fellépni a tartózkodási szabályok ellen vétőkkel szemben, egyúttal garantálni a külföldiek jogkövető többségének jogait és szabadságát.

\section{Összefoglalás}

Az idegenrendészet alapvető fogalmi ismérve, hogy kizárólag nem magyar honosságú személyekkel szemben indítható és csak abban az esetben, ha a külföldi beutazása vagy tartózkodása ellentétes a vonatkozó jogszabályi rendelkezésekkel. A külföldiekkel kapcsolatos rendészeti tevékenység a rendészet egy sajátos típusa, amely - a rendészet általános meghatározásából kiindulva - a külföldi magatartásából adódóan megzavart rend helyreállítására irányul. ${ }^{191} \mathrm{E}$ tevékenységet a közigazgatás szervezetei és a rendvédelmi testületek fejtették ki a tárgyalt időszakban és fejtik ki napjainkban is. Éppen ezért nem lehet az idegenjog normáit 
önmagukban, csupán rendelkezéseiket áttekintve vizsgálni. Szükséges annak tárgyalása is, hogy a külföldiekkel kapcsolatba kerülő ellenőrző hatósági közeg milyen elvek és eljárási protokollok nyomán végezte tevékenységét, jogsértés felfedése esetén milyen intézkedéseket tett és végső soron hogyan lépett fel a veszélyt jelentő idegenekkel szemben. Ebben a megközelítésben az idegenjog normaanyagába tartozik minden olyan rendelkezés, amely a jogalanyok állampolgárságára tekintettel jogállásukat a honos (belföldi) személyektől eltérően szabályozza. Éppen ezért szükséges az olyan rendelkezések vizsgálata is, melyekben a külföldiek csavargással, a szociális háló megterhelésével vagy a munkaerőpiac veszélyeztetésével vétenek a magyar társadalom rendje ellen, nem pusztán az adminisztratív szabályok megsértésével. Az ilyen magatartások egy része kívül esik a polgári közigazgatás hatáskörén, ezért a bűnüldöző szervezetek tevékenysége megkerülhetetlenül a témakör része.

Az idegenjog szükebb megközelítésben a külföldiekkel kapcsolatos igazgatási és rendészeti kérdések összefoglalására koncentrál, vagyis a külföldiek beutazásával, tartózkodásával, letelepedésével, illetve a nem jogszerüen tartózkodó külföldiekkel szembeni eljárással foglalkozik. ${ }^{192} \mathrm{Az}$ idegenrendészeti hatóság jogkörében eljáró föszolgabíró nem lett volna képes önállóan fellépni valamennyi normasértő magatartással szemben, így hatósági jogkörök telepítésére volt szükség egyes rendvédelmi szervezetekhez (így a rendőrségekhez), míg más testületek és szervek hatósági jogok hiányában csupán az ellenőrzések gyakorlati megvalósítását támogatták (pl. a csendőrség).

Összességében megállapítható, hogy a hatékony idegenrendészeti ellenőrző rendszer müködtetése a törvényhatósági közigazgatás a katonailag szervezett, valamint a polgári fegyveres örtestületek folyamatos és szoros együttmüködését követelte meg. A dualizmus korszakának egyedi esetekre korlátozódó, eseti jellegü idegenrendészeti intézkedéseit egyre inkább a részleteiben is szabályozott, az állami érdekekkel és célokkal összhangban álló szabályrendszer és eljárásrend váltotta fel. A községekről szóló törvény ${ }^{193}$ és az 1879. évi állampolgársági törvény ${ }^{194}$ után a Magyar Királyi Csendőrség országos megszervezése, ${ }^{195}$ majd határszéli „,szolgálati ágának” felállítása ${ }^{\mathbf{1 9 6}}$ jelentett mérföldkövet a külföldiek ellenőrzésének rendszerében. Az 1903. évi migrációs törvénycsomag ${ }^{197}$ elfogadása, majd a Magyar Királyi Határrendőrség felállítása ${ }^{\mathbf{1 9 8}}$ jelentette a második fordulópontot mind a norma-, mind a szervezetrendszer szempontjából. Az I. világháborút követően a trianoni békediktátum ${ }^{199}$ és az általa jelentkező állampolgársági problémák jelentettek új kihívást, melyek a Magyar Királyi Csendőrség újjászervezésével és az idegenrendészeti feladatokat magába olvasztó Magyar Királyi Állami Rendőrség megalakulásával ${ }^{200}$ jelentették a harmadik lépcsőfokot a szakterület fejlődésében. Az 1925. évi szabályozást ${ }^{201}$ kiegészítő 1930. évi idegenrendészeti jogszabálycsomag ${ }^{202}$ és a KEOKH megszervezése képviseli a tárgyalt időszak utolsó nagy periódusát, amely a békeidejü idegenrendészet átalakulásával és az 1939. évi szervezeti és szabályozási törvénymódosításokkal ${ }^{203}$ ért véget.

Minden fejlődési szakaszban megjelentek olyan módszerek vagy gyakorlati fogások, melyek - természetesen a kor követelményeihez igazítva - ma is részét képezik a külföldiek ellenőrzésének, míg mások túlhaladottá váltak és eltüntek. A mai idegenrendészeti szakemberek, a Bevándorlási és Állampolgársági Hivatal és a Rendőrség külföldieket ellenőrző állománya számára értékes tapasztalatokat hordozhat e tevékenység történetének és gyökereinek megismerése és a jövőbeli jogszabály-fejlesztések irányainak kijelölésekor is tanácsos figyelembe venni a hagyományos magyar szabályozási elemeket és elveket. Tanulmányom célja elsősorban az idegenrendészet történetének egy szokásostól eltérő szemszögü vizsgálata, melyben a kapcsolódási pontok és összefüggések feltárására koncentráltam. A terjedelmi korlátok nem tették lehetővé egyes részterületek hosszas elemzését, azonban a hivatkozott irodalom, különösen a mellékletként szerepeltetett válogatott jogszabályok jegyzéke alapot adhat további kutatásokhoz. Bár a külföldiekkel kapcsolatos intézkedések ma az uniós joggal harmonizált jogszabályok keretei között történnek, meg kell ôriznünk az önálló fejlődési utat bejárt magyar idegenrendészet értékeit és megemlékezni eredményeiröl. 
Jegyzetek:

${ }^{1}$ WINDT: A menekültügyi szabályozás a nemzetközi és hazai jogban. 111.p. ; TóTH

${ }^{2}$ Külföldi fogalma alatt a tanulmány történelmi korszaktól függetlenül azon személyeket kezeli, akik a hatályos jogszabályok értelmében nem tekinthetők magyar állampolgárnak vagy nem rendelkeztek állampolgársággal (hontalanok). A fogalom jelenlegi terminológia szerinti szétválasztása (szabad mozgás jogával rendelkező személyekre és harmadik országbeliekre) a tárgyalt korszakban nem értelmezhetö, ezért a külföldiekkel kapcsolatos általános és napjainkban is helytálló megállapítások esetében sem kerül alkalmazásra.

3 A külföldiekkel kapcsolatos rendészeti feladatok három nagy csoportba sorolhatók: határrendészeti, idegenrendészeti és menekültügyi szabályok és eszközök alapján. A menekültügyi szabályozás kérdésköre kívül esik e tanulmány keretein.

${ }^{4}$ ÉLIÁs: 1.p.

${ }^{5}$ RÓZSÁs: 291.p.

${ }^{6}$ VIRÁNYI Gergely 2002-es definícióját idézi

WINDT: Külföldiek rendészete, bevándorlás és menekültügy. 298.p.

${ }^{7}$ A tárgyalt korszakban a határrendészet kifejezés nem volt általánosan elterjedt, helyette a határőrizet terminológiát használták. Határőrizet alatt a határforgalom ellenőrzését, a zöldhatár őrzését és a határrend betartatását értették. Így tehát a határőrizet terminus technicus átfogóbb és konkrétabb volt a jelenlegi határrendészet kifejezésnél. A tanulmány a határrendészet kifejezést a mai tartalmának megfelelően használja és — hacsak a jobb megértés miatt nem feltétlenül szükséges - a határörizet kifejezést kerüli.

8 Állami rendőrségek alatt a speciális feladatkörü Magyar Királyi Határrendőrséget, az általános feladatkörü Magyar Királyi Állami Rendőrséget, majd 1931-től a Magyar Királyi Rendőrséget értem.

${ }^{9}$ Például az egyiptomi-núbiai határvidéken a sivatag szélén álló Semna kifejezetten fő migrációs iránynak számított. Az ottani helyőrség írásos jelentései szerint ebben az időben Egyiptom határát stabil (határerődök) és mobil (kb. 50 harci szekérből álló „,különítmények”) erőkkel is őrizték, az államhatárt engedély nélkül átlépőket üldözték, nyomaikat követték, az országba belépni szándékozókat pedig gyakran visszairányították, az ő szavaikkal élve: ,visszaküldték a sivatagba.”

SZÉKELY

${ }^{10}$ DIÓS

${ }^{11}$ SZABÓ Béla: 37-41.p.

${ }^{12}$ GÁSPÁR: 29-41.p. ; BOROSSY: 543-567.p.

${ }^{13}$ HAUTZINGER: A külföldiekre vonatkozó magyar jogi szabályozás fejlödése és története. 10.p.

${ }^{14} 1222 / X I . t c$.

15 1222/XIX.tc.

${ }^{16}$ HAUTZINGER: Az első idegenjogi törvény. 180.p.

${ }^{17}$ Idem: A külföldiekre vonatkozó magyar jogi szabályozás fejlődése és története. op.cit. 18.p.

${ }^{18}$ VÁMBÉRY: 126.p.

${ }^{19}$ HAUTZINGER: Az első idegenjogi törvény. 181.p.

20 1405/II.tc. ; 1405/XVI.tc. ; 1439/V.tc. ; 1453/III.tc. ; 1492/IX.tc. ; 1492/LXXXIV.tc. 1495/XXX.tc. ; 1495/XXXI.tc. ; 1498/XXX.tc. ; 1498/LVI.tc. ; 1525/IV.tc. ; 1563/XXXIV.tc. ; 1600/XXVIII.tc. ; 1601/XXVI.tc. ; 1609/XI.tc. ; 1622/II.tc. ; 1625/XXIV.tc. ; 1647/LXV.tc. ; 1655/XIX.tc.

${ }^{21}$ A Hármaskönyv néven ismeretes az a szokásjogi gyüjtemény, melyet az országbírói ítélőmesterből nádorrá lett WERBÖCZY István állított össze. Eredeti latin címe: ,,Tripartitum opus iuris consuetudinarii inclyti regni Hungariae”, magyarul: „Nemes Magyarország szokásjogának Hármaskönyve”. Lényege: a korabeli Magyarország szokásjogának összegyüjtése, rendszerezése és írásba foglalása.

${ }^{22}$ Az Approbáták (teljes nevén „Approbátae Constitutiones Regni Transilvaniae et Partium Hungariae eidem annexarum”) Erdélynek az 1653. évi gyulafehérvári országgyülés jóváhagyásával kihirdetett törvénykönyve, mely az erdélyi országgyüléseken az 1540. év óta hozott törvénycikkeknek rendszerbe foglalt gyüjteményét tartalmazza.

${ }^{23}$ HAUTZINGER: A külföldiekre vonatkozó magyar jogi szabályozás fejlödése és története. op.cit. 35.p.

${ }^{24} 1715 /$ XCIX.tc.

${ }^{25}$ A közigazgatás és annak részeként a rendvédelem az Osztrák Császárság és a Magyar Királyság belügye volt, amelyben a két társország külön-külön szabadon rendelkezhetett.

GALÁNTAI: 81-162.p.

${ }^{26} 38$ 547/1880. (VIII. 17.) BM.kr. 44. §

${ }^{27}$ SZALAY

${ }^{28}$ 1903/IV.tc. ; 1909/II.tc.

${ }^{29} 1877 /$ XX.tc. $1 . \S$

${ }^{30}$ BENCSIK:13-31.p.

${ }^{31}$ K. NAGY: I. rész. 157-159.p. + II. rész. 169-170.p.

${ }^{32}$ A Kúria 3042-1913. VI. 211. 424. számú határozatát idézi.

ÉLTHES: 269. p.

${ }^{33}$ HAUTZINGER: A külföldiekre vonatkozó magyar jogi szabályozás fejlödése és története. op.cit. 11.p. 
34 „43. § Kerités vétségét követi el, aki valamely tisztességes nöt házasságon kivüli nemi közösülés vagy fajtalanság céljára önérdekböl más részére szándékosan megszerez vagy megszerezni törekszik, ha a nö életének huszadik évét még be nem töltötte.

44. § Kerités vétségét követi el, a ki valamely tisztességes nöt szándékosan reábír, hogy az elöbbi §-ban meghatározott célra bordélyházba vagy hasonló üzletbe lépjen. ...

45. § Tekintet nélkül a sértett nö korára és erkölcsiségére, a kerités büntett, ha a tettes: ...

3. a nöt külföldre szállitja vagy szállittatja;

46. $\S$... A ki a nöt bordélyházban vagy hasonló üzletben elhelyezés végett külföldre szállitja vagy szállittatja, öt évig terjedhetö fegyházzal és ezer koronától ötezer koronáig terjedhetö pénzbüntetéssel ... büntetendö."

1908/XXXVI.tc.

${ }^{35}$ EDVI — DEGRÉ: 439.p.

36 „2. § A büntetőtörvénykönyvek és a bűnvádi perrendtartás kiegészítéséről és módosításáról szóló 1908:XXXVI. törvénycikk (Bn.) negyedik fejezetének XIII. Cikkében foglalt rendelkezések a következőképen módosulnak:

A Bn. negyedik fejezetének XIII. Cikkében a nök részére biztositott büntetöjogi védelem, az egyébként ott megszabott korlátok között a férfinemhez tartozókra is kiterjesztetik. A Bn. 43., 44. és 46. \$-ában emlitett huszadik év a huszonnegyedik évre emeltetik fel."

1925/XIX.tc.

${ }^{37}$ MeZEY: 91.p.

38 1879/L.tc.

${ }^{39}$ Peregriny - Jacobi: 14.p.

${ }^{40}$ WeTZEL: 30.p.

${ }^{41} 1879 /$ L.tc.op.cit. ； 584/1880. (I. 5.) BM.r.

42 1886/IV.tc. ; 1903/V.tc. ; 1921/XXXIII.tc.

${ }^{43} 1871 /$ XVIII.tc.

$441876 /$ V.tc.

45 1879/L.tc. op.cit.

46 1886/XXII.tc.

${ }^{47}$ PeREGRINY — JACOBI: op.cit. 247.p.

${ }^{48} 1886 /$ IV.tc. op.cit.

${ }^{49}$ HAUTZINGER Zoltán: Az első idegenjogi törvény. op.cit. 186.p.

50 1939/XIII.tc.

51 1879/L.tc. op.cit.

${ }^{52}$ PARÁdi - SubA - Vedó: 52.p.

${ }^{53}$ PARÁDI: A polgári Magyarország határőrizeti szervezetének kialakulása, tevékenységének jellemzői, a két világháború közötti magyar határőrizet változásai.

${ }^{54}$ PARÁDI: A magyar rendvédelem története.

${ }^{55}$ A ,szolgálati ág” terminológiát a vizsgált időszakban még nem használták, ezt a kifejezést csupán a közérthetöség érdekében alkalmaztam.

56 SÁNDOR: $522-529$

${ }^{57}$ CSAPÓ: 122-124.p.

${ }^{58}$ PARÁDI: A polgári magyar állam első határőrizeti szakszerve a Magyar Királyi Határrendőrség 1906-1914.

59 1903/IV.tc. ; 1903/V.tc. ; 1903/VIII.tc.

${ }^{60}$ PARÁDI: A csendőrség teendői az Osztrák-Magyar Monarchia Magyar királysága külső határainak őrzésében.

${ }^{61}$ Idem: A Magyar Királyi Csendőrség határőrizeti szolgálata.

${ }^{62}$ Idem: A Magyar Királyi Csendőrség határőrizeti feladatai 1891-1914.

${ }^{63}$ Idem: A dualista Magyarország határörizeti rendszerének kialakulása.

${ }^{64}$ Idem: A dualizmuskori Magyar Királyság határrendőrsége.

${ }^{65}$ A csendörségi SZUT magyarázata. 150.p.

${ }^{66} 1871 /$ XVIII.tc.op.cit.

${ }^{67}, 12$. § Minden honpolgárnak joga van más községbe települni. A települő ezen szándékát azon községnek, a melybe telepedni akar, bejelenti, s a község a települést csak azon esetben tagadhatja meg:

a) ha a települö ellen bebizonyittatik, hogy bünvádi kereset, vagy büntetés alatt van;

b) ha a község terhelése nélkül magát fenntartani nem képes.

14. § Ha a települt azon község kötelékébe, a melybe áttelepedett, fel akar vétetni: a végett az illetö községhez szóval vagy írásban folyamodik; a község a fölvételt azonnal megadhatja.

15. § A települttöl a község kötelékébe felvétel nem tagadtathatik meg:

a) ha a községben 2 évig állandóan lakott;

b) ezen idö alatt ugyanott a községi, ezek nem létében egyéb közterheket folytonosan viselte; és

c) a 12. \$-ban érintett kivételek alá nem esik.

19. § Oly idegenek, kik két év óta állandóan az országban laknak, folytonosan adót fizetnek, és más államnak nem alattvalói, a községek által a községi kötelékbe felvehetök, ha a 12., 14. és 15. §-ok feltételeinek eleget tesznek."

Loc.cit. 
68 „5. § Minden honpolgárnak joga van más községbe települni. A települö ezen szándokát azon községnek, a melybe telepedni akar, bejelenteni s a község a települést csak azon esetben tagadhatja meg:

a) ha a települö ellen bebizonyittatik, hogy bünvádi kereset vagy büntetés alatt van;

b) ha a község terhelése nélkül magát fenntartani nem képes.

7. § Ha a települt azon község kötelékébe, melybe áttelepedett, fel akar vétetni, e végett az illetö községhez a 6. §-ban megállapitott határidön belül is szóval vagy irásban folyamodhatiks a község a felvételt azonnal megadhatja; azt azonban meg nem tagadhatja:

a) ha a települt a községben két évig állandóan lakott;

b) ha ezen idö alatt ugyanott községi adót fizetett vagy ennek nem létében egyéb közterheket folytonosan viselt;

c) ha idöközben az 5. §a) és b) pontjai alatt érintett kivételek alá nem esik.

11. $\S$ Oly idegennek, ki az országban két év óta állandóan lakik, itt folytonosan adót fizet és az 5. és 7. $\S$ feltételeinek eleget tesz, a község a kötelékébe való felvételt magára nézve kötelezöleg kilátásba helyezheti azon feltétel alatt, hogy az idegen igazolni fogja, miként a felvételt más államhoz való alattvalói viszonya nem gátolja. Ezen utóbbi kérdés felett addig, míg a honositási törvény tüzetesen nem intézkedik, a belügyminiszter a fennálló gyakorlat szerint határoz. A belügyminiszter kedvezö határozata után a községi kötelékbe való felvétel azonnal eszközlendö, ellenkezö esetben pedig a felvétel iránt nyújtott kilátás megszüntnek tekintendö."

1876/V.tc.op.cit.

69 „15. $\S$ A külföldi a községben lakhatik, települhet és a község kötelékébe felvétethetik. Ha a községben állandóan lakni akar, tartozik ezt bejelenteni és ha kimutatja, hogy a község terhelése nélkül, magát s családját tartósan fenntartani képes, töle a lakhatási engedély csak erkölcsisége ellen fennforgó alapos gyanú esetében tagadható meg, mód adatván neki a maga igazolására.

A külföldi, ha a községben három hónapig való tartózkodása után az elöljáróság által elörebocsátott felhivás daczára lakási szándékát a felhivásban kitüzendö 8 napi határidö alatt be nem jelenti: a közigazgatási hatóság által 300 frtig terjedhetö pénzbüntetéssel büntetendö kihágást követ el; és ha a felhivás daczára lakási szándékát be nem jelentvén vagy lakási engedélyt nem kapván, távozni nem akar, a távozásra rendöri kényszerrel is szoritható.

Lakási szándék vélelmeztetik, ha a külföldi három hónapon át a községben tartózkodik. Települési engedélyért a honpolgárokra nézve fennálló feltételek mellett folyamodhatik, ha két évi állandó lakását s az alatt erkölcsi jó magaviseletét igazolta.

A községi kötelékbe való felvételt csak a honositás hozzájárultának feltétele mellett szerezheti meg és a község a felvételt neki, ha már az országban öt évig lakott, kilátásba helyezheti, illetve a honositás esetére megadhatja." 1886/XXII.tc. op.cit.

${ }^{70}$ „,69. §... Csavargás vagy koldulás miatt elitéltek büntetésük kiállása után is, ha belföldiek, illetőségük helyére utasithatók, ha pedig külföldiek, az országból kiutasithatók."

1879/XL.tc.

71 9 389/1885. (II. 14.) BM.r.

${ }^{72}$ ÉLTHES: op.cit. 360.p.

73 83 383/1898.BM.elvi.hat.

${ }^{74}$ 1913/XXI.tc.

75 1903/V.tc. op.cit.

${ }^{76} 1878 /$ V.tc.

77 „70. § A ki a magyar állam területéről, vagy annak egyik részéröl, vagy valamely vidék, város vagy község területéröl, a hatóság által jogerejüleg kitiltatott és a tilalom tartama alatt oda, a honnan kitiltatott, a hatóság engedélye nélkül visszamegy: egy hónapig terjedhetö elzárással büntetendö."

1879/XL.tc. op.cit.

${ }^{78}$, „1. § Budapest föváros lakosai, nemkülönben a területén tartózkodó idegenek lak- és tartózkodási helyeinek nyílvántarthatása tekintetéböl, a rendöri bejelentés kötelezettsége a fóváros összes bel- és külterületeire nézve kimondatik. 1879/XXVIII.tc.

${ }^{79}$ Loc.cit.

8054 091/1888. (VIII. 11.) BM.r.

${ }^{81} 100$ 122/1895. (XI. 16.) BM.r.

82117 121/1898. (XII. 9.) BM.r.

83 1903/V.tc. op.cit.

${ }^{84}$ 1993/LXXXVI.tv.

${ }^{85}$ HAUTZINGER: Az első idegenjogi törvény. op.cit.

${ }^{86}$ „44. § Senki sem viselhet más családi és utónevet, mint a melyek születési anyakönyvébe be vannak jegyezve. Ez a rendelkezés az írói vagy müvészi álnevek használatát nem korlátozza. ...

83. § A ki a jelen törvény 44. §-ában foglalt rendelkezést megszegi, kihágást követ el és 200 koronáig terjedhetö pénzbüntetéssel büntetendö."

1894/XXXIII.tc.

${ }^{87}$ 1903/V.tc. 12 . $\S$

${ }^{88}$ „,72. $\S$ A ki szállodákban, vendéglőkben, az idegeneknek nyilvántartására hatóságilag megrendelt vendégkönyvbe vagy jegyzékben, ha a könyv vagy jegyzék átadása mellett arra felhivatott, nevét, állását és lakhelyét be nem irja: ötven forintig terjedhetö pénzbüntetéssel büntetendö. A ki pedig a hatóság tévedésbe ejtése végett nevét, állását vagy lakhelyét hamisan irja be: száz forintig terjedhetö pénzbüntetéssel büntetendö."

1879/XL.tc. op.cit. 
${ }^{89}$ ÉLTHES: op.cit. 279.p.

${ }^{90}$ 1912/LXIII.tc.

${ }^{91}$ SZABÓ

92 1903/V.tc.

9365 000/1909. (IX. 26.) BM.r.

${ }^{94}$ MISKOLCZY- PINCZÉS - CZIRÁKI

95 1903/V.tc. op.cit. 15. §

${ }^{96}$ EDVI - DEGRÉ: op.cit.

${ }^{97}$ A csendör kézikönyve. 41-46.p.

${ }^{98}$ Zsebkönyv a Magyar Királyi Csendőrség számára.. 153-168.p.

${ }^{99} 29$ 601/1886. (XI. 23.) IM.r.

${ }^{100}$ PARÁDI: Határőrizet és kishatárforgalom a dualizmus alatt és a két világháború között.

101 1903/VI.tc.

${ }^{102}$ A Magyar Királyi Csendőrség zsebkönyve. 222-237.

${ }^{103}$ 1903/V.tc. op.cit.

104 1921/XXXIII.tc. op.cit. 56-66 cikk + 247-248 cikk. ； 6500/1921. (IX. 28.) ME.r. ； 69 500/1921 (IX.

30.) BM.kr. ; 84 143/1921. (X. 7.) BM.r.

105 1879/L.tc. op.cit.

106 PEREGRINY - JACOBI: op.cit. 18.p.

${ }^{107} 1886 /$ XXII.tc. op.cit.

${ }^{108}$ A kérvény mintáját a visszahonosítási kérelmek tárgyalásának egyszerűsítéséről és gyorsításáról szóló BM rendelet tartalmazta.

12 551/1926. (III. 15.) BM.r. 2.sz.melléklet.

${ }^{109} 1879 /$ L.tc. op.cit.

1103 240/1920. (IV. 19) ME.r.

${ }^{111}$ Az OMH élén 6-10 fös Országos Menekültügyi Tanács állt, amely elsősorban véleményező jogkörrel bírt.

PETRICHEVICH-HORVÁTH

112 8352/1920. (X. 27.) ME.r.

$113684 / 1921$. (II. 1.) ME.r.

114 2344/1924. (III. 28.) ME.r.

115200 000/1925. (IV. 25.) BM.r.

${ }^{116}$ DEÁK: 684-686.p.

117 1903/V.tc. op.cit.

118200 000/1925. (IV. 25.) BM.r. op.cit.

${ }^{119}$ A részletszabályokat a külföldieknek az ország területén lakhatásáról szóló 1903/V.tc. végrehajtására kibocsátott 200.000/1925. BM rendelet és a külföldiek tartózkodási engedélyéröl szóló 101 000/1927. BM rendelet tartalmazták.

200 000/1925. (IV. 25.) BM.r. op.cit. ； 101 000/1927. (I. 6.) BM.r. ; Szerkesztőségi közlemények.

1205 047/1919. (X. 1.) ME.r.

121 7270/1930. (XI. 20.) ME.r.

122 1931. III. 1-én bejelentőhivatalok müködtek:

- A Budapesti rendőr-fökapitányság területén: Budapest, Újpest, Kispest, Pesterzsébet, Pestszentlőrinc, Pestújhely, Csepel, Rákospalota, Gödöllő;

- A Budapestvidéki ker. fókapitányság területén: Vác, Szentendre, Salgótarján, Szolnok, Esztergom, Cinkota,

Rákosszentmihály, Sashalom, Budafok, Albertfalva, Budatétény, Nagytétény, Eger, Jászberény, Balassagyarmat, Hatvan, Gyöngyös;

- A Debreceni ker. főkap. területén: Debrecen, Miskolc, Sátoraljaújhely, Nyíregyháza, Hajdúböszörmény, Hajdúnánás;

- A Szegedi ker. fökap. területén: Szeged, Kecskemét, Békéscsaba, Kiskunhalas, Hódmezővásárhely, Csongrád, Orosháza, Gyula, Kiskunfélegyháza, Makó, Szentes, Nagykőrös;

- A Székesfehérvári ker. főkap. területén: Székesfehérvár, Kaposvár, Pécs, Baja, Veszprém, Szekszárd, Mohács, Tatabánya, Komárom;

- A Szombathelyi ker. főkap. területén: Győr, Nagykanizsa, Sopron, Szombathely, Magyaróvár, Zalaegerszeg, Pápa, Köszeg.

63 410/1930. (XII. 16.) BM.r.

$1231881 /$ XXI.tc.

${ }^{124}$ ÉLTHES: op.cit. 276-280.p.

125 1903/V.tc. op.cit.

126 1930/XXVIII.tc.

127100 000/1930. (XI. 6.) BM.r.

${ }^{128}$ KovÁCs-BunA: Külföldiek munkavállalásának ellenőrzése. 305-309.p.

129 1930/XXVIII.tc. op.cit. ; 1903/V.tc. op.cit.

130 1903/V.tc. op.cit.

131 1930/XXVIII.tc. op.cit.

132100 000/1930. (XI. 6.) BM.r. op.cit.

${ }^{133}$ Loc.cit. 19. §

1344 352/1920. (III. 27.) BM.int. 
135 ÉLTHES: op.cit. 289.p.

136 „6. \$A minisztérium az 1912:LXIII., az 1912:LXVIII. és az 1912:LXIX. törvénycikkben, valamint a háborúval kapcsolatos más törvényekben foglalt rendelkezéseknek és az e törvények alapján akár a minisztérium, akár egyes miniszterek által kiadott rendeleteknek, vagy e törvények és rendeletek alapján tett hatósági rendelkezéseknek megszegését kihágássá nyilvánithatja s az ily kihágás büntetését hat hónapig terjedhetö elzárásban és kétezer koronáig terjedhetö pénzbüntetésben állapithatja meg; továbbá oly esetben, amikor megállapitható annak a nyereségnek mennyisége, amelyet a tettes cselekményével illetéktelenül elért, az alkalmazandó pénzbüntetés legmagasabb mértékéül a minisztérium a kihágást megállapitó jogszabályban meghatározott pénzbüntetésnek a megállapitott nyereség kétszeresével felemelt összegét állapithatja meg."

1916/IV.tc.

${ }^{137}$ 1903/V.tc. op.cit.

138 1920/XXV.tc.

$1391921 /$ III.tc.

140 „9. $\S$ Az 1., 2. és 5-8. §-okban meghatározott büncselekmények esetében a hivatalvesztést és a politikai jogok gyakorlatának felfüggesztését is meg kell állapitani, külföldit az országból ki kell utasítani és a visszatéréstöl örökre el kell tiltani; belföldit pedig abból a községböl, ahol tartózkodása az állam és a társadalom törvényes rendje szempontjából veszedelmes, akkor is ki lehet tiltani, ha az elitéltnek illetöségi helye." Loc.cit.

141 1915/XIX.tc.

142 1922/XXVI.tc

143129 405/1908. (X. 15.) BM.kr.

${ }^{144}$ KeLEMEN: 6-10.p.

${ }^{145}$ KovÁCS-BunA: Világutazók. 166-172.p.

146 MiLvius

${ }^{147}$ A csendörségi SZUT magyarázata. op.cit.

${ }^{148}$ KovÁCS-BunA: Világutazók. 166-172.p. op.cit.

149 DEÁK: op.cit. 684-686.P.

15086 225/1895. (X. 29.) BM.r.

${ }^{151}$ A csendörségi SZUT magyarázata. op.cit. 134.p.

15281 000/1924. (V. 20.) BM.kr.

${ }^{153} 1913 /$ XXI.tc. op.cit. 1. §

${ }^{154}$ Szerkesztőségi közlemények.

${ }^{155}$ KovÁCS-BuNA: Külföldiek munkavállalásának ellenőrzése. op.cit.

156 NÉMETHY

15750 431/1891. (VII. 15.) BM.r.

${ }^{158}$ PARÁDI: Csendőrség a határörizetben. 64.p.

15948 999/1912. (IV. 13.) BM.r. ; 58 320/1912. (IV. 13.) BM.r.

16057 000/1909. (VI. 15.) BM.kr.

${ }^{161}$ PARÁDI: Az Osztrák-Magyar Monarchia Magyar Királyságának határszéli csendőrsége.

${ }^{162}$ PARÁDI: A magyar határőrizet tere a kiegyezéstől a második világháborúig.

${ }^{163}$ SZUT-1881. 18. § ; 35. $; ; 54 . \S ; 55 . \S$

${ }^{164}$ SZUT-1900. 153. §.

${ }^{165}$ SZUT-1912. Határszéli szolgálat. 153. §. III. rész Határszéli szolgálati utasítás $4 . \S ； 6 . \S ； 11$ § ；13. § ; 14. $\S ; 16 . \S$

166 1903/V.tc.op.cit. ; 90 000/1905. (IV. 13.) BM.kr.

16729 807/1906. (VI. 16.) BM.kr.

16834 283/1906. (V. 4.) BM.kr.

16971 000/1904. (VII. 18.) BM.r. ; 71 500/1904. (VII. 26.) BM.r.

${ }^{170}$ SZUT-1924. 45. § 250. pont ; 253. pont.

${ }^{171}$ SZUT-1927. 59. §. 376. ; 377. ; 378. pontok.

172 SZUT-1941. 59. §.

${ }^{173}$ PARÁDI: A dualista Magyarország határôrizeti rendszerének kialakulása. op.cit.

${ }^{174}$ PARÁDI: A Magyar Királyi Határrendőrség. 139-159.p.

175 1903/VIII.tc. op.cit.

17691 000/1905. (XII. 29.) BM.r.

177 PARÁDI: Rendörség a határörizetben. 56.p.

178 5645/1923. (VI. 4.) BM.r.

${ }^{179}$ PARÁDI: Áttérés a háborús határőrizetre az első világháború előtt.

${ }^{180}$ PARÁDI: A magyar állam határőrizete a kiegyezéstől a II. vh-ig.

${ }^{181}$ PARÁDI: Rendörség a határörizetben.

182 PARÁDI: A Magyar Királyi Határrendőrség, a magyar határőrizet szakmai vezető testülete.

18354 975/1908. (IV. 30.) BM.r. ; 58 320/1912. (IV. 13.) BM.r.

${ }^{184}$ PARÁDI: A dualizmuskori magyar rendvédelem és határőrizet. A Magyar Királyi Határrendőrség. 5-46.p.

${ }^{185}$ PARÁDI: A határszéli csendőrség állambiztonsági feladatai.

${ }^{186}$ PARÁDI: A Magyar Királyság határrendőrsége.

${ }^{187}$ LAKY — PAVLIK 


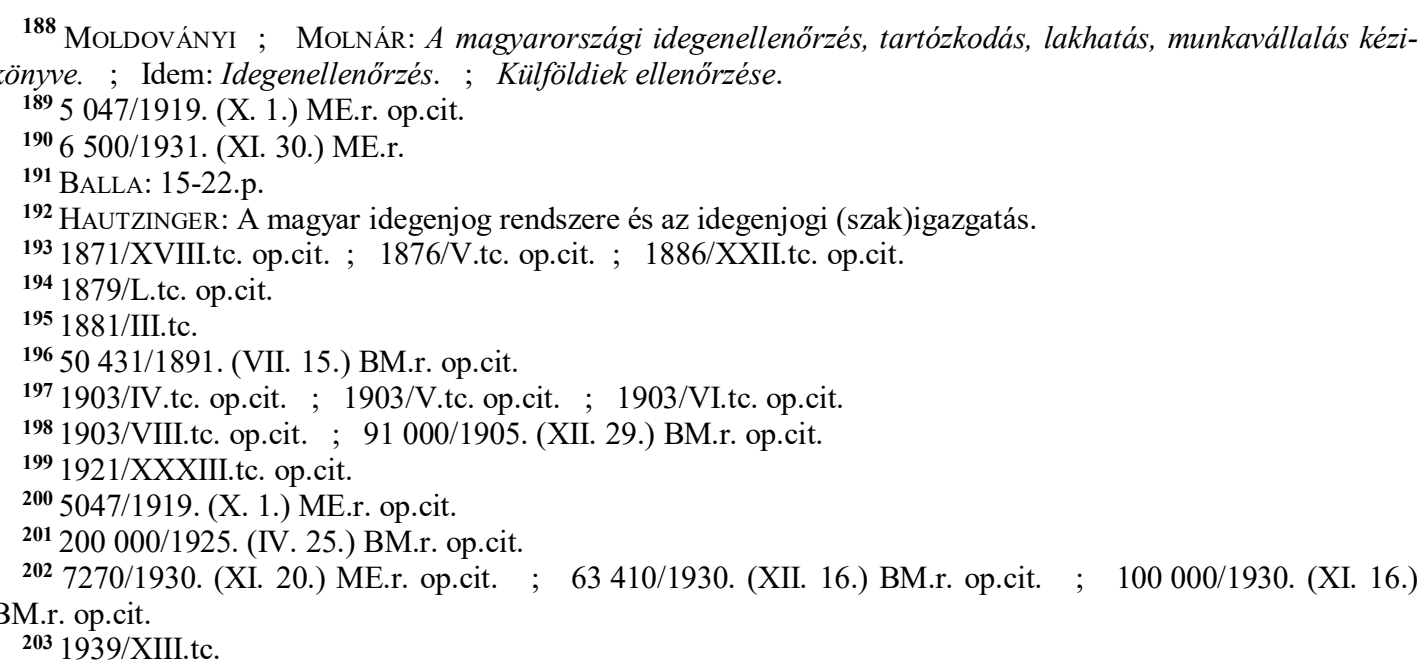

Jegyzetekben alkalmazott röviditések:

\section{MONOGRÁFIÁK, KISMONOGRÁFIÁK ÉS HASONLÓ JELLEGŰ KÖTETEK}

CSAPÓ

ÉLTHES

(32., 72., 89., 124., 135.,)

GALÁNTAI

(25.,)

HAUTZINGER: A külföldiekre vonatkozó magyar jogi szabályozás fejlödése és története. (13., 17., 23., 33.,)

LAKY - PAVLIK

(187.,)

MOLDOVÁNYI

(188.,)

MolnÁR: A magyarországi idegenellenörzés, tartózkodás, lakhatás, munkavállalás kézikönyve.

(188.,)

MOLNÁR: Idegenellenörzés.

(188.,)

NÉMETHY

(156.;)

PARÁDI: A magyar rendvédelem története.

(54.,)

PARÁDI: Csendörség a határôrizetben.

(158.,)
CSAPÓ Csaba: A Magyar Királyi Csendőrség története 1881-1914. Pécs, 1999, Pro Pannónia Kiadói Alapítvány. 186 p. HU-ISBN 963 907940 5. /Pannónia Könyvek./ HU-ISSN 0237-4277.

- ÉLThes Gyula: A kihágások és felsőbírósági határozatok. I.köt. Budapest, 1931, Stádium Sajtóvállalat Rt. 528.p.

- Galántai József: A Habsburg-monarchia alkonya. Osztrák-magyar dualizmus 1867-1918. Budapest, 1985, Kossuth. 386 p. HU-ISBN 9630925893.

- HAUTZINGER Zoltán: A külföldiekre vonatkozó magyar jogi szabályozás fejlödése és története. Budapest, 2012, Nemzeti Közszolgálati Egyetem. 75 p. HU- ISBN 9789630832711.

- LAKy Imre - PavliK Ferenc: Határrendészet kézikönyve. Határrendörség, bevándorlás, kivándorlás, útlevél s ezzel összefüggö törvények és rendeletek gyüjteménye. Budapest, 1907, Pátria Irodalmi Vállalat és Nyomdai Rt. 404 p.

- MoldovÁNYI László: Tájékoztató a külföldiek részére szükséges tartózkodási, munkavállalási, lakhatási és beköltözési engedélyek megszerzéséröl és a visszahonositási eljárásról. Szeged, 1929 Városi Nyomda. $15 \mathrm{p}$.

- MolnÁR Mihály: A magyarországi idegenellenőrzés, tartózkodás, lakhatás, munkavállalás kézikönyve. Budapest, 1931. Könyves Kálmán Kiadó. 88 p.

- MoLnÁR Mihály: Idegenellenőrzés. Budapest, 1935. Király Elemér kiadása. $84 \mathrm{p}$.

- NÉmeTHY Ferenc: A Magyar Királyi Csendörség szervezete, szolgálata és viszonya a közigazgatási hatóságokhoz. I. köt. A Magyar Királyi Csendörség hatásköre, jogai, szolgálati teendöi és eljárása. II-III.köt. A Magyar Királyi Csendörség viszonya a közigazgatási hatóságokhoz. Budapest, 1900, Országos Központi Községi Nyomda Részvénytársaság. 72 p. és 162 p. /Közigazgatási Könyvtár./

PARÁDI József et al. (szerk.): A magyar rendvédelem története. Budapest, 1995, Tipico Design. 317 p. HU-ISBN 963046215 X.

PARÁDI József: Csendőrség a határőrizetben. Budapest, 2003, Tipico Design. 186 p. HU-ISBN 963762331 0. /Rendvédelem a határokon a XIX-XX. században, 2./ HU-ISSN - 
PARÁDI: Rendőrség a határőrizetben.

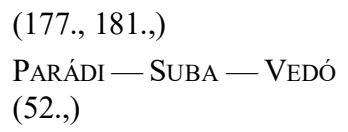

\section{TANULMÁNYOK}

BALLA

(191.;

BENCSIK

(30.;)

BOROSSY

(12.,)

ÉLIÁS

(4.,)

HAUTZINGER Zoltán: Az első idegenjogi törvény. (16., 19., 49., 85.,)

HAUTZINGER Zoltán: A magyar idegenjog rendszere és az idegenjogi (szak)igazgatás.

(192.,)

PARÁDI: A dualista Magyarország határörizeti rendszerének kialakulása.

$$
\text { (83., 173.,) }
$$

PARÁDI: A polgári magyar állam első határőrizeti szakszerve a Magyar Királyi Határrendőrség 1906-1914. (58.,)

PARÁDI: A Magyar Királyi Csendörség határőrizeti feladatai 18911914.

(62.,)
PARÁDI József: Rendörség a határörizetben. Budapest, 2003, Tipico Design. 266 p. HU-ISBN 963762332 9. /Rendvédelem a határokon a XIX-XX. században, 3./ HU-ISSN -

- PARÁdi József — SuBA János — Vedó Attila: A magyar-román határ és örzése 1881-1918. Budapest, 2011, Szemere Bertalan Magyar Rendvédelem-történeti Tudományos Társaság. 138 p. HU-ISBN 978963081708 0. /A magyar rendvédelem-történet öröksége, 1./ HU-ISSN 2062-8447. 52.p.

- Peregriny Géza - JACOBI Roland: Magyar állampolgárság, községi illetőség és idegenrendészet. I. köt. Budapest, 1930, Phönix. $336 \mathrm{p}$.

- Tóth Judit: Státusjogok. Budapest, 2004, Lucidus Kiadó. 328 p. HU-ISBN 963946526 7. /Kisebbségkutatás Könyvek./ HU-ISSN 1585-3144

- VÁMBÉRY Ármin: A magyarság keletkezése és gyarapodása. Budapest, 1895, Franklin. 408 p.

Wetzel Tamás: A bevándorlás kérdése Magyarországon. Budapest-Pécs, 2011, Publikon Kiadó - IDResearch Kft. 193 p. HU-ISBN 9786155001390 .

- BaLla Zoltán: Közigazgatás és rendészet. Új magyar közigazgatás, VI.évf. (2013) 12.sz. 15-22.p. HU-ISSN 2060-4599

BENCSIK Péter: A kivándorlás jogi szabályozása 1903-1914. Rendvédelem-történeti Füzetek (Acta Historiae Praesidii Ordinis), XII.évf. (2007) 15.sz. 13-31.p. HU-ISSN 1216-6774. A tanulmány korábbi változata 2001. november 6-án, Budapesten hangzott el a Szemere Bertalan Magyar Rendvédelem-történeti Tudományos Társaság által szervezett rendvédelem-történeti tudományos konferencia-sorozatnak ,Az európai és a magyar rendvédelem a XIX-XX. században." címü XV. konferenciáján. A publikált tanulmány az előadás javított, bővített és átdolgozott változata.

- Borossy András: Határőrség és határörök az Árpád-korban. Hadtörténelmi Közlemények, XC.évf. (1977) 4.sz. 543-567.p. HU-ISSN 0017-6540

- ÉLIÁS Pál: A külföldiek jogi helyzetével kapcsolatos alapvető kérdések. 39-49.p. In KONRÁD Judit (szerk.): Idegenjog. I. köt. Budapest, 1987, MTA Államtudományi Kutatások Programirodája. 255 p. HU-ISSN $0231-4800$.

HAUTZINGER Zoltán: Az első idegenjogi törvény. 179-191.p. In GAÁL Gyula - HAUTZINGER Zoltán (szerk.): A modern magyar határrendészet száztíz éve. Budapest, 2013, Magyar Rendészet-tudományi Társaság Határrendészeti Tagozat. 298 p. HU-ISBN 978963 0862127.

- HAutzinger Zoltán: A magyar idegenjog rendszere és az idegenjogi (szak)igazgatás. Pro Publico Bono - Magyar Közigazgatás, II.évf. (2014) 2.sz. 69-78.p. HU-ISSN 0865-736X.

PARÁDI József: A dualista Magyarország határőrizeti rendszerének kialakulása. Belügyi Szemle, XXX.évf. (1982) 10.sz. 44-51.p. HUISSN 0133-6738.

PARÁDI József: A polgári magyar állam első határőrizeti szakszerve a Magyar Királyi Határrendőrség 1906-1914. Hadtörténelmi Közlemények, CI.évf. (1986) 3.sz. 541-570. p. HU-ISSN 0017-6540.

PARÁDI József: A Magyar Királyi Csendőrség határőrizeti feladatai 1891-1914. Hadtörténelmi Közlemények, CIII.évf. (1988) 1.sz. 5692.p. HU-ISSN 0017-6540. 
PARÁDI József: A Magyar Királyi Határrendőrség, a magyar határörizet szakmai vezető testülete. (182.,)

PARÁDI: Áttérés a háborús határörizetre az első világháború előtt. (179.,)

PARÁDI: A polgári Magyarország határörizeti szervezetének kialakulása, tevékenységének jellemzői, a két világháború közötti magyar határőrizet változásai.

(53.,)

PARÁDI: Határőrizet és kishatárforgalom a dualizmus alatt és a két világháború között.

(100.,)

PARÁDI: A magyar állam határőrizete a kiegyezéstől a II. vh-ig. (180.,)

PARÁDI: A határszéli csendőrség állambiztonsági feladatai. (185.,)

PARÁDI: A dualizmuskori magyar rendvédelem és határörizet. A Magyar Királyi Határrendőrség. (184.,)
PARÁDI József: A Magyar Királyi Határrendőrség, a magyar határörizet szakmai vezető testülete. Rendvédelem-történeti Füzetek (Acta Historiae Praesidii Ordinis), III.évf. (1993) 4.sz. 21-50.p. HUISSN 1216-6774. A tanulmány korábbi változata 1992. szeptember 29-én Budapesten hangzott el a Szemere Bertalan Magyar Rendvédelem-történeti Tudományos Társaság által szervezett rendvédelem-történeti tudományos konferenciasorozatnak „A dualista Magyarország rendvédelme" címủ IV. konferenciáján. A publikált tanulmány az előadás javított, bővített és átdolgozott változata.

PARÁDI József: Áttérés a háborús határőrizetre az első világháború elött. Rendvédelem-történeti Füzetek (Acta Historiae Praesidii Ordinis), IV.évf. (1994) 5.sz. 13-17.p. HU-ISSN 1216-6774. A tanulmány korábbi változata 1993. szeptember 21-én Budapesten hangzott el a Szemere Bertalan Magyar Rendvédelem-történeti Tudományos Társaság által szervezett rendvédelem-történeti tudományos konferenciasorozatnak a „Háború, forradalom, trianon” címü V. konferenciáján. A publikált tanulmány az előadás javított, bővített és átdolgozott változata. 13-17.p.

PARÁDI József: A polgári Magyarország határőrizeti szervezetének kialakulása, tevékenységének jellemzői, a két világháború közötti magyar határörizet változásai. Határőrségi Tudományos Közlemények, IV.évf. (1994) 1.sz. 4-23.p. HU-ISSN -

PARÁDI József: Határőrizet és kishatárforgalom a dualizmus alatt és a két világháború között. Rendvédelem-történeti Füzetek (Acta Historiae Praesidii Ordinis), X.évf. (2000) 11.sz. 42-53.p. HU-ISSN 1216-6774. A tanulmány korábbi változata 1999. április 20-án Budapesten hangzott el a Szemere Bertalan Magyar Rendvédelem-történeti Tudományos Társaság által szervezett rendvédelem-történeti tudományos konferenciasorozatnak a „Szabad mozgás a Kárpát-medencében” címü XI. konferenciáján. A publikált tanulmány az előadás javított, bővített és átdolgozott változata.

PARÁDI József: A magyar állam határőrizete a kiegyezéstől a II. vh-ig. 74-109.p. In BoDA József (szerk.): A magyar polgári rendvédelem a XIX-XX. században. A magyar büntetés-végrehajtás, csendörség, határörség, koronaörség, rendörség, vám- és pénzügyörség. Budapest, 2004, Belügyminisztérium Nemzetközi Oktatási Központ - Szemere Bertalan Magyar Rendvédelem-történeti Alapítvány. 2015 p. A tanulmány korábbi változata 2003. nyarán Budapesten hangzott el a Szemere Bertalan Magyar Rendvédelem-történeti Alapítvány által szervezett magyar rendvédelem-történeti témájú nyári szabadegyetemen. A publikált tanulmány az előadás javított, bővített és átdolgozott változata. HU-ISBN -

PARÁDI József: A határszéli csendőrség állambiztonsági feladatai. Rendvédelem-történeti Füzetek (Acta Historiae Praesidii Ordinis), XI.évf. (2005) 14.sz. 91-94.p. HU-ISSN 1216-6774. A tanulmány korábbi változata - német nyelven - 2002 februárjában Budapesten hangzott el a Szemere Bertalan Magyar Rendvédelem-történeti Tudományos Társaság Csendőrség-történeti Szakosztálya által szervezett tudományos rendezvénysorozat „A csendörség Magyarországon" című II. szimpozionján. A publikált tanulmány az előadás javított bővített és átdolgozott változata.

PARÁDI József: A dualizmuskori magyar rendvédelem és határőrizet. A Magyar Királyi Határrendőrség. Határrendészeti Tanulmányok, III.évf. (2006) 1.sz. 5-46.p. HU-ISSN 1786-2345. A tanulmány korábbi változata 2006. január 17-én Budapesten hangzott el a Szemere Bertalan Magyar Rendvédelem-történeti Tudományos Társaság és a Határörség Országos Parancsnoksága közös szervezésében megvalósított konferencián. „Az ezeréves magyar rendvédelem” címü XIV. konferenciáján. A publikált tanulmány az előadás javított, bővített és átdolgozott változata. 
PARÁDI: A magyar határőrizet tere a kiegyezéstől a második világháborúig. $(162 .$,

PARÁdI: A Magyar Királyi Határrendőrség. (174.,)

PARÁDI: A Magyar Királyság határrendörsége.

(186.,)

PARÁDI: A Magyar Királyi Csendörség határőrizeti szolgálata. $(61 .$,

PARÁDI: A csendőrség teendői az Osztrák-Magyar Monarchia Magyar királysága külső határainak örzésében.

(60.,)

PARÁDI József: Az Osztrák-Magyar Monarchia Magyar Királyságának határszéli csendőrsége.

(161.;)

PARÁDI: A dualizmuskori Magyar Királyság határrendőrsége. (64.)

RózSÁs

(5.)
PARÁDI József: A magyar határőrizet tere a kiegyezéstől a második világháborúig. Rendvédelem-történeti Füzetek (Acta Historiae Praesidii Ordinis), XII.évf. (2007) 15.sz. 125-138.p. HU-ISSN 12166774. A tanulmány korábbi változata 2005 . augusztus 27 -én a szlovéniai Lendván hangzott el a Hajnal István kör által szervezett tudományos konferencián. A publikált tanulmány az előadás javított, bővített és átdolgozott változata.

PARÁDI József: A Magyar Királyi Határrendőrség. Rendvédelemtörténeti Füzetek (Acta Historiae Praesidii Ordinis), XII. évf. (2007) 15.sz. 139-159.p. HU-ISSN 1216-6774. A tanulmány korábbi változata 2004. áprilisában Budapesten hangzott el a Szemere Bertalan Magyar Rendvédelem-történeti Tudományos Társaság Rendőrségtörténeti Szakosztálya által szervezett Szemere Beszélgetések szimpózionsorozat rendezvényén a Rendőrség Tudományos Tanácsának közreműködésével. A publikált tanulmány az előadás javított, bővített és átdolgozott változata.

PARÁDI József: A Magyar Királyság határrendőrsége. Rendvédelem-történeti Füzetek (Acta Historiae Praesidii Ordinis), XVIII. évf. (2010) 21. sz. 101-116.p. HU-ISSN 1216-6774. A tanulmány korábbi változata 2007. október 5.-én Budapesten hangzott el a Szemere Bertalan Magyar Rendvédelem-történeti Tudományos Társaság által szervezett rendvédelem-történeti tudományos konferencia-sorozatnak „A magyar rendvédelem fejlödése a XIX-XX. században” címü XXI. konferenciáján. A publikált tanulmány az előadás javított, bővített és átdolgozott változata. 106.p. 20.sz.jegyzet.

PARÁDI József: A Magyar Királyi Csendőrség határőrizeti szolgálata. Rendvédelem-történeti Füzetek (Acta Historiae Preasidii Ordinis), XIX. évf. (2010) 22. sz. 77-91.p. A tanulmány korábbi változata 2008. október 10.-én Budapesten hangzott el, a Szemere Bertalan Magyar Rendvédelem-történeti Tudományos Társaság által szervezett rendvédelem-történeti tudományos konferenciasorozatnak „Másfél évszázad rendszerváltozásainak hatásai a nemzeti rendvédelmünkre" címü XXII. konferenciáján. A publikált tanulmány az előadás javított, bővített és átdolgozott változata.

PARÁDI József: A csendőrség teendői az Osztrák-Magyar Monarchia Magyar Királysága külső határainak őrzésében. Rendvédelemtörténeti Füzetek (Acta Historiae Praesidii Ordinis), XXI.évf. (2011) 24.sz. 100-118.p. HU-ISSN 1216-6774. A tanulmány korábbi változata 2009.december 3-án, Budapesten hangzott el, a Szemere Bertalan Magyar Rendvédelem-történeti Tudományos Társaság által szervezett rendvédelem-történeti tudományos konferenciasorozatnak „Csendörség Ausztria-Magyarországon, illetve Ausztriában és Magyarországon 1849-2005” címü XXIV. konferenciáján. A publikált tanulmány az előadás javított, bővített és átdolgozott változata.

PARÁDI József: Az Osztrák-Magyar Monarchia Magyar Királyságának határszéli csendőrsége. Rendvédelem-történeti Füzetek (Acta Historiae Praesidii Ordinis), XXII.évf. (2012) 26.sz. 81-104.p. HUISSN 1216-6774. A tanulmány korábbi változata 2011.november 11.-én, Budapesten hangzott el, a Szemere Bertalan Magyar Rendvédelem-történeti Tudományos Társaság által szervezett rendvédelemtörténeti tudományos konferenciasorozatnak ,,Militarizmus és demilitarizmus a XIX-XX. századi magyar állam rendvédelmében" címü XXV. konferenciáján. A publikált tanulmány az előadás javított, bővített és átdolgozott változata.

PARÁDI József: A dualizmuskori Magyar Királyság határrendőrsége. 45-59.p. In GAÁL Gyula - HAUTZINGER Zoltán (szerk.): A modern magyar határrendészet száztíz éve. Budapest, 2013, Magyar Rendészet-tudományi Társaság Határrendészeti Tagozat. 298 p. HUISBN 9789630862127.

RÓzSÁs Eszter: Az idegenrendészet 291-301.p. In CHRONOWSKI Nóra - Petrétei József (szerk.): Tanulmányok Ádám Antal professor emeritus születésének 80. évfordulójára. Pécs, 2010, PTEÁJK.559 p. HU-ISBN 9789636423148. 
WINDT: A menekültügyi szabályozás a nemzetközi és hazai jogban. (1.;)

WINDT: Külföldiek rendészete, bevándorlás és menekültügy. (6.;)

\section{CIKKEK}

DEÁK

(116., 149.,)

K. NAGY

(31.,)

\section{KELEMEN}

(144.,)

KovÁCs-BunA: Világutazók.

(145.,)

KovÁCs-BunA: Külföldiek munkavállalásának ellenőrzése. (128., 155.,)

Milvius

(146.,)

SÁNDOR

(56.;)

SzABó Béla

(11.;)

SZABÓ Jenő

(91.;)

SZALAY

(27.;)

Szerkesztőségi közlemények.

(119.;)

Szerkesztőségi közlemények. Csendőr lexikon.

(154.;)

\section{LEXIKONOK}

Diós

(10.;)

\section{KÉZIRATOK}

SZÉKELY

\section{TANKÖNYVEK}

GÁSPÁR

(12.;)

MeZEY

(37., )

MISKOLCZY- PINCZÉS - CZIRÁKI (94.;)

A csendőrségi Szolgálati Utasitás magyarázata. (65., 147.;)
WiNDT Szandra: A menekültügyi szabályozás a nemzetközi és hazai jogban. Rendészeti szemle, LVIII.évf. (2010) 2.sz. 104-126.p. HU-ISSN 1218-8956.

WINDT Szandra: Külföldiek rendészete, bevándorlás és menekültügy. 291-307.p. In KORINEK László (szerk.): Értekezések a rendészetröl. Budapest, 2014, NKE-RTK. 360 p. HU-ISBN 97861553 05917.

- DEÁK Andor: Külföldiek ellenörzése és a nyilván nem tartott külföldiek kinyomozása a csendőrség által. Csendőrségi Lapok, XVIII.évf. (1928) 25.sz. 684-686.p.

- K. NAGY Sándor: A kivándorlás és a csendőr.

- I. rész.Csendörségi Lapok, III.évf. (1909) 14.sz. 157-159.p.

- II. rész. Csendőrségi Lapok, III.évf. (1909) 15.sz. 169-170.p.

- Kelemen Miklós: Idegenrendészet a községekben. Csendörségi Lapok, XIV.évf. (1924) 6.sz. 6-10.p.

- KovÁcs-Buna Károly: Világutazók. Csendörségi Lapok, XXIII.évf. (1933) 6.sz. 166-172.p.

- KovÁcs-Buna Károly: Külföldiek munkavállalásának ellenőrzése. Csendörségi Lapok, XXV.évf. (1935) 10.sz.305-309.p.

- Milvius Attila: Idegenforgalom és csendőrség. Csendőrségi Lapok, XXI.évf. (1931) 13.sz. 351-352.p.

- SÁNDOR László: A csendőrség szolgálata Nagymagyarország határain. Csendőrségi Lapok, XIX.évf. (1929) 18.sz.. 522-529.p.

- SzABÓ Béla: Civis Romanus. A római társadalom jogi kategóriái. Rubicon, VIII.évf. (1997) 3-4.sz. 37-41.p. HU-ISSN 0865-6347.

- SzABÓ Jenő: Idegenek ellenőrzése. Csendőrségi Lapok, XIV.évf. (1924) 1.sz. 2-3.p.

- $\quad$ SZALAY Szabolcs: Idegenek a községben. Csendörségi Lapok, XVIII.évf. (1928) 32.sz. 891-893.p.

- Szerkesztőségi közlemények. Csendőr lexikon. Csendőrségi Lapok, XVIII.évf. (1928) 36.sz. 1019.p.

- Szerkesztőségi közlemények. Csendőr lexikon. Csendörségi Lapok, XXI.évf. (1931) 18.sz. 489.p.

- Diós István (szerk.): Magyar katolikus lexikon. (Homo-J). V.Köt. Budapest, 2000, Szent István Társulat. 975 p. HU-ISBN 9633611237.

- SzÉKely Zoltán: Rendvédelem és rendvédelmi jog fejlödése az Európai Unió tagállamai területén. (Ph.D. disszertáció tervezet) Pécs, 2014, PTE Ảllam- és Jogtudományi Karának Doktori Iskolája. $132 \mathrm{p}$.

- GÁsPÁR László: A határörzés története. I.köt. Budapest, 1988, Zrínyi Miklós Katonai Akadémia. (tansegédlet) 133 p. HU-ISBN -

- Mezey Barna et al. (szerk.): Magyar jogtörténet. Budapest, 20074, Orisis. 515 p. HU-ISBN 978963389901 4. /Osiris tankönyvek./ HU-ISSN 1218-9855.

- MiskolCZY Ágost - PINCZÉs Zoltán - CZIRÁKI Ferenc: A magyar büntetőjog gyakorlati kézikönyve a Magyar Királyi Csendörség számára. II. kötet, Budapest, 1937, Stádium.1844 p.

- A csendőrségi Szolgálati Utasitás magyarázata. Máramarossziget, 1909, Kaufman Á. És Fiai. 175 p. 


\section{JOGSZABÁLYMAGYARÁZATOK}

EDVI-DEGRÉ

(35., 96.;)

Külföldiek ellenörzése.

(188.;)

\section{ZSEBKÖNYVEK}

Zsebkönyv a Magyar Királyi

Csendörség számára.

(98.;)

A csendör kézikönyve.

(97.;)

A Magyar Királyi Csendörség zsebkönyve.

(102.;)

\section{JELENTÉSEK}

PETRICHEVICH-HoRvÁTH

(111.;)

\section{SZABÁLYZATOK}

SZUT-1881.

(163.;)

SZUT-1900.

(164.;)

SZUT-1912.

(165.;)

SZUT-1924.

(170.;)

SZUT-1927.

(171.;)

SZUT-1941.

(172.;)

\section{JOGSZABÁLYOK}

1222/XI.tc.

(14.;)

1222/XIX.tc.

(15.;)

1405/II.tc.

(20.;)

1405/XVI.tc.

(20.;)

1439/V.tc.

(20.;)

1453/III.tc.

(20.;)

1492/IX.tc.

1492/LXXXIV.tc.

(20.;)

1495/XXX.tc.

1495/XXXI.tc.

1498/XXX.tc.

(20.;)
EDVI Illés Károly — DEGRÉ Miklós: A Magyar büntetőtörvények zsebkönyve. Budapest, $1929^{9}$, Révai. 813 p.

Külföldiek ellenőrzése. Szombathely, 1938, Martineum. 244.p.

- Zsebkönyv a Magyar Királyi Csendörség számára. (IV. évfolyam) Budapest, 1890, Franklin. 271 p.

- A csendör kézikönyve. Utasitás a tábori csendörség részére kérdésekben és feleletekben. Szeged, 1894, Várnay. 62 p.

- A Magyar Királyi Csendörség zsebkönyve. (XX. évfolyam) Budapest, 1906, Franklin. 367 p.

- Petrichevich-Horváth Emil: Jelentés az Országos Menekültügyi Hivatal négy évi müködéséröl. Budapest, 1924. Pesti Könyvnyomda. 44 p.

- Utasitás a Magyar Királyi Csendörség számára. Budapest, 1881, Pesti Könyvnyomda. 191 p.

[az utasítás megjelent még: Magyarországi Rendeletek Tára, XV.évf. (1881) 4.sz. 1167-1344.p.]

- Szervezeti és szolgálati utasitás a Magyar Királyi Csendőrség számára. Budapest, 1900, Pesti Kőnyomda. 361 p.

- Utasitások a Magyar Királyi Csendörség számára. Budapest, 1912, Várnay és Fia „Municipia” Kiadóhivatala. 360 p. és 384 p.

- Szolgálati utasitás a Magyar Királyi Csendőrség számára. (Tervezet) Budapest, 1924, Pallas. 292 p.

- Szervezeti és szolgálati utasitás a Magyar Királyi Csendőrség számára. Budapest, 1927, Pallas. 411 p.

- Szervezeti és szolgálati utasitás a Magyar Királyi Csendőrség számára. Budapest, 1941, Stádium. 411 p.

- 1222/XI.tc. vendégek avagy idegenek mi módon jussanak méltóságra.

1222/XIX.tc. a föld népe és a vendégek szabadságáról.

- $\quad 1405 /$ II.tc. milyen módon szabad az idegen kereskedőknek az országon belül posztót árulni.

1405/XVI.tc. azok büntetése a kik külföldi vagy idegen kereskedők portékáit saját portékáik gyanánt maguknál tartják és árulják.

1439/V.tc. hogy külföldiekre tisztségek nem ruházhatók és hogy a föpapok és báró urak ne tartsanak maguknak idegen embereket.

- 1453/III.tc. a király méltóságokat külföldiekre ne ruházzon.

1492/IX.tc. a birtokjogok nem idegeneknek, hanem magyaroknak adományozandók.

1492/LXXXIV.tc. a külföldi és idegen kereskedők vásárlásra és csereberélésre a kijelölt szokott helyekre menjenek.

1495/XXX.tc. Külföldiek részére nem szabad egyházi javadalmakat adományozni; az adományozottakat, ha az illetők felhivatván, nem jönnek be, hogy ott lakjanak, el kell tölük venni.

- 1495/XXXI.tc. a külföldiek mástól, mint a királytól vagy másoktól, mint a kiknek ebben az országban kegyúri joguk van, kérnek föl egyházi javadalmakat, vízbe kell őket fullasztani.

- 1498/XXX.tc. hogy a vámszedők magyarok legyenek és ne külföldiek. 
1498/LVI.tc.

1525/IV.tc.

1563/XXXIV.tc.

1600/XXVIII.tc. (20.;)

1601/XXVI.tc.

1609/XI.tc.

1622/II.tc.

1625/XXIV.tc.

1647/LXV.tc.

1655/XIX.tc.

1715/XCIX.tc.

(24.;)

1871/XVIII.tc.

(43., 66., 67., 193.;)

1876/V.tc.

(44., 68., 193.;)

1877/XX.tc.

(29.;)

1878/V.tc.

(76.;)

1879/XXVIII.tc.

(78., 79.;)

1879/XL.tc.

(70., 77., 88.;)

1879/L.tc.

(38., 41., 45., 51., 105., 109., 194.;)

1881/III.tc.

(195.;)

1881/XXI.tc.

(123.;)

1886/IV.tc.

(42.;)

1886/XXII.tc.

(46., 48., 69., 107., 193.;)

1894/XXXIII.tc.

(86.;)

1903/IV.tc.

(28., 59., 197.;)
1498/LVI.tc. egy egyházi személy se lehessen két javadalomnak vagy két méltóságnak a birtokában vagy élvezetében; továbbá, azok a javadalmak, melyek a római curiánál vannak valaki részére lekötve, egy év alatt szabaddá teendők; és külföldiek részére nem kell egyházi javadalmakat adományozni

1525/IV.tc. az idegen nemzetböl való tisztek elmozdítandók s magyarokkal helyettesítendők, a lutheránusokat meg kell égetni.

1563/XXXIV.tc. az idegen kapitányoknak és más előljáróknak az országból kiküldése.

1600/XXVIII.tc. arról, hogy Magyarországon és Szlavóniában idegen katonákat ne fogadjanak, hadi szemle alá ne vegyenek és ne szabadságoljanak.

1601/XXVI.tc. Magyarországon és Szlavóniában az idegen katonák besorozásának, szemle elé állitásának és elbocsátásának a tilalmára, úgy a katonák elszállásolására és erőszakoskodásaikra és más sérelmekre nézve, az országlakók a korábbi évek törvénycikkelyeinek a megtartását határozzák el.

- 1609/XI.tc. az országlakók mentegetődzése az irányban, hogy Magyarországból az idegen nemzetbelieket végképen ki nem zárták.

- 1622/II.tc. a szentséges császári és királyi felségtől, az ország karai és rendei részéről, az õ szerencsés felavatása alkalmából kiadott hitlevélnek az ország közönséges végzései közé iktatása.

- 1625/XXIV.tc. az ország véghelyein az idegen katonák megtüréséröl.

1647/LXV.tc. idegen katonáknak az ország végvidékeire való bebocsátásáról, és arról, hogy bennszületett katonákat a határszélekről az országon kívül ne vigyék.

- 1655/XIX.tc. az idegen katonaságot három év alatt ki kell vinni és az ország beleegyezése nélkül nem szabad behozni.

1715/XCIX.tc. a halasztó és eltiltó parancsokról.

1871/XVIII.tc. a községek rendezéséröl.

1876/V.tc. a községek rendezéséről szóló 1871/XVIII.tc. módosításáról és kiegészítéséről.

1877/XX.tc. a gyámsági és gondnoksági ügyek rendezéséről.

1878/V.tc. a magyar büntetőtörvénykönyv a büntettekröl és vétségekröl.

1879/XXVIII.tc. a rendőri bejelentési intézménynek Budapest fövárosban életbeléptetéséröl.

1879/XL.tc. a magyar büntető törvénykönyv a kihágásokról.

1879/L.tc. a magyar állampolgárság megszerzéséről és elvesztéséröl.

1881/III.tc. a közbiztonsági szolgálat szervezéséről.

1881/XXI.tc. a Budapest-fővárosi rendőrségröl.

1886/IV.tc. a tömegesen visszatelepülők honosításáról.

1886/XXII.tc. a községekröl.

1894/XXXIII.tc. az állami anyakönyvekröl.

1903/IV.tc. a kivándorlásról. 
1903/V.tc.

(42., 59., 75., 83., 87., 92., 95.,

103., 117., 125.,130., 137., 166.,

197.;)

1903/VI.tc.

(101., 197.;)

1903/VIII.tc.

(59., 129., 175., 198.;)

1908/XXXVI.tc.

(34.;)

1909/II.tc.

(28.;)

1912/LXIII.tc.

(90.;)

1913/XXI.tc.

(74., 153.;)

1915/XIX.tc.

(141.;)

1916/IV.tc.

(136.,)

1920/XXV.tc.

(138.;)

1921/III.tc.

(139.,

1921/XXXIII.tc.

(42., 104., 199.;)

1922/XXVI.tc.

(142.;)

1925/XIX.tc.

(36.;)

1930/XXVIII.tc.

(126.,129.,131.;)

1939/XIII.tc.

(50., 203.;)

1993/LXXXVI.tv.

(84.;)

584/1880. (I. 5.) BM.r.

(41.;)

38 547/1880. (VIII. 17.) BM.kr. (26.;)

9 389/1885. (II. 14.) BM.r.

(71.;)

29 601/1886. (XI. 23.) IM.r.

(99.;)

54 091/1888. (VIII. 11.) BM.r. $(80 . ;)$
1903/V.tc. külföldieknek a magyar korona országai területén való lakhatásáról.

1903/VI.tc. az útlevélügyröl.

1903/VIII.tc. a határrendőrségröl.

1908/XXXVI.tc. a büntetőtörvénykönyvek és a bünvádi perrendtartás kiegészítéséről és módosításáról

1909/II.tc. a kivándorlásról.

1912/LXIII.tc. a háború esetére szóló kivételes intézkedésekről.

1913/XXI.tc. a közveszélyes munkakerülökröl.

1915/XIX.tc. a hadviselés érdekei ellen elkövetett büncselekmények, különösen a hadi szállítások körül elkövetett visszaélések megtorlásáról.

1916/IV.tc. a háború esetére szóló kivételes intézkedésekről alkotott törvények újabb kiegészítéséröl.

- 1920/XXV.tc. a vagyon, az erkölcsiség és a személyiség hatékonyabb büntetőjogi védelméröl.

- 1921/III.tc. az állami és a társadalmi rend hatályosabb védelméröl.

1921/XXXIII.tc. az Északamerikai Egyesült Államokkal, a Brit Birodalommal, Franciaországgal, Olaszországgal és Japánnal, továbbá Belgiummal, Kínával, Kubával, Görögországgal, Nikaraguával, Panamával, Lengyelországgal, Portugáliával, Romániával, a SzerbHorvát-Szlovén Állammal, Sziámmal és Cseh-Szlovákországgal 1920. évi június hó 4. napján a Trianonban kötött békeszerződés becikkelyezéséről.

— 1922/XXVI.tc. a fizetési eszközökkel elkövetett visszaélésekröl.

- 1925/XIX.tc. a nőkkel és a gyermekekkel üzött kereskedés elnyomása végett Genfben létrejött nemzetközi egyezmény becikkelyezése tárgyában.

- 1930/XXVIII.tc. a külföldieknek a Magyar Szent Korona országai területén lakhatásáról szóló 1903/V.tc. egyes rendelkezéseinek módosításáról.

1939/XIII.tc. a magyar állampolgárság megszerzéséről és elvesztéséröl szóló 1879/L.tc. kiegészítéséről és módosításáról.

— 1993/LXXXVI.tv. a külföldiek beutazásáról, magyarországi tartózkodásáról és bevándorlásáról.

- 584/1880. (I. 5.) BM.r. a magyar állampolgárság megszerzéséről és elvesztéséről szóló 1879. évi L. tc. végrehajtása tárgyában.

Magyarországi Rendeletek Tára, XIV.évf. (1880) 1. sz. 3-8.p.

38 547/1880. (VIII. 17.) BM.kr. a magyar büntetö-törvénykönyvek végrehajtása tárgyában.

Magyarországi Rendeletek Tára, XIV.évf. (1880) 1. sz. 629-659.p.

- 9389/1885. (II. 14.) BM.r. azúj toloncz-szabályzat kibocsátása tárgyában. Magyarországi Rendeletek Tára, XIX.évf. (1885) 1. sz. 164-168.p.

29 601/1886. (XI. 23.) IM.r. az országból való kiutasításra ítélt külföldiek honossága és illetőség-helyének megállapítása és a kiutasítás végrehajtásánál a közigazgatási tolonchatóságok közbenjárásának igénybevételére

Magyarországi Rendeletek Tára, XX.évf. (1886) 1. sz. 998-999.p.

- 54 091/1888. (VIII. 11.) BM.r. külföldieknek a községekben való lakhatása tárgyában.

Magyarországi Rendeletek Tára, XXII.évf. (1888) 1. sz. 2499-2503.p 
50 431/1891. (VII. 15.) BM.r. (157., 196.;)

86 225/1895. (X. 29.) BM.r. $(150 . ;)$

100 122/1895. (XI. 16.) BM.r. (81.;)

117 121/1898. (XII. 9.) BM.r. (82.;)

71 000/1904. (VII. 18.) BM.r. $(169 . ;)$

71 500/1904. (VII. 26.) BM.r. $(169 . ;)$

90 000/1905. (IV. 13.) BM.kr. (166.;)

91 000/1905. (XII. 29.) BM.r. (176., 198.;)

29 807/1906. (VI. 16.) BM.kr (167.;)

34 283/1906. (V. 4.) BM.kr. (168.;)

54 975/1908. (IV. 30.) BM.r. (183.;)

129 405/1908. (X. 15.) BM.kr. (143.;)

57 000/1909. (VI. 15.) BM.kr. (160.;)

65 000/1909. (IX. 26.) BM.r. (93.;)

48 999/1912. (IV. 13.) BM.r. (159.;)

58 320/1912. (IV. 13.) BM.r. (159., 183.;)

5 047/1919. (X. 1.) ME.r. (120., 188.;)
50 431/1891. (VII. 15.) BM.r. az 1888. évi XIV. törvénycikkel becikkelyezett magyar-román határegyezmény alapján kiadott határörizeti utasítás tárgyában.

Magyarországi Rendeletek Tára, XV.évf. (1891) 1.sz. 879-884.p.

- 86 225/1895. (X. 29.) BM.r. az utóneveknek a születési anyakönyvekbe - a magyar mellett - idegen nyelven is bejegyezhetésére. Magyarországi Rendeletek Tára, XXIX.évf. (1895) 2. sz. 1397-1421.p.

100 122/1895. (XI. 16.) BM.r. külföldiek nyilvántartása tárgyában hozott szabályrendeletek életbe léptetése iránt.

Magyarországi Rendeletek Tára, XXIX.évf. (1895) 1. sz. 1429-1430.p.

117 121/1898. (XII. 9.) BM.r. a külföldieknek a községekben lakhatása ügyében kibocsátott rendelet pontos végrehajtására. Magyarországi Rendeletek Tára, XXXII.évf. (1898) 1. sz. 1188-1189.p

71 000/1904. (VII. 18.) BM.r. valamennyi törvényhatóságnak, a székesfővárosi államrendőrség főkapitányának és a fiumei kormányzónak, az útlevelekre, $\mathrm{s}$ a kivándorlásra és visszavándorlására vonatkozó statisztikai adatok szolgáltatása tárgyában Magyarországi Rendeletek Tára, XXXVIII.évf. (1904) 1. sz. 703-714.p.

71 500/1904. (VII. 26.) BM.r. Beszterce-Naszód, Brassó, Csik, Fogaras, Háromszék, Hunyad, Krassó-Szörény, Szeben, Temes és Torontál vármegyék, valamint Pancsova város közönségéhez, a határforgalom ellenőrzéséről, az útlevelek vizsgálatáról, az útiigazolványok kiállításáról és a forgalmi adatok gyüjtéséről szóló rendelet megküldése tárgyában

Magyarországi Rendeletek Tára, XXXVIII.évf. (1904) 1. sz. 716-725.p.

- 90 000/1905. (IV. 13.) BM.kr. a Külföldieknek a magyar korona országai területén lakhatásáról szóló 1903: V. t.-c. végrehajtása tárgyában.

Magyarországi Rendeletek Tára, XL.évf. (1906) 1. sz. 171-204.p.

91 000/1905. (XII. 29.) BM.r. valamennyi törvényhatósághoz Fiume város kivételével, a határrendőrségről szóló 1903:VIII. t.-cikk életbeléptetéséről és végrehajtásáról.

Magyarországi Rendeletek Tára, XXXIX.évf. (1905) 2. sz. 1455-1541.p.

29 807/1906. (VI. 16.) BM.kr. a gyártelepeken alkalmazott külföldiek nyilvántartásáról.

Magyarországi Rendeletek Tára, XL.évf. (1906) 1. sz. 622-623.p.

- 34 283/1906. (V. 4.) BM.kr. a külföldiek nyilvántartásáról fürdőtelepeken.

Magyarországi Rendeletek Tára, XL.évf. (1906) 1. sz. 609-610.p.

54 975/1908. (IV. 30.) BM.r. a határszéli örségek létesítéséröl. Belügyi Közlöny, XIII.évf. (1908) 19.sz. 209-210.p.

129 405/1908. (X. 15.) BM.kr. a m. kir. igazságügyminiszter által az 1878 : V. t.-c. 64. §-a alapján az országból kiutasításra ítélt külföldiekkel szemben követendő eljárás iránt 18.138/1908. sz. a. kiadott rendelet közzétételéröl.

Magyarországi Rendeletek Tára, XLII.évf. (1908) 1. sz. 1706-1709.p.

57 000/1909. (VI. 15.) BM.kr. valamennyi törvényhatósághoz és Budapest székesfőváros államrendőrsége fökapitányához, a kivándorlásról szóló 1909 : II. t.-c. életbeléptetéséről és végrehajtásáról. Magyarországi Rendeletek Tára, XLIII.évf. (1909) 1. sz. 1049-1098.p.

- 65 000/1909. (IX. 26.) BM.r. a rendőri büntetőeljárásra vonatkozó egységes szabályzat kibocsátásáról.

Magyarországi Rendeletek Tára, XLIII.évf (1909) 1. sz.1719-1837.p.

- 48 999/1912. (IV. 13.) BM.r. határszéli külszolgálat átvétele a m. kir. csendőrség által.

Belügyi Közlöny, XVII.évf. (1912) 18.sz. 141-145.p.

58 320/1912. (IV. 13.) BM.r. A határrendőri külszolgálat ellátása a határrendőri őrségek megszüntetésével. Belügyi Közlöny, XVII.évf. (1912) 18.sz.136-140.p.

- $\quad 5$ 047/1919. (X. 1.) ME.r. a rendőrség államosításáról. Magyarországi Rendeletek Tára, LIII.évf. (1919) I.füzet. 752-767.p. 
3 240/1920. (IV. 19) ME.r. (110.;)

8 352/1920. (X. 27.) ME.r. (112.;)

684/1921. (II. 1.) ME.r.

(113.;)

6 500/1921. (IX. 28.) ME.r. (104.;)

69 500/1921. (IX. 30.) BM.kr. (104.;)

84 143/1921. (X. 7.) BM.r. (104.;)

5 645/1923. (VI. 4.) BM.r. (178.;)

2 344/1924. (III. 28.) ME.r (114.;)

81 000/1924. (V. 20.) BM.kr. (152.;)

200 000/1925. (IV. 25.) BM.r. (115., 118., 119., 201.;)

12 551/1926. (III. 15.) BM.r. (108.;)

101 000/1927. (I. 6.) BM.r. (119.;)

7 270/1930. (XI. 20.) ME.r. (121., 202.;)

63 410/1930. (XII. 16.) BM.r. (122., 202.;)

100 000/1930. (XI. 6.) BM.r. (127.,132., 202.;)

6 500/1931. (XI. 30.) ME.r. (190.;)

83 383/1898. (I. 1.) BM.elvi.hat. (73.;)

4 352/1920. (III. 27.) BM.int. (134.;)
3 240/1920. (IV. 19.) ME.r. az Országos Menekültügyi Hivatal létrehozásáról.

Budapesti Közlöny, LIII.évf. (1920) 91.sz. 89.p.

8 352/1920. (X. 27.) ME.r. a megszállott területekröl beutazók ellenörzéséröl.

Belügyi Közlöny, XXV.évf. (1920) 48.sz. 1853.p.

684/1921. (II. 1.) ME.r. a megszállott területekről beutazók ellenörzéséről szóló 8352/1920. ME.r. végrehajtása tárgyában.

Belügyi Közlöny, XXVI.évf. (1921) 7.sz. 168-171.p.

- 6 500/1921. (IX. 28.) ME.r. a trianoni békeszerződésben foglalt állampolgársági rendelkezések ismertetése és végrehajtása tárgyában. Belügyi Közlöny, XXVI.évf. (1921) 41.sz. 1908-1915.p.

- 69 500/1921. (IX. 30.) BM.kr. utasítás a trianoni békeszerződésben foglalt állampolgársági rendelkezések ismertetése és végrehajtása tárgyában kelt 6500/1921.ME. rendelethez.

Magyarországi rendeletek Tára, LV.évf. (1921) 1.sz. 575-576.p.

- $\quad 84$ 143/1921. (X. 7.) BM.r. a trianoni békeszerződésben foglalt állampolgársági rendelkezések tárgyában kiadott 69 500/1921.BM. körrendeleti utasítás kiegészítéséről. Magyarországi rendeletek Tára, LV.évf. (1921) 1.sz. 578-579.p.

— $5645 / 1923$. (VI. 4.) BM.r. a határátlépő állomások kijelöléséről és az ott szervezett $\mathrm{m}$. kir. állami rendőrségi kirendeltségek hatásköréröl. Belügyi Közlöny, XXVIII.évf. (1923) 29.sz. 1114-1118.p.

- $\quad 2$ 344/1924. (III. 28.) ME.r. az Országos Menekültügyi Hivatal megszüntetéséröl. Belügyi Közlöny, XXIX.évf. (1924) 27.sz. 682.p.

— $\quad 81$ 000/1924. (V. 20.) BM.kr. a könyöradomány-gyüjtés (koldulás) szabályozásáról. Magyarországi Rendeletek Tára, LVIII.évf. (1924) 1.sz. 399-401.

- $\quad 200$ 000/1925. (IV. 25.) BM.r. külföldieknek az ország területén lakhatásáról szóló 1903 : V. t.-c. végrehajtásáról.

Magyarországi Rendeletek Tára, LIX.évf. (1925) 1.sz. 179-195.p.

- 12 551/1926. (III. 15.) BM.r. a visszahonosítási kérelmek tárgyalásának egyszerüsítéséről és gyorsításáról.

Magyarországi Rendeletek Tára, LX.évf. (1926) 1.sz. 264-266.p.

- $\quad 101$ 000/1927. (I. 6.) BM.r. a külföldiek tartózkodási engedélyéröl. Magyarországi Rendeletek Tára, LX.évf. (1927) 1.sz. 165-166.p.

- $\quad 7$ 270/1930. (XI. 20.) ME.r. a bejelentési kötelezettségnek az ország egész területére kiterjesztése tárgyában.

Belügyi Közlöny, XXXV.évf. (1930) 54.sz. 1027.p.

- 63 410/1930. (XII. 16.) BM.r. a bejelentés kötelezettségének az ország egész területére kiterjesztéséről szóló rendelet végrehajtására. Belügyi Közlöny, XXXV.évf. (1930) 58.sz. 1091-1092.p.

— $\quad 100$ 000/1930. (XI. 6.) BM.r. külföldieknek a Magyar Szent Korona országai területén lakhatásáról szóló 1903/V.tc., illetve ennek módosításáról szóló 1930/XXVIII.tc. végrehajtása tárgyában.

Belügyi Közlöny, XXV.évf. (1930) 57.sz. 1078-1086.p.

- 6 500/1931. (XI. 30.) ME.r. a rendőrség szervezeti változásairól. Magyarországi Rendeletek Tára, LXV.évf. (1931) XII.füzet. 1533-1534.p.

83 383/1898. (I. 1.) BM.elvi.hat.

Közigazgatási elvi határozatok egyetemes gyüjteménye. Új Folyam. I.köt. Budapest, 1906, Pallas. 443.p.

- 4 352/1920. (III. 27.) BM.int. az állam biztonságára vagy a társadalmi rend és béke szempontjából, valamint a közbiztonságra veszélyes, aggályos és gyanús, úgyszintén gazdasági okokból káros egyének rendőri felügyelet alá helyezése, őrizetbe vétele és internálása. Belügyi Közlöny, XXV.évf. (1920) 16.sz. 570-578.p. 